\title{
COBRANÇA SOBRE USOS DA ÁGUA COMO INSTRUMENTO ECONÔMICO DE GESTÃO: O CASO DO RESERVATÓRIO DE SALTO GRANDE (AMERICANA, SP).
}

\section{Carlos Alberto Perdigão Pessoa}

Dissertação apresentada à Escola de Engenharia de São Carlos da Universidade de São Paulo, como parte dos requisitos para obtenção do título de Mestre em Hidráulica e Saneamento.

ORIENTADOR: Prof. Titular Marcelo Pereira de Souza

São Carlos

2002 


\section{AGRADECIMENTOS}

Aos meus pais Antônio e Lúcia, pelo amor, dedicação, incentivo e educação.

Ao meu irmão Delano, pelo apoio e camaradagem.

À minha Gláucia, pelo amor, carinho, compreensão e incentivo demonstrados durante o período de ausência necessário à realização deste trabalho.

Ao Prof. Titular Marcelo Pereira de Souza, pela orientação, dedicação, amizade e confiança. Estes, com certeza, foram requisitos fundamentais para realização deste trabalho, que me proporcionou a oportunidade crescimento pessoal e profissional.

Aos professores Rodrigo, Fazal, Fernanda, Swami e Ruth, do SHS/EESC/USP, pelos ensinamentos e troca de experiências profissionais.

Aos amigos Tibério, Fábio, Iran, Everton e João Fernando, pelo estímulo inicial à realização deste Mestrado, amizade e companheirismo.

Aos amigos Fernando, Sergio Brasil, Sergio Luís, Holden, Helano, Adeildo, Nájila, Vinícios, Jorge, André Shuster, Leonardo Soares, Andrezão, Aurélio, Hélio, Giovanni, Márcio Nemer, André Coelho, João Fernandes, João Rodrigo e outros, pelo apoio durante a realização deste trabalho.

Aos colegas da turma de 2000 do curso de Pós-Graduação em Hidráulica e Saneamento e do Laboratório de Sistema de Informação Geográfica (Aurélio, Isabel, Victor, Marcelo e William) que de alguma maneira contribuíram para execução deste trabalho, pela amizade e espírito de equipe demonstrado ao longo deste período.

Às funcionárias do SHS (Sá, Pavlovna e Rose), pela atenção prestada.

Ao Conselho Nacional de Desenvolvimento Científico e Tecnológico - CNPq, pela bolsa de estudo concedida. 


\section{SUMÁRIO}

LISTA DE FIGURAS............................................................................................

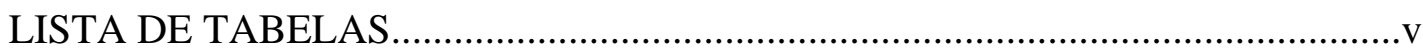

LISTA DE SIGLAS E ABREVIATURAS...............................................................viii

LISTA DE SÍMBOLOS.....................................................................................

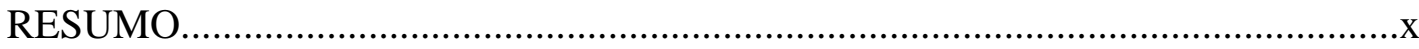

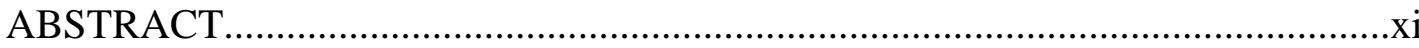

1. Introdução.......................................................................................................................... 1

2. Objetivos .............................................................................................................................. 6

3. Gestão ambiental e gestão das águas....................................................................... 7

3.1 Instrumentos econômicos de gestão das águas .................................................. 12

3.1.1 Contextualização dos instrumentos econômicos........................................ 12

3.1.2 Tipos de instrumentos econômicos ........................................................... 16

3.1.2.1 Taxas e Tarifas ............................................................................... 16

3.1.2.2 Subsídios ...................................................................................... 19

3.1.2.3 Sistemas de devolução de depósitos ................................................. 20

3.1.2.4 Mercado de direitos de poluição ........................................................ 20

3.1.2.5 Mercado de direitos de uso ................................................................... 21

\section{Algumas experiências internacionais em gestão das águas e os instrumentos} econômicos........................................................................................................................ 23

4.1 Caso da França .................................................................................................. 23

4.1.1 Formação do valor cobrado na França .................................................... 29

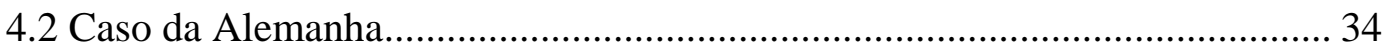

4.2.1 Formação do valor cobrado na Alemanha ................................................ 38

4.2.1.1 Cobrança sobre captação.................................................................. 38

4.2.1.2 Cobrança sobre lançamento de efluentes ........................................... 39

4.3 Caso da Inglaterra e do País de Gales ............................................................. 42

4.3.1 Histórico ................................................................................................ 42

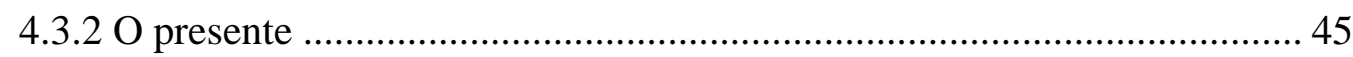

4.3.3 Formação do valor cobrado na Inglaterra e País de Gales ........................ 47

4.3.3.1 Cobrança sobre captação..................................................................... 47

4.3.3.2 Cobrança sobre lançamento de efluentes ........................................... 51 


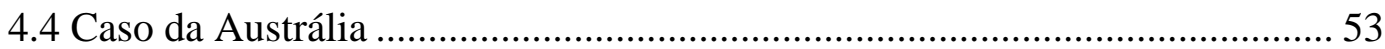

4.4.1 Formação do valor cobrado na Austrália ............................................... 56

4.4.1.1 Cobrança sobre captação............................................................. 56

4.4.2 Funcionamento do mercado de direitos de uso da água na Austrália ...... 58

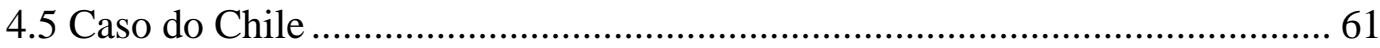

4.5.1 Funcionamento do mercado de direitos de uso da água no Chile............ 65

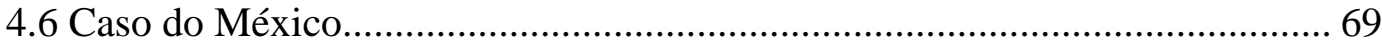

4.6.1 Formação do valor cobrado no México ................................................... 74

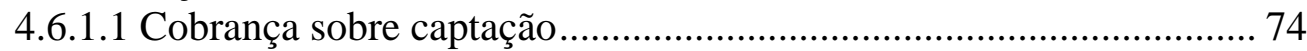

4.6.1.2 Cobrança sobre lançamento de efluentes ........................................ 77

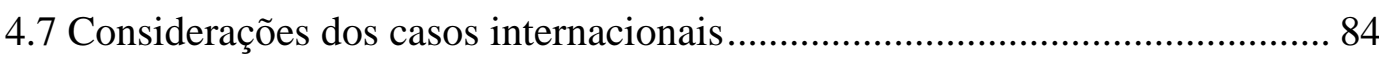

\section{Duas experiências brasileiras em gestão das águas e os instrumentos}

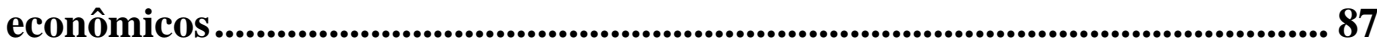

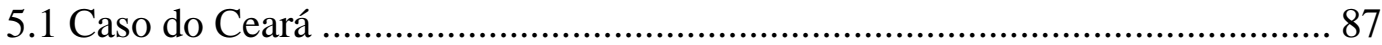

5.1.1 Formação do valor cobrado no Ceará .................................................... 91

5.2 Caso de São Paulo................................................................................................. 94

5.2.1 Proposta de formação do valor a ser cobrado em São Paulo .................... 98

5.3 Considerações dos casos nacionais .............................................................. 102

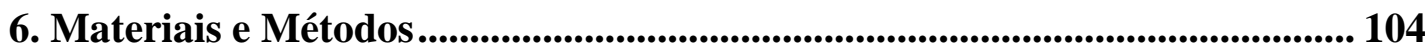

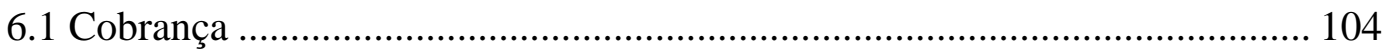

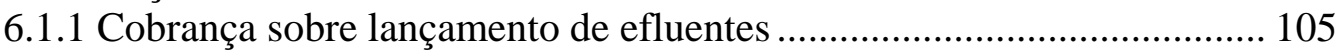

6.1.2 Cobrança sobre consumo de água ..................................................... 107

7. Estudo de Caso: reservatório de Salto Grande (Americana, SP) ................... 110

7.1 Bacia do rio Atibaia e o reservatório de Salto Grande.................................. 110

7.2 Aplicação da cobrança sobre usos da água no reservatório de Salto Grande 116

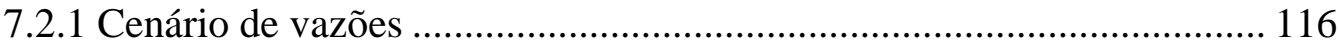

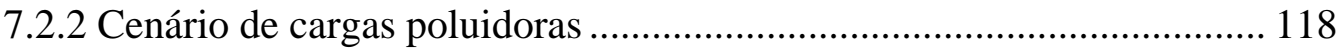

7.2.3 Cobrança sobre captação para abastecimento da cidade de Sumaré...... 123

7.2.4 Cobrança sobre captação do setor agropecuário .................................... 128

7.2.5 Cobrança sobre lançamento de efluentes da cidade de Paulínia............. 132

7.2.6 Cobrança sobre uso da água para geração de energia elétrica ............... 137

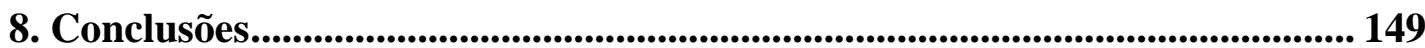

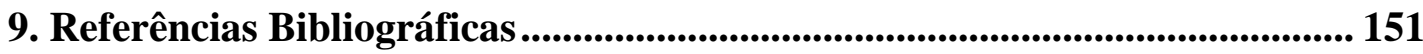




\section{LISTA DE FIGURAS}

FIGURA 01 - Organograma do sistema chileno de gestão das águas......................63 63

FIGURA 02 - Bacias hidrográficas componentes da 5a UGRHI .......................... 114

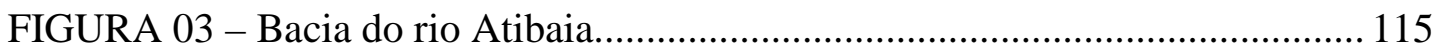

FIGURA 04 - Gráfico de vazões médias mensais afluentes ao reservatório de Salto

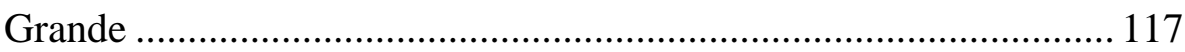

FIGURA 05 - Banco de macrófitas no reservatório de Salto Grande (2001) ......... 120

FIGURA 06 - Tomadas de água de Salto Grande para geração de energia (2001). 138

FIGURA 07 - Usina Hidroelétrica de Americana (2001) ....................................... 138

FIGURA 08 - Gráfico de vazões médias mensais afluentes e efluentes ao reservatório de Salto Grande. ........................................................... 143 


\section{LISTA DE TABELAS}

TABELA 01 - Coeficientes de zona (CZ) para cada bacia (1994).......................... 31

TABELA 02 - Coeficientes de aglomeração (K) de acordo com a população ......... 31

TABELA 03 - Coeficientes de coleta (CC) para cada bacia (1994) ......................... 31

TABELA 04 - Poluentes e respectivas unidades de poluição .................................... 40

TABELA 05 - Valores da cobrança unitária padrão (SUC) por região ...................... 50

TABELA 06 - Coeficiente em função do volume de efluentes lançados “CV” ....... 52

TABELA 07 - Coeficiente em função do tipo de efluente “CE” ................................ 52

TABELA 08 - Valores cobrados de acordo com zonas de disponibilidade de água. 75

TABELA 09 - Valores cobrados sobre captação de água para abastecimento urbano

TABELA 10 - Valor cobrado sobre uso da água para geração de energia elétrica... 75

TABELA 11 - Valores cobrados sobre captação de água para aqüicultura ............... 75

TABELA 12 - Valores cobrados sobre uso da água em balneários e centros

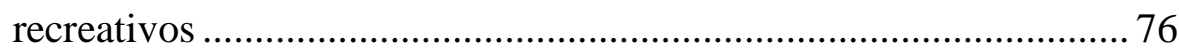

TABELA 13 - Limites máximos de concentração estabelecidos como padrão de

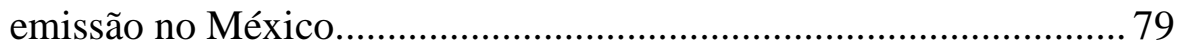

TABELA 14 - Valores cobrados de acordo as faixas de pH do efluente lançado..... 80

TABELA 15 - Valores unitários de cobrança de acordo com INC ............................ 82

TABELA 16 - Preços Unitários Básicos e Máximos ............................................... 100

TABELA 17 - Curvas de custos totais de sistemas de tratamento de efluentes...... 109

TABELA 18 - Coeficientes multiplicadores de acordo com o tipo tratamento ....... 110

TABELA 19 - Características do reservatório de Salto Grande............................... 111

TABELA 20 - Uso e ocupação do solo na bacia do rio Atibaia............................... 114

TABELA 21 - Vazões médias mensais afluentes ao reservatório de Salto Grande 118

TABELA 22 - Disponibilidade hídrica superficial na bacia do rio Atibaia ............ 118

TABELA 23 - Parâmetros de qualidade da água do rio Atibaia em 2000 ............... 119

TABELA 24 - Estações de tratamento de esgoto propostas ou em obras ................ 121 
TABELA 25 - Cargas poluidoras pontuais potenciais e remanescentes no trecho do rio Atibaia, desde a confluência do ribeirão Anhumas até o início da bacia hidráulica da represa de Salto Grande em 2000 122

TABELA 26 - Cargas poluidoras pontuais potenciais e remanescentes no trecho do rio Atibaia, desde a confluência do ribeirão Anhumas até o início da bacia hidráulica da represa de Salto Grande em 2005

TABELA 27 - Cargas poluidoras pontuais potenciais e remanescentes no trecho do rio Atibaia, desde a confluência do ribeirão Anhumas até o início da bacia hidráulica da represa de Salto Grande em 2010

TABELA 28 - Projeções demográficas e demandas de água para cidade de Sumaré

TABELA 29 - Cobrança sobre captação no reservatório de Salto Grande para abastecimento da cidade de Sumaré em 2000.

TABELA 30 - Cobrança sobre captação no reservatório de Salto Grande para abastecimento da cidade de Sumaré em 2005.

TABELA 31 - Cobrança sobre captação no reservatório de Salto Grande para abastecimento da cidade de Sumaré em 2010.

TABELA 32 - Demandas de água em Salto Grande para o setor agropecuário

TABELA 33 - Cobrança sobre captação no reservatório de Salto Grande para atendimento ao setor agropecuário em 2000.

TABELA 34 - Cobrança sobre captação no reservatório de Salto Grande para atendimento ao setor agropecuário em 2005

TABELA 35 - Cobrança sobre captação no reservatório de Salto Grande para atendimento ao setor agropecuário em 2010.

TABELA 36 - Projeção das cargas poluidoras remanescentes da cidade de Paulínia 133

TABELA 37 - Cobrança sobre o lançamento de efluentes líquidos de origem doméstica da cidade de Paulínia em 2000

TABELA 38 - Cobrança sobre lançamento de efluentes líquidos de origem doméstica da cidade de Paulínia em 2005

TABELA 39 - Cobrança sobre lançamento de efluentes líquidos de origem doméstica da cidade de Paulínia em 2010 
TABELA 40 - Vazões médias mensais afluentes e efluentes ao reservatório de Salto Grande.......

TABELA 41 - Cobrança sobre uso da água para geração de energia elétrica no reservatório de Salto Grande em 2000

TABELA 42 - Cobrança sobre uso da água para geração de energia elétrica no reservatório de Salto Grande em 2005. 146

TABELA 43 - Cobrança sobre uso da água para geração de energia elétrica no reservatório de Salto Grande em 2010 


\section{LISTA DE ABREVIATURAS E SIGLAS}

$\begin{array}{ll}\text { ANA } & \text { - Agência Nacional de Águas } \\ \text { ANEEL } & \text { - Agência Nacional de Energia Elétrica } \\ \text { CAGECE } & \text { - Companhia de Água e Esgoto do Ceará } \\ \text { CBHs } & \text { - Comitês de Bacias Hidrográficas } \\ \text { CNA } & \text { - Comissão Nacional da Água } \\ \text { COAG } & \text { - Council of Australian Governments } \\ \text { COGERH } & \text { - Companhia de Gestão de Recursos Hídricos } \\ \text { CORHI } & \text { - Comitê Coordenador do Plano Estadual de Recursos Hídricos } \\ \text { CRH } & \text { - Conselho Estadual de Recursos Hídricos } \\ \text { DAEE } & \text { - Departamento de Águas e Energia Elétrica } \\ \text { DBO } & \text { - Demanda Bioquímica de Oxigênio } \\ \text { DETR } & \text { - Department of the Environment, Transport and the Regions } \\ \text { DGA } & \text { - Direção Geral de Águas } \\ \text { DLWC } & \text { - Department of Land and Water Conservation } \\ \text { DWI } & \text { - Drinking Water Inspectorate } \\ \text { EA } & \text { - Environment Agency } \\ \text { FEHIDRO } & \text { - Fundo Estadual de Recursos Hídricos } \\ \text { IEs } & \text { - Instrumentos Econômicos } \\ \text { IPART } & \text { - Independent Pricing and Regulatory Tribunal } \\ \text { NRA } & \text { - National Rivers Authority } \\ \text { OCDE } & \text { - Organização para Cooperação e Desenvolvimento Econômico } \\ \text { OFWAT } & \text { - Office of Water Services } \\ \text { RWA } & \text { - Regional Water Authorities } \\ \text { SIGRH } & \text { - Sistema Integrado de Gerenciamento de Recursos Hídricos } \\ \text { SABESP } & \text { - Companhia de Saneamento Básico do Estado de São Paulo } \\ \text { SUC } & \text { - Standard Unit Charge } \\ \text { UGRHI } & \text { - Unidades Hidrográficas de Gerenciamento de Recursos Hídricos } \\ \text { CAn } & \end{array}$




\section{LISTA DE SÍMBOLOS}

c $\quad$ - padrão de qualidade (mg/L).

ce - concentração do poluente no efluente final (mg/L).

cp - concentração máxima permitida pelo padrão de emissão (mg/L).

Cs - carga de saturação do corpo de água (mg/s).

Ic - índice de carga.

Kc - coeficiente multiplicador (US\$/mês)/(L/s).

K - coeficiente multiplicador da situação anterior à captação (US\$/mês)/(L/s).

$\mathrm{K}_{2}$ - coeficiente multiplicador da situação posterior à captação (US\$/mês)/(L/s).

Q - vazão do corpo receptor, destinada à diluição e depuração de efluentes (L/s).

Qcon - vazão consumida (L/s).

Qe - vazão do efluente final (L/s).

S - fator ponderador da sazonalidade e tipo de atividade, para cobrança sobre captação.

$\sum \mathrm{Ce}$ - somatório das cargas poluidoras remanescentes, emitidas no corpo receptor à montante do ponto de lançamento, considerando a sua depuração (mg/s).

Te - cobrança sobre lançamento de efluentes (US\$/mês).

U - fator ponderador da sazonalidade, do tipo de usuário e da eficiência econômica do tratamento, para cobrança sobre lançamento de efluentes.

Tc - cobrança sobre consumo de água (US\$/mês). 


\section{RESUMO}

PESSOA, C. A. P. (2002). Cobrança sobre usos da água como instrumento econômico de gestão: o caso do reservatório de Salto Grande (Americana, SP). São Carlos, 2002. 158p. Dissertação (Mestrado). Escola de Engenharia de São Carlos, Universidade de São Paulo.

O presente trabalho contribui para a discussão e aplicação dos Instrumentos Econômicos (IEs) na gestão dos recursos hídricos, em especial a cobrança sobre usos da água, consideradas suas distintas possibilidades de implementação e metodologias aplicáveis. Foram analisadas algumas experiências internacionais e brasileiras no trato com os IEs e identificados os objetivos da utilização desses instrumentos nos respectivos sistemas de gestão. Essa análise revelou que, em determinados casos, a atuação dos IEs é descaracterizada pois não é atendido o objetivo precípuo desses instrumentos, qual seja, o incentivo ao uso adequado dos recursos hídricos. Para ilustrar a aplicação da cobrança sobre usos da água como instrumento econômico de gestão é utilizada a metodologia de SOUZA (1995). Foram realizadas simulações no reservatório de Salto Grande (Americana, SP) para os seguintes anos: 2000, 2005 e 2010. Os resultados indicam que a sazonalidade e os investimentos previstos para o controle de descargas poluentes influenciam, de maneira significativa, os valores cobrados nos cenários simulados.

Palavras-chave: instrumentos econômicos; cobrança sobre usos da água. 


\begin{abstract}
PESSOA, C. A. P. (2002). Water charges as management economic instrument: case of Salto Grande reservoir (Americana, SP). São Carlos, 2002. 158p. Dissertação (Mestrado). Escola de Engenharia de São Carlos, Universidade de São Paulo.

The present work contributes to the discussion and application of economic instruments (EIs) for water management, especially water charging, considering their different implementation possibilities and applicable methodologies. Some international and Brazilian experiences about EIs were analyzed and identified the objectives of the use of these instruments at their respective water management systems. This analysis shows that, in some cases, the EIs loose its real features because the main objective of the instruments - the incentive of sustainable water use - is not satisfied. The work shows an application of water charges as management economic instrument, based on SOUZA (1995). Simulations were made in Salto Grande reservoir (Americana, SP) for the years 2000, 2005 and 2010. The results indicate that sazonability and foreseen investments for the pollutant discharge control are of great influence the charged value on the simulated scenarios.
\end{abstract}

Key words: economics instruments; water charges. 


\section{Introdução}

Uma das causas da problemática ambiental pode ser encontrada no estilo de desenvolvimento que não articula corretamente os objetivos e restrições ambientais às demais metas do desenvolvimento. Em muitas situações verifica-se a falta de compatibilidade entre interesses privados e sociais; e entre os interesses de gerações presentes e futuras. (SACHS, 1993)

Portanto, a adoção de determinados modelos de desenvolvimento pode ser uma das causas dos desequilíbrios ambientais, os quais estão diretamente relacionados à disseminação da poluição e à escassez de recursos naturais - processos que trazem embutidos elevados custos à sociedade.

Neste contexto, SOUZA (1995) comenta que os desarranjos sociais brasileiros são resultado de um processo histórico de desenvolvimento mal planejado e tornamse cada vez mais preocupantes, pois a corrente econômica dominante é amplamente baseada em modelos econômicos neoclássicos, ou seja, em modelagem econômica preconizadora do livre mercado como forma de maximização dos benefícios sociais, que acredita na existência de suprimentos ilimitados dos recursos naturais e de lugares para dispor os resíduos resultantes dos usos desses recursos.

Percebe-se que o emprego de modelos, que causam aumento na demanda por recursos naturais, provoca questionamentos em relação à sustentabilidade conjunta dos processos econômicos e ambientais. Portanto, cabe observar a necessidade de se incorporar a questão ambiental aos processos de desenvolvimento, pressupondo que o ambiente seja uma de suas dimensões, e que deva ser internalizado em todos os níveis de decisão. É necessário apostar na redefinição dos objetivos e modalidades de ação, com as quais seja possível promover o desenvolvimento econômico e social contínuo, harmonizado à gestão racional do meio ambiente. (SACHS, 1986)

Atualmente, verifica-se que os processos de desenvolvimento visam a busca da sustentabilidade. Portanto, reconhecem os limites do ambiente natural, traduzidos na 
capacidade de suportar a carga imposta pelo funcionamento das relações sociais e econômicas. A escassez ou não dos recursos naturais é sinônimo dessa capacidade, e seus estágios podem determinar o valor econômico do recurso disponível.

Segundo SOUZA (1995), sem a incorporação dos valores sociais e dos preços dos recursos naturais, há distorção na real composição dos preços finais de uma série de produtos ou serviços, pois eles não observam as externalidades* negativas que ocasionam. Neste contexto, a água surge como recurso natural que deve ser dotado de valor econômico, pois seu uso é feito de maneira dispendiosa e sua capacidade de assimilação é finita.

Desta forma, a escassez das águas tem sido tema de estudos e principal objeto na elaboração e emprego de metodologias que visam a subsidiar sistemas de gestão de recursos hídricos. Este retrato situacional é diferente daquele de 50 anos, quando a oferta de água era o principal objetivo do planejamento e administração dos sistemas hídricos.

Acerca dessa realidade, AZEVEDO et al. (2000) comentam que muitos países, entre eles o Brasil, ao longo de sua história, percebiam a água como bem gratuito. $\mathrm{Na}$ prática, isso induziu a orientação do gerenciamento dos recursos hídricos para a ampliação da oferta, que possui forte apelo e visibilidade políticos. Contudo, a gestão da demanda e a recuperação de custos receberam pouca atenção.

Hoje, a gestão da escassez e da demanda dos recursos hídricos é necessidade premente. Neste contexto, percebe-se que os princípios e objetivos das políticas públicas já reconhecem a importância do gerenciamento da demanda, que é posto em operação por meio de instrumentos constituídos pela própria política. Dentre esses instrumentos encontram-se aqueles de caráter econômico, que partem do princípio que a água é recurso natural limitado e dotado de valor econômico. Portanto, seu uso e seu serviço ambiental devem fazer parte do sistema de mercado.

Todavia, inserir a problemática ambiental, em um contexto econômico baseado na economia de mercado, no qual o instrumento de regulação é o sistema de preços, tem sido desafio para os economistas - desde o final dos anos 60. O desafio está no fato de os ativos da natureza não terem um preço e um proprietário definidos; logo, o mercado não tem capacidade de solucionar os efeitos da escassez dos recursos.

\footnotetext{
* Efeitos econômicos colaterais de um processo de produção que não são considerados na formação do preço de mercado do seu produto. LANNA (1991)
} 
Neste contexto, o planejamento, o controle e a gestão dos recursos ambientais a partir de uma escala regional - tornam-se ações imprescindíveis na elaboração de políticas públicas. Assim, a intervenção do Estado parece ser necessária quando se trata de problemas relacionados ao meio ambiente. Urge, portanto, discutir e adotar instrumentos que regulem a alocação de recursos naturais e apóiem a implementação da sustentabilidade.

A respeito do emprego de instrumentos de gestão ambiental, ALMEIDA (1998) comenta que, no âmbito internacional, tem-se privilegiado o uso de instrumentos de regulação direta* ou comando e controle, devido à sua elevada eficácia ecológica - o que garante amplo apoio da sociedade e influencia a tomada de decisão dos políticos. Porém, apesar de ser tendência internacional a adoção de políticas de comando e controle, existem várias experiências na utilização dos instrumentos econômicos. No Brasil, o debate a respeito deles e principalmente seu emprego em gestão das águas são ações incipientes; entretanto, têm tomado corpo desde a aprovação da Política Nacional dos Recursos Hídricos (Lei Federal 9.433/97).

A Lei Federal 9.433/97 estabelece um conjunto de premissas que têm por objetivo assegurar a gestão integrada dos recursos hídricos. Dentre os instrumentos propostos pela Política Nacional de Recursos Hídricos, encontra-se a cobrança pelo uso da água. Disposta na lei como um dos instrumentos essenciais à boa gestão do uso da água, a cobrança tem por objetivos: racionalizar a utilização desse recurso natural, sob o preceito de sua escassez relativa; reconhecer a água como bem dotado de valor econômico, internalizando os custos sociais causados pelas externalidades derivadas de seu uso; e diminuir os conflitos entre usuários, alocando-os de maneira racional, com vistas ao gerenciamento da demanda.

A cobrança surge como instrumento econômico cuja aplicação - dentro de um sistema de gestão - pretende racionalizar a utilização do recurso natural e diminuir conflitos entre usuários. Assim, incentiva-os a atuarem conforme os objetivos da sociedade em relação à utilização do recurso ambiental. Para a eficácia da aplicação deste instrumento econômico é importante que ele exerça interação com os demais

\footnotetext{
* Emprego de instrumentos que impõem limites à atuação dos agentes, mediante estabelecimento de parâmetros, regras ou regulamentos, cuja obediência seria estimulada por penalização ou compensação, conjugados ao monitoramento e polícia ambiental. LANNA (1996)
} 
instrumentos preconizados na lei, servindo como complemento de políticas comando e controle e contando com a participação da sociedade - principalmente por meio dos comitês de bacia hidrográfica.

Outro aspecto importante a respeito da cobrança é a necessidade de reconhecêla como instrumento capaz de compor um sistema de gestão dos recursos hídricos cuja finalidade seja equilibrar oferta e demanda. Para isso, é necessário encarar a cobrança como mecanismo regulador de apropriação do recurso hídrico, e não como fonte de arrecadação para rateio de custos de investimento.

No Brasil, a aplicação da cobrança como instrumento de gestão tem por base legal uma política de gestão de recursos hídricos que estabelece a bacia hidrográfica como unidade administrativa. Dentro de uma bacia, compondo um sistema de gestão, existem reservatórios utilizados para distintas finalidades; reservatórios que possuem importância econômica, ecológica e social.

Em várias regiões, no tocante aos recursos hídricos, os reservatórios são fundamentais ao planejamento regional. Salto Grande é exemplo da importância de um reservatório no gerenciamento da água. Situado no município de Americana, SP, esse reservatório pertence ao contexto de aplicabilidade da cobrança, pois, em decorrência de uma elevada demanda, passa por processo de degradação ambiental acentuado e por conflitos potenciais de uso.

O reservatório de Salto Grande está em uma das regiões mais industrializadas do país, onde há elevada demanda de água tanto para indústria, como para agricultura e abastecimento urbano. Esse sistema apresenta níveis avançados de eutrofização e contaminação - resultantes, principalmente, do lançamento de efluentes industriais e esgoto sanitário.

A proposta do presente trabalho é fomentar a discussão sobre os instrumentos econômicos de gestão dos recursos hídricos e sua utilização em situações de escassez relativa, como no caso do reservatório de Salto Grande.

Para abordar este tema e atingir os objetivos propostos, este trabalho apresenta a seguinte estrutura: o primeiro capítulo apresenta o tema escolhido, seu contexto e a justificativa da escolha; o segundo capítulo relata os objetivos desta investigação; no terceiro capítulo são desenvolvidos alguns conceitos e aspectos gerais sobre gestão ambiental, das águas e seus instrumentos econômicos. 
O quarto capítulo é dedicado à apresentação e análise de algumas experiências internacionais em gestão das águas, com enfoque voltado às formas de emprego dos instrumentos econômicos nos respectivos sistemas gestores; no quinto capítulo são apresentadas e analisadas duas experiências brasileiras em gerenciamento de recursos hídricos, no que concerne, principalmente, à utilização dos instrumentos econômicos; o sexto capítulo descreve os materiais e métodos utilizados na realização do trabalho, enfocando a metodologia de cobrança empregada no estudo de caso.

O capítulo sétimo é reservado a um estudo de caso. Nele é realizado o exercício de aplicação da cobrança sobre alguns usos da água no reservatório de Salto Grande. Para isso, é feita a caracterização geral da área de estudo, a qual compreende a bacia do rio Atibaia e o próprio reservatório; depois são apresentados os dados necessários à aplicação da metodologia de cobrança - desenvolvida por SOUZA (1995) -, bem como a discussão dos resultados obtidos.

O oitavo capítulo é dedicado às conclusões da dissertação.

Finalmente, no nono capítulo são apresentadas as referências bibliográficas que deram suporte à realização deste trabalho. 


\section{Objetivos}

- Geral:

O objetivo precípuo do presente trabalho é avaliar a aplicação dos instrumentos econômicos na gestão dos recursos hídricos, em especial a cobrança sobre os usos da água, consideradas suas distintas possibilidades de implementação e metodologias aplicáveis.

- Específicos:

- Analisar o uso dos instrumentos econômicos de gestão das águas em algumas experiências internacionais: França, Alemanha, Inglaterra e País de Gales, Austrália, Chile, México; além de experiências brasileiras dos Estados do Ceará e São Paulo.

- Estudar a aplicação da cobrança sobre alguns usos da água no reservatório de Salto Grande em Americana, SP. 


\section{Gestão ambiental e gestão das águas}

A água é elemento integrante do patrimônio ambiental, portanto, sua gestão está inserida em um sistema maior - a gestão ambiental.

Segundo LANNA (2000), a gestão ambiental “é o processo de articulação das ações dos diferentes agentes sociais que interagem em um dado espaço, com vistas a garantir a adequação dos meios de exploração dos recursos ambientais - naturais, econômicos e sócio-culturais - às especificidades do meio ambiente, com base em princípios e diretrizes previamente acordados/definidos”. Ao final deste processo pretende-se, segundo o autor, "promover, de forma coordenada, o inventário, uso, controle, proteção e conservação do ambiente visando a atingir o objetivo estratégico do desenvolvimento sustentável”.

SOUZA (2000) comenta que a gestão ambiental pode ser entendida como um conjunto de procedimentos que têm por fim a conciliação entre desenvolvimento e qualidade ambiental. Esta conciliação acontece a partir da observância da capacidade de suporte do meio ambiente e das necessidades identificadas pela sociedade civil e pelos governos. Para o autor, a legislação, a política ambiental e a participação da sociedade são as ferramentas de ação da gestão ambiental.

Entre essas ferramentas destaca-se, aqui, a política ambiental e seus elementos. Como qualquer política, esta pode ser percebida como um processo por meio do qual interesses levam à formulação de decisões e ações continuadas, de modo a modificar situações dentro da sociedade. (SOUZA, 2000)

Neste contexto, e observando a qualidade de bem comum do meio ambiente, o Estado deve exercer papel dominante no trato das questões ambientais. Justifica-se a intervenção estatal devido a determinados conflitos oriundos da utilização de um bem comum; isto é, aquele que não pode ser oferecido a um sem ser ofertado a outro, mesmo que seja seu uso e não sua propriedade. 
Assim, a preocupação ambiental deve perpassar o espaço institucional de todas as políticas públicas. Porém, a política ambiental deve ser o referencial balizador de integração entre elas. De acordo com SOUZA (2000), para que uma política de meio ambiente seja consistentemente implementada, ela deve apresentar alguns elementos: os objetivos e pressupostos, os instrumentos e a definição dos aspectos institucionais.

LANNA (2000) enfatiza as vinculações existentes entre a gestão das águas e a ambiental. Segundo o autor, “a gestão das águas é a função deliberativa e executiva de compatibilidade das demandas de água (... ) aos planos e diretrizes globais de planejamento estabelecidos pelo Poder Público. No exercício desta função gerencial é realizado o planejamento, monitoramento, outorga (incluindo licenciamento e fiscalização) e administração das medidas indutoras do cumprimento das diretrizes estabelecidas pela negociação social efetivada neste modelo”.

Estabelecidas as diretrizes, princípios e objetivos da política das águas, para operacionalizá-la é preciso dispor de alguns instrumentos destinados ao alcance dos objetivos, os quais devem atender aos princípios da própria política. Entretanto, a implementação dos instrumentos pressupõe, entre outros aspectos, a definição do domínio sobre o recurso hídrico.

No Brasil as águas são de domínio da União ou dos Estados. São de domínio da União os lagos, rios e quaisquer correntes de água em terrenos de seu domínio, ou que banhem mais de um Estado, sirvam de limites com outros países; ou se estendam ao território estrangeiro ou dele provenham, assim como o mar territorial, os potenciais de energia hidráulica e os depósitos de água decorrentes de obras da União (CF/88, art. 20). São de domínio dos Estados as águas superficiais ou subterrâneas, emergentes e em depósito, ressalvadas, neste caso, na forma da lei, as decorrentes de obras da União, além dos lagos situados em terrenos do seu domínio e os rios que tenham nascente e foz no seu território (CF/88, art. 26).

Segundo MACHADO (2001), o domínio público da água, firmado na Política Nacional de Recursos Hídricos - Lei Federal 9.433/97 (art 1º I), não transforma o Poder Público Federal e Estadual em proprietário da água, mas torna-o gestor desse bem de uso coletivo. $\mathrm{O}$ autor relata as conseqüências da conceituação da água como bem de uso comum do povo: o uso da água não pode ser apropriado com exclusão de outros usuários potenciais; o uso da água não pode significar a poluição ou agressão 
a esse bem; o uso da água não pode esgotar o próprio bem utilizado; a concessão, a autorização ou qualquer tipo de outorga de uso da água deve ser fundamentada pelo gestor público.

Percebe-se que apesar de a política de gestão dos recursos hídricos observar os princípios gerais da política ambiental, ela é possuidora de peculiaridades devido às especificidades da água. Cita-se, como exemplo, o fato de ser um recurso ambiental desprovido de substituto para muitas de suas aplicações, entre as quais, o consumo humano e animal. Assim, a gestão das águas é dotada de caráter particular no que se refere aos objetivos, aos instrumentos e aos aspectos institucionais.

Como dito anteriormente, em virtude do caráter estratégico da água, e por ser ela um bem de domínio público, o Poder Público tem assumido a responsabilidade de gerenciá-la. Entretanto, verifica-se que as práticas de gestão adotadas pelos poderes públicos são as maiores causas da má alocação e poluição das águas. SERAGELDIN (1995) relata os principais problemas verificados em práticas de gerenciamento das águas pelo mundo:

- A fragmentação da gestão em diversos setores e instituições desarticuladas, que ignoram os conflitos e complementaridades entre os objetivos sociais, econômicos e ambientais;

- Desenvolvimento, operação e manutenção de sistemas de recursos hídricos, geralmente dependem sobremaneira da administração central. Raramente as comunidades ou o setor privado estão envolvidos nessas atividades, além de os usuários não participarem do planejamento e da gestão das águas;

- Muitos países não tratam a água como bem econômico, a ausência desta consideração pode levar ao desperdício e a elevados níveis de poluição;

- A relação entre qualidade das águas e a saúde, e entre meio ambiente e desenvolvimento econômico são negligenciadas. Este aspecto prejudica a qualidade de vida das populações presentes e futuras, além de perturbar a economia do país.

Baseado neste contexto, LOUCKS (2000) apresenta algumas diretrizes para o planejamento e a gestão sustentável dos sistemas de recursos hídricos: 
- Desenvolver uma visão compartilhada entre os anseios sociais, econômicos e ambientais, em benefício das presentes e futuras gerações, identificando maneiras de acordo com as quais todos os atores contribuam para o alcance desta visão;

- Desenvolver um arranjo institucional integrado e coordenado;

- Restaurar ou manter a atividade econômica, qualidade ambiental, saúde e biodiversidade dos ecossistemas naturais;

- Apoiar as ações que incorporem objetivos comuns e sustentabilidade econômica e sócio-cultural;

- Respeitar e assegurar os direitos de propriedade privada e trabalhar em coordenação com os agentes privados para execução dos objetivos comuns;

- Reconhecer que a economia, os ecossistemas e as instituições são sistemas complexos, dinâmicos e heterogêneos no espaço e no tempo. Portanto, a gestão deve levar em conta essas características;

- Integrar a melhor ciência disponível no processo de tomada de decisão;

- Monitorar e avaliar as ações para determinar se os objetivos estão sendo alcançados.

Neste sentido, GLEICK (2000) ressalta as mudanças que estão a ocorrer na gestão das águas, neste começo de século. $\mathrm{O}$ autor descreve estas mudanças como "a transformação do paradigma da água”, e observa que as políticas das águas, em todo mundo, já procuram enfatizar princípios de desenvolvimento que considerem valores ambientais, sociais e culturais. $\mathrm{O}$ autor destaca os princípios mais comuns desta nova abordagem da política das águas (e, conseqüentemente, na sua gestão):

- Atender as necessidades básicas do homem por serviços de água e esgoto;

- Atender a demanda dos ecossistemas por água;

- Usar alternativas não-estruturais para atender as demandas. (por exemplo: reúso de água, incentivos econômicos e institucionais);

- Aplicar, freqüentemente, princípios econômicos no uso e gestão das águas;

- Máxima eficiência e flexibilidade nos novos sistemas supridores de água;

- Envolver a sociedade nas decisões sobre gestão das águas. 
Percebe-se que as diretrizes, os princípios e objetivos das políticas de gestão de recursos naturais - em particular da água - são dotados de uma dinâmica que reflete as mudanças e os anseios do ser humano em diferentes gerações. Há 50 anos, por exemplo, as políticas eram voltadas para a ampliação do suprimento de água; hoje, o foco é o gerenciamento de sua demanda.

Esta mudança de direção é descrita por SERAGELDIN (1994) como a "Nova Agenda” de gestão das águas. A "Velha Agenda” abordava a necessidade de estender os serviços de saneamento básico como forma de proteção à saúde e ao bem estar social, porém não levava em consideração o estado das águas. Já a "Nova Agenda” reconhece a importância ecológica da água, e enfatiza que sua utilização deve seguir os preceitos da sustentabilidade com relação aos aspectos de quantidade e qualidade.

Pode-se afirmar que a década de 90 marca o início dessas transformações. Um novo paradigma para avaliar, desenvolver e gerenciar os recursos hídricos teve como origem principal as propostas da Conferência Internacional das Nações Unidas sobre Água e Meio Ambiente, ocorrida em janeiro de 1992 em Dublin na Irlanda; e as diretrizes estabelecidas na Conferência das Nações Unidas para o Meio Ambiente e Desenvolvimento, realizada no Rio de Janeiro em junho de 1992, na qual a água acabou por merecer todo o Capítulo 18 da Agenda 21.

Com a transformação do paradigma da água, pretende-se que os governos e a sociedade em geral incorporem os princípios necessários à sustentabilidade. Feito isto, o Poder Público possuidor da competência material sobre os recursos hídricos, poderá compatibilizar as metas de planejamento e os padrões almejados de qualidade ambiental e de eqüidade social.

No Brasil, a primeira iniciativa na abordagem do novo paradigma de gestão das águas foi dada em 1997, com a aprovação da Política Nacional de Recursos Hídricos e criação do Sistema Nacional de Gerenciamento de Recursos Hídricos (Lei Federal 9.433/97). Destaca-se, entre os fundamentos da política, aquele que reconhece a água como recurso natural limitado e dotado de valor econômico. Provém daí, a adoção dos princípios poluidor-pagador e usuário-pagador, por meio dos quais se preconiza a compensação financeira por dano e uso do recurso ambiental. Ressalte-se que, para operacionalização destes princípios, a Lei 9.433/97 instituiu a cobrança sobre usos da água - único instrumento de gestão de caráter econômico previsto na lei. 


\subsection{Instrumentos econômicos de gestão das águas}

\subsubsection{Contextualização dos instrumentos econômicos}

A preconização e a adoção dos Instrumentos Econômicos de gestão ambiental (IEs), nas respectivas políticas de meio ambiente, são ações consolidadas em países considerados economicamente desenvolvidos. Todavia, passam por um processo de discussão relevante nos países em desenvolvimento.

No Brasil é recente o debate a respeito dos IEs - especialmente a cobrança sobre usos da água. A necessidade atual de administrar a escassez das águas tem sido o motivo dessas discussões. Assim, a utilização dos IEs tem sido encarada como um modo de complementar as políticas de regulação direta ou comando e controle, no alcance do uso sustentável do meio ambiente.

Segundo CAIRNCROSS (1992), os instrumentos econômicos apresentam duas vantagens principais em relação aos instrumentos de regulação. A primeira é que, em curto prazo, podem garantir um certo nível de melhoria ambiental a um custo social menor do que o das regulações. Em segundo lugar, em longo prazo, os IEs oferecem, aos agentes econômicos e aos indivíduos, um motivo permanente para fazer mais do que exige as políticas de comando e controle.

A atuação dos IEs parte da noção que os recursos e serviços ambientais já não podem mais ser tratados desprovidos de valor econômico. Caso esta noção não seja trabalhada e discutida em uma sociedade, a tendência é que o sistema de mercado, devido à superexploração, leve os recursos naturais ao colapso. Assim, os preços dos recursos naturais deveriam refletir seus custos de oportunidade para que o mercado pudesse alocá-los eficientemente, sem a intervenção governamental. Todavia não é isso que acontece, até porque a alocação eficiente na ótica do mercado, quase sempre não considera os anseios da sociedade.

A incapacidade do mercado em alocar os recursos naturais de maneira racional, é justificada pelas falhas desse mesmo mercado. Elas ocorrem no momento em que o sistema de preços - instrumento de regulação dos mercados - falha na busca do ótimo social. Observa-se que a utilização dos recursos naturais gera custos e benefícios que não são captados pelo sistema de mercado. Desta forma, o custo ou benefício privado 
desses recursos, não considera seu custo ou benefício social; portanto, essa diferença indica a presença de uma externalidade.

A degradação e exaustão dos recursos naturais são exemplos de externalidades negativas. No caso da utilização dos recursos e serviços ambientais, a manifestação destas externalidades ocorre em virtude da indefinição dos direitos de propriedade de um bem público. Esta característica impede que esses bens sejam transacionados em mercados específicos, tornando impossível a transformação de seu valor em preços. (TISDELL, 1993; SEROA DA MOTTA et al., 1996)

As externalidades existem quando os agentes econômicos não arcam com todos os custos ou benefícios de decisões que afetam o bem-estar de terceiros. A ação dos instrumentos econômicos tenta transferir ao menos parte destes custos de volta para o indivíduo responsável pela decisão. Ressalta-se que um mecanismo semelhante deve existir para casos em que a decisão seja ambientalmente benéfica. Por exemplo: uma empresa que limpa a água poluída de que se abastece e despeja água limpa após usála em seus processos produtivos, de fato, criaria uma externalidade positiva; nestes casos, poder-se-ia discutir concessão de isenções e até de subsídios. (SEROA DA MOTTA et al., 1996)

Percebe-se que o uso dos recursos que a natureza oferece deve ser dotado de valor econômico. Além disso, deve fazer parte dos cálculos privados de custo e benefício de tal maneira que, as externalidades negativas causadas ao meio ambiente (custo social), sejam internalizadas; e que esse mecanismo (internalização em função do custo social de aproveitamento do recurso natural), seja capaz de evitar a poluição e o desperdício.

O problema está em fazer com que os agentes causadores de tais externalidades considerem-nas como custos. Para que isso ocorra, parece necessária a intervenção governamental - por meio dos incentivos econômicos, pois os agentes econômicos e o mercado não são capazes de caminhar no sentido da obtenção do ótimo social ou buscar soluções livremente negociadas. (ALMEIDA, 1998)

Artur Pigou, em 1920, já chamava atenção para a diferença que existe entre os custos marginais sociais e os privados. O autor defendia a existência de uma taxa que corrigisse essa distorção, ou seja, um meio de internalizar as deseconomias causadas pelos agentes econômicos, baseado na intervenção do Estado no sistema de mercado. 
Entretanto, nem sempre a intervenção governamental tem capacidade de solucionar uma falha de mercado. Esta, não corrigida ou corrigida parcialmente pelos Poderes Públicos, caracteriza falha do próprio mercado.

Assim, não há meios universalmente adotados para se atingir a melhor alocação dos recursos hídricos porque, tanto os mecanismos de mercado quanto os políticos e administrativos possuem deficiências. Portanto, a melhor alternativa é combinar os três mecanismos de maneira ponderada e em conformidade com as circunstâncias encontradas em cada sociedade. Como essas circunstâncias têm variação temporal, é indispensável o monitoramento da operação da alternativa escolhida, para garantir a retroalimentação do sistema adotado. (TISDELL, 1993)

Percebe-se que a adoção de IEs em qualquer política de gestão ambiental deve ser acompanhada de suporte institucional competente. Este aspecto tem sido um fator restritivo à implementação dos IEs nos países em desenvolvimento.

Acerca dessa realidade, SEROA DA MOTTA et al. (1998) comentam que boa parte da América Latina e Caribe tem legislações que estabelecem as instituições ambientais, e que criam oportunidades para utilização de instrumentos econômicos na gestão ambiental. Todavia, as fragilidades institucionais - como a insuficiência de recursos, inexperiência, jurisdição mal definida ou falta de vontade política - limitam a efetiva implementação dos IEs.

KEMPER (2001) enfatiza que a definição do direito de uso da água deve ser o ponto central de uma reforma institucional que tenha por objetivo a eficiência no uso e alocação das águas. No caso deste recurso natural, é preciso ficar clara a definição de quem são os usuários, onde se dá cada uso e a demanda individual; caso contrário, os próprios usuários não se sentirão estimulados a usar o recurso eficientemente, pois a eles não é dada a garantia que, se economizarem hoje, amanhã receberão mais.

Para aplicação dos IEs, esta definição é primordial e sua operacionalização pode ser feita por meio de um instrumento. No Brasil utiliza-se a outorga dos direitos de uso dos recursos hídricos.

Mesmo com possíveis restrições institucionais, tem sido encorajada a utilização dos IEs. Um exemplo disso é o princípio 16 da Declaração do Rio de Janeiro da Conferência das Nações Unidas para o Meio Ambiente e Desenvolvimento de 1992: “As autoridades nacionais devem se esforçar para promover a internalização dos 
custos de proteção do meio ambiente e o uso dos instrumentos econômicos, levandose em conta o conceito de que o poluidor deve, em princípio, assumir o custo da poluição, tendo em vista o interesse público, sem desvirtuar o comércio e os investimentos internacionais”.

É importante ressaltar que para o poluidor assumir o custo da poluição ele tem três alternativas: pagar pela poluição produzida (depende do método de valoração); abater toda a poluição gerada e assumir os custos totais de controle; e abater parte da poluição enquanto for mais barato que pagar pela poluição gerada - neste caso, parte da carga é abatida e parte é lançada.

Do ponto de vista do desenvolvimento sustentável, é interessante que o agente econômico opte pela segunda alternativa. Entretanto, para que isso ocorra, é preciso que o grau de incitação do instrumento econômico influencie na decisão do agente poluidor, com o objetivo de produzir melhoria na qualidade ambiental (seja ela por meio do controle da poluição ou racionalização do sistema produtivo).

É interessante destacar que caso o instrumento econômico aplicado não induza a mudança de comportamento por parte do usuário ou do poluidor, isto é, não altere as condições pelas quais os agentes econômicos tomam suas decisões, ele não pode ser considerado um instrumento econômico de gestão. Portanto, como o valor cobrado não retrata a escassez relativa do recurso natural e não induz ao equilíbrio entre a oferta e a demanda por aquele recurso, ocorre uma desvirtuação da ação do incentivo econômico.

Assim, a arrecadação - qual deveria ser conseqüência inerente à sua aplicação - torna-se a finalidade do instrumento. Neste contexto, o pagamento por uso ou dano ao meio ambiente torna-se uma obrigação de respeito às regras de uso do recurso natural, ou seja, o instrumento econômico transforma-se em uma "tabela de preços". Desta maneira, mesmo que ao usuário-poluidor seja dada a oportunidade de escolha (pagar e continuar poluindo ou diminuir o nível de poluição) - ele não se sente estimulado, porque pela utilização do recurso ou do serviço ambiental, normalmente ele paga um valor aquém do seu verdadeiro valor. Portanto, pode-se inferir que um instrumento conceituado como o econômico, na verdade presta-se a ser mais um instrumento de comando e controle. 


\subsubsection{Tipos de instrumentos econômicos}

A abordagem dos tipos de instrumentos econômicos aplicados no mundo segue a orientação dada pela Organização para Cooperação e Desenvolvimento Econômico (OCDE). Essa listagem não considera uma rígida concepção para os instrumentos econômicos. Portanto, não se trata de uma classificação, mas de simples enumeração. As incitações financeiras à conformidade como multas ou outro tipo de pagamento, feito pelo não cumprimento de regulação imposta, embora sejam consideradas pela OCDE como instrumentos econômicos, efetivamente parecem-se mais com instrumentos de comando e controle. Desta maneira, justifica-se sua ausência na listagem apresentada. (ALMEIDA, 1998)

\subsubsection{Taxas e Tarifas}

A aplicação das taxas e tarifas parte da constatação de que os custos ambientais não são voluntariamente apropriados pelos agentes econômicos. Assim, os preços dos produtos não incorporam o custo da utilização dos recursos naturais. A idéia da aplicação desse tipo de instrumento econômico é fazer com que a sociedade arbitre valor econômico ao recurso ambiental a ser utilizado, incluindo-o no sistema de produção - para garantir a internalização das externalidades e "equiparar” os custos privados aos custos sociais.

Foi concebida por Pigou, a base teórica para utilização das taxas, que passaram a ser conhecidas como "taxas pigouvianas". Originalmente elas foram propostas em sua obra Economics of welfare de 1920 e se tornaram, para muitos pesquisadores, o paradigma da eficaz intervenção dos governos naquelas situações em que ocorrem externalidades.

TISDELL (1993), porém, comenta que este mecanismo, quando aplicado à área ambiental, possui algumas falhas. A principal delas é o fato de sua aplicação poder ser ineficiente no abatimento da poluição, por atuar apenas no controle da quantidade produzida; poderia ser mais eficaz atuar diretamente na quantidade de poluição emitida. Outra limitação é que o modelo de Pigou assume ser perfeita a competição nos mercados. 
Segundo PEARCE \& TURNER (1990), não existe no mundo real uma condição teoricamente correta para a aplicação das “taxas pigouvianas”. Este aspecto é justificado pela dificuldade de se encontrar a função de dano, que expressa quanto o dano ambiental - medido em valores monetários - varia com o grau de poluição emitida. A obtenção desses valores é muito subjetiva; assim, os autores enfatizam que encontrar uma boa parte do custo marginal externo já é uma boa medida; ou seja, uma medida aceitável para o custo externo.

Na aplicação de incentivos que atuam na forma de preços - como é o caso das taxas e tarifas - a eficiência seria máxima quando os custos marginais - incorridos pelos agentes econômicos, em decorrência do uso de uma unidade de um bem ou serviço ambiental - fossem equivalentes ao custo ambiental (externo) imposto à sociedade por uso incremental. Porém, a definição das taxas segundo esse princípio, geralmente não é possível, pois necessita de esforço de coleta e análise de informações - nem sempre disponíveis a custos compensadores. (CAIRNCROSS, 1992; MENDES \& SEROA DA MOTTA, 1997)

Devido a essas dificuldades, ALMEIDA (1998) comenta que o uso das taxas vem se tornando mais flexível. Alcançar o nível de poluição ótimo e taxas ótimas não é mais a meta a ser atingida; busca-se sim um nível aceitável de poluição. (PEARCE \& TURNER, 1990)

Deste modo, como opção de política ambiental, usa-se um sistema misto taxapadrão. Neste caso, a taxa é o meio para atingir um padrão previamente estabelecido de qualidade ambiental. Desta maneira, a taxa deixa de ter seu valor determinado pelo dano marginal causado e pode assumir diferentes bases de cálculo. (ALMEIDA, 1998)

Percebe-se que a busca por níveis ótimos de poluição - abordagem da Análise Custo Benefício (ACB) - retira-se de cena. Pretende-se, apenas, encontrar um nível que minimize o custo total para se atingir um determinado objetivo de qualidade abordagem da Análise Custo Efetividade (ACE). A aplicação do princípio poluidorpagador por meio da ACB, pretende que os poluidores internalizem as externalidades geradas até atingir o ponto ótimo de poluição. Já a ACE, pretende que os poluidores internalizem os custos de controle até o ponto desejável para o alcance do padrão de qualidade estabelecido. (CÁNEPA et al.,1999) 
No caso da cobrança sobre os usos da água, uma alternativa é a aplicação de taxas ou tarifas proporcionais à quantidade de água consumida ou poluição emitida, consideradas as distintas características ambientais, a saturação do corpo de água (em conformidade com o padrão de qualidade), a sazonalidade e as diferentes atividades instaladas na região em estudo. Para o cálculo do valor unitário de cobrança (por m³), várias metodologias podem ser empregadas.

Neste contexto, CARRERA-FERNANDEZ* apud GARRIDO (2000) enquadra as metodologias de formação de preços em três grupos: modelos de otimização com equilíbrio parcial; modelos de otimização com equilíbrio geral; e modelos "ad hoc". As metodologias dos dois primeiros grupos são aquelas dotadas de subjetividade ou dificuldade de mensuração, por dependerem da conduta de otimização do agente econômico como ponto de partida para a formação dos preços. No terceiro grupo, estão aquelas que não apresentam processo legítimo de otimização econômica.

Fazem parte do primeiro grupo os preços baseados na disposição a pagar e no custo marginal de curto e longo prazo. No segundo grupo estão o preço de mercado (certificados negociáveis) e o preço ótimo. Por fim, no terceiro grupo encontra-se o preço pelo custo médio e o preço “ad hoc”. É importante destacar que a metodologia de cobrança utilizada no estudo de caso deste trabalho está baseada no custo médio de sistemas de tratamento de efluentes líquidos, ou seja, fundamenta-se no custo de controle da poluição, portanto, segue os modelos “ad hoc".

Principais vantagens da utilização das taxas: possibilitar que as empresas escolham o nível de tratamento dos seus efluentes; propiciar fundo financeiro para o controle da poluição; permitir o atendimento do princípio poluidor-pagador; induzir à adoção de tecnologias limpas e à racionalização do uso dos recursos naturais; obrigar o agente poluidor a considerar, em seu custo de produção, o dano ambiental causado.

* CARRERA-FERNANDEZ, J. (2000). Estudo de cobrança pelo uso da água em bacias hidrográficas: teorias, metodologias e uma análise dos estudos no Brasil. Salvador. 


\subsubsection{Subsídios}

Subsídios são benefícios financeiros oferecidos aos agentes poluidores, cujo objetivo é incentivá-los a reduzir os níveis de degradação ambiental. No caso dos recursos hídricos, subsídios podem ser concedidos para que os poluidores diminuam os lançamentos de efluentes, por meio da modificação dos processos produtivos ou tratamento de efluentes. Podem também ser ofertados aos usuários que captam, para que moderem o consumo.

De acordo com a OCDE os subsídios podem ser divididos em três modalidades:

- Subvenções: formas de ajuda financeira não reembolsáveis;

- Empréstimos subsidiados: financiamentos concedidos com taxas de juros menores que as de mercado;

- Incentivos fiscais: depreciação acelerada e outras maneiras de isenção ou redução de impostos.

MARTINEZ JR. (1997) relata que a utilização de subsídios leva à iniqüidade e a situações economicamente ineficazes. Segundo o autor foram essas características que incitaram a OCDE a condenar a aplicação desse tipo de instrumento econômico, já que os considerava incompatível com os princípios: poluidor-pagador e usuáriopagador. Mesmo assim, alguns países constituintes da OCDE ainda utilizam esse tipo de instrumento para controle ambiental da água.

ALMEIDA (1998) afirma que a justificativa para a concessão de subsídios não está na gravidade do problema ambiental, mas nas alegadas dificuldades financeiras dos poluidores em satisfazer as exigências impostas pelos reguladores. Assim, a assistência financeira passa a ser componente necessária à regulação direta. De maneira geral, os subsídios ainda são utilizados nas políticas de gestão ambiental pois, entre outros fatores, aceleram a reestruturação de antigas fábricas e incentivam a introdução de tecnologias não poluentes.

MENDES \& SEROA DA MOTTA (1997) frisam que esse tipo de instrumento econômico é adequado em casos específicos de setores com impacto econômico significativo e que tenham necessidade de ajustes emergenciais. 


\subsubsection{Sistemas de devolução de depósitos}

Também conhecido como sistemas de consignação; trata-se de uma sobretaxa aplicada ao preço dos produtos com potencial poluidor. Na medida que a poluição é evitada pelo retorno dos produtos - embalagens ou seus resíduos - via algum sistema de coleta e tratamento, aquela sobretaxa é reembolsada. Esses sistemas podem ser espontaneamente adotados pelos setores industriais, acordados entre o poder público e as indústrias, ou impostos pelos governos.

Para controle da poluição das águas, esse tipo de instrumento econômico incide sobre recipientes que contenham produtos tóxicos como praguicidas e metais pesados (pilhas e baterias).

ALMEIDA (1998) comenta que os sistemas de devolução de depósitos são considerados eficientes do ponto de vista administrativo, pois não necessitam de monitoramento ou qualquer envolvimento governamental; porém, é necessário estar atento a questões relativas à fiscalização. O autor op cit. comenta ainda, que sistemas de consignação são compatíveis com o princípio poluidor-pagador, uma vez que os consumidores pagam por uma poluição potencial que podem vir a causar.

\subsubsection{Mercado de direitos de poluição}

Os Mercados de Direitos de Poluição inicialmente foram propostos - por Dele, em 1968 - como instrumento. Consiste basicamente em, artificialmente, criar um “mercado para poluição”, o qual permite que os direitos ou cotas de poluição sejam transacionados entre os agentes econômicos proprietários desses direitos. Trata-se, portanto, de licenças negociáveis de poluição.

Segundo LANNA (1999), os mercados operam em dois níveis. Primeiramente, o poder público - responsável pelo licenciamento de atividades poluidoras - avalia a capacidade de suporte de dado corpo natural (camada de ar sobre uma região, lago, curso de água etc.), baseado na capacidade de assimilação ou em aceitáveis níveis de poluição. Posteriormente, são emitidos títulos que permitem o lançamento de carga poluidora. A soma das cargas poluidoras que constam em cada título deve ser igual à estabelecida como suportável pelo corpo natural. 
No segundo nível, os agentes detentores das “permissões de poluir” devem compatibilizar suas emissões de acordo com a quantidade de títulos disponíveis, seja pelo controle da poluição seja pela aquisição de mais títulos. Com a livre negociação de títulos ou cotas, cria-se o mercado de "direitos de poluir" que atua via quantidade e não via preço da poluição.

Aspecto importante para regulamentação das licenças de poluição é a maneira como são distribuídas. Isso pode ser gratuito, de acordo com o nível de emissão previamente licenciado, ou em forma de leilão, que tem a vantagem de gerar receita. LANNA (1999) ressalta que cabe ao poder público decidir a forma de distribuição das licenças e monitorar os detentores dos títulos, para verificar se os lançamentos estão em conformidade com as licenças que atribuem tais direitos.

SEROA DA MOTTA (1998) afirma que para um mercado alocar, de maneira eficiente, os direitos de poluição, é necessário atentar para alguns condicionantes de propriedade e competitividade. Isto é, requer direitos de propriedade bem definidos, um grande número de negociadores - com diferentes custos e benefícios, e fraca interdependência de mercado.

\subsubsection{Mercado de direitos de uso}

Como antes mencionado, a dificuldade de estabelecer direitos completos de propriedade dos recursos ambientais torna sua alocação ineficiente pela incapacidade dos sistemas de mercado na atribuição dos preços dos recursos. Caso esses direitos fossem bem definidos, poderia ocorrer negociações entre usuários (de maneira que os usos de maior retorno (mais eficiente) fossem priorizados). Ou seja, as trocas de direitos no mercado induziriam os usuários de maior benefício de uso (ou menor custo) a pagarem mais por estes direitos. Dessa maneira, poderia haver melhoria na eficiência de utilização do recurso, por meio da introdução do custo de oportunidade. (EASTER \& HEARNE, 1995; SEROA DA MOTTA, 1998)

No mercado de direitos de uso, a titularidade do recurso natural água continua pública, porém permite que o direito de uso por quantidade - fornecido por meio da outorga - seja negociado pelos usuários. Esse instrumento é equivalente ao anterior, 
mas, para alocação quantitativa do recurso natural, não incluindo o uso para diluição de efluentes. (LANNA, 1999)

No mercado de direito de uso, o usuário se dispõe a pagar o valor adicional que o uso daquele recurso gera na sua produção. Neste caso, o próprio mercado se incube de definir os valores de transação do recurso natural, portanto, não é preciso valorar seu uso; a imprecisão no processo de alocação é limitada ao dimensionamento da capacidade suporte do meio natural. (SEROA DA MOTTA, 1998)

BAUER (1997) frisa, todavia, que os recursos hídricos são interconectados e que a transação dos direitos de uso pode afetar outros usuários e o meio ambiente. Devido a estes aspectos e às incertezas e sazonalidade inerentes do ciclo hidrológico, a obtenção de informações tem elevado custo e baixo grau de confiabilidade; e os direitos de uso não são claramente definidos. Portanto, estabelecer um mercado de direitos de uso não é simples, por envolver diversos interesses e elevados custos de transação.

Neste contexto, LANNA (1999) relata alguns fatores para que um mercado de direitos de uso exista e promova a eficiência econômica, social e ambiental de uso do recurso natural: todas as partes atingidas pelos resultados devem estar envolvidas nas negociações de mercado; agentes envolvidos nas negociações devem ser informados a respeito das conseqüências de suas decisões; que a distribuição de renda existente seja adequada, para que disparidades não interfiram na disposição a pagar dos participantes do mercado. 


\section{Algumas experiências internacionais em gestão das águas e os instrumentos econômicos}

Neste capítulo são apresentadas e analisadas algumas experiências estrangeiras em gestão das águas. Foram escolhidos países que possuem maior tradição na prática de gestão, principalmente no emprego dos instrumentos econômicos, como França, Alemanha, Chile, Inglaterra e País de Gales. As demais experiências escolhidas para estudo foram as da Austrália e do México, por possuírem peculiaridades importantes na aplicação dos IEs.

Busca-se abordar essas experiências frente aos respectivos contextos histórico e institucional, embora, o objetivo principal da análise esteja voltado às formas e sistemas de utilização dos instrumentos econômicos. Para tanto, são apresentados os métodos de cálculo para definição dos valores (no caso de cobrança sobre usos da água) e o funcionamento dos mercados de direito de uso das águas. Em cada caso, procura-se identificar características, variáveis, finalidades e resultados da aplicação dos instrumentos econômicos, além de suas interfaces com instrumentos de comando e controle que compõem os respectivos sistemas de gestão. Ao final do capítulo são feitas algumas considerações sobre as experiências abordadas.

\subsection{Caso da França}

Na França, a política das águas é responsabilidade do Ministério do Ambiente, que possui papel de coordenação central das demais instituições encarregadas da gestão das águas. No sistema político francês são distintas as tarefas dos Poderes Legislativo e Executivo; cabe ao primeiro a aprovação das leis, e ao segundo aplicálas e regulamentá-las mediante decretos. Relativa à política das águas, a promulgação da Lei da Água em 1964 transformou-se no marco legal de reestruturação do sistema francês de gerenciamento dos recursos hídricos, que foi incentivada pela eminente 
degradação das águas - resultante da crescente industrialização e urbanização. A operação do novo sistema teve início em 1968.

A Lei da Água reconheceu a necessidade de lutar contra o avanço da escassez. Com esse intuito, deu-se prioridade à implantação da gestão das águas que visasse a melhoria da qualidade dos ambientes aquáticos e viabilizasse a obtenção de recursos financeiros para investimentos essenciais ao alcance dos objetivos. Entre os aspectos considerados pela lei, destacam-se: a atribuição ao Estado do poder de polícia para o controle da qualidade das águas; a fixação de objetivos de qualidade da água e prazos para que fossem alcançados; a instituição da bacia hidrográfica como unidade administrativa de gestão das águas; a criação dos Comitês de Bacia e das Agências Financeiras de Bacia Hidrográfica (Agências de Água); a criação do fundo especial de investimentos.

BARRAQUÉ (1995) observa que dentre os aspectos da lei de 1964, a fixação de objetivos de qualidade da água era o procedimento mais complicado e teve sua aplicação restrita a somente um corpo de água. A ausência dessa planificação deveuse, entre outros fatores, ao relativo desinteresse dos departamentos regionais na dimensão ambiental das políticas públicas, e à falta de informações concernentes aos impactos da poluição sobre os diversos meios aquáticos. Assim, na época, optou-se pela utilização de mapas de qualidade dos rios e, logo depois, por contratos de rio procedimento informal, entre os habitantes ribeirinhos - para partilha dos custos de limpeza e manutenção das margens e leito dos rios.

O Estado francês, ao reconhecer o aumento da escassez dos recursos hídricos, iniciou a reformulação do sistema de gestão das águas, ao qual foram acrescentados dois níveis regionais de administração: a Região e a Bacia Hidrográfica. Além disso, o Estado passou a impor restrições de uso até para aqueles que tinham domínio sobre as águas. Desta maneira, passou-se progressivamente do direito da água estruturado por uma oposição entre a apropriação pública e a privada, para outro baseado no princípio de uso. Atualmente, encontra-se consolidada a definição da tutela sobre os recursos hídricos da França. (BARRAQUE, 1995)

As águas consideradas “fechadas” (lagos artificiais), as águas subterrâneas e as águas das nascentes captadas em solos privados são consideradas propriedade dos donos da terra. As águas correntes (navegáveis e flutuáveis) são públicas (dominiais), 
bem como seu leito. Águas correntes não dominiais são bens que, no sentido jurídico, não podem ser apropriados, porém, seu uso é objeto de divisão. Assim, pode-se dizer que, na França, a água é gerida segundo o princípio do uso eficazmente partilhado; para tanto, esse uso é submetido a um sistema de autorizações. (BARRAQUÉ, 1995)

Um dos principais aspectos da Lei da Água foi a criação das Agências de Bacia que viriam a ser o marco institucional da gestão dos recursos hídricos franceses. As seis bacias hidrográficas francesas possuem suas respectivas Agências, cada qual dirigida por um Conselho de Administração composto por: oito representantes das coletividades territoriais, oito representantes dos usuários, oito representantes do Estado e um representante do corpo técnico da Agência. De alguma forma, a Agência constitui o executivo do Comitê de Bacia, e tem como funções: aplicar o plano de investimentos; aplicar e arrecadar o produto da cobrança sobre usos da água; efetuar estudos para ter noção da disponibilidade quantitativa de água e da sua qualidade; preparar novas metas de ação para os próximos planos.

Aos Comitês de Bacia, por sua vez, cabe deliberar sobre as ações necessárias à boa gestão das águas na respectiva bacia. Inicialmente, sua constituição era tripartida entre representantes dos usuários, das coletividades locais e do Estado. Após o afastamento do Estado do financiamento da política das águas, sua representatividade caiu a 25\%, em proveito dos usuários e ambientalistas. Normalmente, cada Comitê é consultado sobre o programa de intervenção na bacia, programa esse elaborado pela Agência referente à aplicação dos recursos financeiros necessários à execução dos programas e sobre a fixação das taxas do sistema de cobrança sobre usos da água.

Percebe-se que os Comitês são instituições de caráter consultivo/deliberativo e que as Agências são órgãos executivos. BARRAQUÉ (1995) comenta que a criação das Agências era necessária devido aos seguintes fatores: a regulamentação da luta contra a poluição era insuficiente e mal aplicada; o Estado possuía vocação de apoio ao desenvolvimento econômico e relegava o meio ambiente a segundo plano. Assim, como os serviços de água eram considerados bens de caráter industrial e comercial, foi mais fácil aplicar uma forma do princípio poluidor pagador, que ficou a cargo das Agências de Bacia.

As Agências são organismos de resolução de conflitos entre usuários das águas e de financiamento. Seu funcionamento é garantido pela cobrança sobre usos da 
água, considerada como tributo. No entanto, a cobrança é o único tributo importante que não é gerido pelo Ministério das Finanças, o que evita que seja apenas fonte de recursos financeiros para os cofres públicos do Estado francês.

Ressalta-se que, como novo tributo, a cobrança encontrou resistência para sua implantação, tanto dos usuários quanto do sistema político. Uma estratégia utilizada a fim de quebrar essa resistência foi o estabelecimento da cobrança de forma gradual. Mesmo assim, a cobrança sobre captação ainda não foi implantada em algumas subbacias, e parte dos irrigantes não participa do sistema. (SEROA DA MOTTA, 1998)

Este sistema estabelece a cobrança sobre captação e lançamento de efluentes, com seus valores calculados separadamente, porém, cobrados juntos. Também estão sujeitos à cobrança aqueles que modificam o regime das águas e se beneficiam dos serviços ou obras executados com participação financeira da Agência. O valor para a captação divide-se em uma pequena parte para a retirada propriamente dita e uma grande parte para a água consumida. Ele é estipulado em função de metas ambientais e necessidades de investimentos. Assim, são diferenciados para cada bacia e muitas vezes não retratam o real valor do recurso, parece mais um rateio de despesas futuras para recuperação do meio. (BARRAQUÉ, 1995; SEROA DA MOTTA, 1998)

Segundo SEROA DA MOTTA (1998), os investimentos com a receita gerada são feitos na forma de despesas com gestão, estudos e pesquisas, investimentos de interesse comum e empréstimos aos usuários. Com a receita, os Comitês conseguem cobrir $40 \%$ dos investimentos na bacia, os outros $60 \%$ são cobertos por recursos do governo central. Afirma-se que os investimentos são definidos qüinqüenalmente.

Percebe-se que o principal enfoque da cobrança está na capacidade da geração de receita para investimentos na bacia onde foram geradas. Portanto, neste contexto, a aplicação do instrumento visa a viabilidade financeira. A cobrança geralmente é aplicada para qualquer tipo e volume de efluente, até mesmo aqueles dentro dos padrões legais de emissão. A ênfase na recuperação de custos, relacionando-os pouco às considerações ambientais específicas, pode até ser um primeiro passo, mas não o suficiente para dar incentivos à promoção do uso eficiente da água.

Sobre essa eficiência, BARRAQUÉ (1999a) reconhece que os baixos valores cobrados não induziram os usuários de água ao uso racional do recurso preconizado pelo princípio poluidor pagador. O autor afirma que é o princípio da solidariedade ou 
mutualidade que norteia a cobrança sobre usos da água na França, pois se trata de um rateio proporcional dos custos de investimento para a bacia. Neste rateio, o valor cobrado pára no ponto em que o sistema produz dinheiro suficiente para ajudar os usuários a reduzir seus impactos, de maneira que se atinge um nível médio de qualidade da água que satisfaz à maioria dos usos dos recursos (o que não significa a restauração de um estado próximo ao original).

O op cit. afirma, ainda, que foi alcançada melhoria na qualidade da água por meio de investimentos em tecnologia, e não devido ao decréscimo do consumo ou do lançamento de efluentes. O sistema de gestão da água, de início, foi constituído para lutar contra a poluição causada pelas descargas pontuais. Este objetivo foi alcançado com êxito, entre outros fatores, em virtude da regulamentação relativa aos rejeitos poluentes, ao auxílio financeiro e assistência técnica que se pode obter das Agências. Porém, ocorreu uma diminuição de águas de muito boa qualidade.

Agora a atenção está voltada para a redução da poluição difusa, incluindo-se aí as descargas urbanas nas enxurradas, a diminuição de substâncias tóxicas e dos nutrientes (fosfatos e nitratos) que provêm da agricultura e estações de tratamento de efluentes. A atenção está direcionada, ainda, para operar e manter os equipamentos existentes, e atingir certo nível de desenvolvimento sustentável por meio de gestão mais integrada.

Percebe-se que o sistema francês de cobrança aponta para um mecanismo de obtenção de recursos que, mesmo retornando para a bacia em forma de subsídio, não incita o usuário à mudança de comportamento na utilização do recurso natural. Ainda assim, percebe-se que houve melhoria inegável dos recursos hídricos daquele país ou, pelo menos, manteve-se a qualidade de há 20 anos.

O dinheiro advindo da cobrança segue um plano de investimentos de melhoria da qualidade ambiental de cada bacia. Os resultados colhidos dessa política mostram que houve melhoria na qualidade dos recursos hídricos da França, mas a adoção de novos instrumentos e o monitoramento da situação do meio faz-se necessário até como retroalimentação do sistema adotado.

A procura por uma gestão mais integrada tem sido feita - com mais êxito - a partir da lei de 1992, na qual a meta ambiental para os recursos hídricos ficou mais clara, colocando-se o conjunto da água e dos meios aquáticos no "patrimônio comum 
da nação”, e propondo aos usuários agruparem-se em “comunidades locais da água”. A proposta da lei é equilibrar a atuação das Agências de Água - exercida por meio de incentivo econômico - com a atuação de instrumentos de regulação direta. Neste contexto, os pontos mais importantes considerados pela nova lei são: modificação do direito das águas; unificação da polícia das águas; generalização do regime de autorizações de captação e descarga em águas superficiais e subterrâneas; retomada do projeto de planificação da gestão dos recursos hídricos. (BARRAQUÉ, 1999a)

Para pôr em prática os novos instrumentos propostos, houve distribuição de tarefas entre diferentes esferas administrativas. No âmbito central - coordenando 22 Direções Regionais do Ambiente (DIREN) - está a Direção da Água vinculada ao Ministério do Ambiente. As DIREN são responsáveis pelo sistema de licenças para captação e lançamento de cargas poluentes. Cabe ao Ministério da Saúde Pública o estabelecimento dos padrões de qualidade da água. Já a polícia das águas é efetuada pelo Estado por meio dos serviços departamentais.

Dentre os pontos contemplados pela lei de 1992, destaca-se o retorno ao debate sobre a planificação da administração dos recursos hídricos. Com esse objetivo, dois instrumentos de gestão foram propostos: Esquemas Diretores de Aproveitamento e de Gestão das Águas (SDAGE) e Esquemas de Aproveitamento e de Gestão das Águas (SAGE). O primeiro é confeccionado por cada Comitê de Bacia e observa os planos e programas propostos para ela. Já os SAGE são mais específicos, pois estão restritos às sub-bacias ou seus grupos; sua formulação é feita pelas Comissões Locais da Água, vinculadas às Comunidades Locais da Água e formadas por 50\% de representantes das coletividades locais, 25\% de representantes do Estado e 25\% de representantes dos usuários. (BARRAQUÉ, 1999a)

Percebe-se que, para fomento de gestão integrada, a França adotou novos instrumentos e descentralizou alguns procedimentos, inclusive revitalizando os níveis administrativos locais. Entretanto, outro fator concorre para que sejam alcançados os objetivos da lei de 1992: a organização de um sistema de informações que tem subsidiado as ações propostas em planos e programas. O Ministério do Ambiente e as Agências de Água estão ligados a uma Rede Nacional de Dados sobre as Águas (RNDE), o qual recebe, de cada bacia, informações referentes à saúde do ambientes aquáticos, disponibilidade hídrica, pluviometria, usos múltiplos da água etc. 
Apesar dessa evolução da política das águas na França, ela ainda necessita do desenvolvimento da sua integração à gestão de uso do solo. Essa carência se deve à histórica confrontação entre o Estado e a propriedade privada. (BARRAQUÉ, 1999b)

\subsubsection{Formação do valor cobrado na França}

A determinação do valor da cobrança é responsabilidade dos Comitês/Agências de Bacia, e feita de acordo com estrutura fixada por lei, dada pela equação (1):

$$
\text { Cobrança }=\text { Q . U . S . A }
$$

Onde:

Cobrança $=$ Valor anual a ser pago pelo usuário (\$)

$\mathrm{Q}=$ Quantidade de água consumida ou poluição gerada $\left(\mathrm{m}^{3} \mathrm{ou} \mathrm{kg}\right)$

$\mathrm{U}=$ Valor unitário da cobrança $\left(\$ / \mathrm{m}^{3}\right.$ ou $\left.\$ / \mathrm{kg}\right)$

$\mathrm{S}=$ Coeficiente setorial

$\mathrm{A}=$ Coeficiente ambiental

A cobrança é baseada em um valor unitário, modificado por dois coeficientes multiplicadores, e proporcional à quantidade de água consumida ou poluição gerada. Cabe destacar que, para o lançamento de efluentes, a quantidade de poluição gerada “Q” é um valor diário médio referente ao mês de maior produção de resíduos. Caso o poluidor adote um sistema de tratamento de efluentes, a ele é dada uma bonificação calculada em função da quantidade diária média de poluição evitada.

Para a captação de água, a escassez aparece contemplada pelo valor unitário variável "U” - que, de acordo com SEROA DA MOTTA (1998), varia para águas superficiais e subterrâneas, e por zonas de escassez dentro de cada bacia. Esta diferenciação por zonas também considera a necessidade de investimentos. Para água subterrânea o valor unitário varia entre US\$ $0,014 / \mathrm{m}^{3}$ e US\$ $0,044 / \mathrm{m}^{3}$, enquanto que para água superficial, como a cobrança ocorre apenas em zonas de alta escassez nas épocas de racionamento, pode chegar a mais de US\$ 0,050/ $\mathrm{m}^{3}$. Para a irrigação, em 1998, esses valores eram de US\$ $0,005 / \mathrm{m}^{3}$ para águas superficiais e US\$ 0,012 para as subterrâneas, na bacia Adour-Garonne ao sudoeste da França. (NAGARAJ, 1999) 
Para o lançamento de efluentes, a variável "U” é diferenciada por poluente e uniforme para toda a bacia - de acordo com a especificidade desta, com os objetivos da política e os planos de investimento. Para o cálculo da cobrança de um mesmo usuário que possui distintos poluentes considerados na análise da qualidade da água, os parâmetros são agregados de forma aditiva. São empregados: materiais suspensos; materiais oxidáveis; sais solúveis; substâncias inibidoras; nitrogênio reduzido; fósforo; compostos orgânicos alógenos; metais e não-metais. Os materiais oxidáveis (MO) são determinados por uma média ponderada da demanda química de oxigênio (DQO) e da demanda bioquímica de oxigênio $\left(\mathrm{DBO}_{5,20}\right)$, dada pela equação (2).

$$
\mathrm{MO}=\left[\mathrm{DQO}+2\left(\mathrm{DBO}_{5,20}\right)\right] / 3
$$

O coeficiente setorial "S” é usado para diferenciar o usuário. Segundo SEROA DA MOTTA (1998), o coeficiente de consumo urbano por quantidade, normalmente é superior ao industrial.

No que concerne ao cálculo da cobrança sobre efluentes urbanos, o coeficiente setorial "S" contempla: um coeficiente de zona (CZ) (TABELA 1), que é fixado em conformidade com as prioridades e objetivos de qualidade definidos pelos Comitês de Bacia; um coeficiente de aglomeração (K) (TABELA 2), que varia em função da população permanente e sazonal; e um coeficiente de coleta (CC) (TABELA 3), que considera os custos de financiamento de redes de esgoto. Para este caso, a cobrança anual é determinada pela equação (3):

$$
\text { Cobrança }(\mathrm{LU})=\mathrm{N}^{\circ} \mathrm{EH} . \mathrm{EH} \cdot \mathrm{CC} \cdot \mathrm{CZ}
$$

Onde:

Cobrança $(\mathrm{LU})=$ Valor cobrado sobre lançamanto de efluentes urbanos (\$) $\mathrm{N}^{\circ} \mathrm{EH}=$ (população permanente $+0,4$. população sazonal) $\cdot \mathrm{K}$

$\mathrm{EH}=$ Equivalente habitante $(\$)$

CC $=$ Coeficiente de coleta

$\mathrm{CZ}=$ Coeficiente de zona

O equivalente habitante é retratado pela quantidade diária de poluição gerada por habitante, multiplicada pelos valores unitários de cada poluente. De acordo com a Portaria de 10 de dezembro de 1991, cada habitante produz por dia: 90 gramas de 
materiais suspensos (MS); 57 gramas de materiais oxidáveis (MO); 0,2 équitox de substâncias inibidoras (SI); 15 gramas de nitrogênio reduzido (NR); 4 gramas de fósforo total (P); 0,05 gramas de compostos orgânicos alógenos (AOX); 0,23 gramas de metais e não-metais (METOX). (MARTINEZ JR., 1997)

TABELA 1 - Coeficientes de zona (CZ) para cada bacia (1994).

\begin{tabular}{c|c|c|c|c|c}
\hline $\begin{array}{c}\text { Adour- } \\
\text { Garonne }\end{array}$ & $\begin{array}{c}\text { Artois- } \\
\text { Picardie }\end{array}$ & $\begin{array}{c}\text { Loire- } \\
\text { Bretagne }\end{array}$ & Rhin-Meuse & $\begin{array}{c}\text { Rhône- } \\
\text { Mediterranée }\end{array}$ & $\begin{array}{c}\text { Seine- } \\
\text { Normandie }\end{array}$ \\
\hline 1,0 & 1,0 ou 1,3 & 1,0 ou 1,15 & 1,0 a 5,0 & 0 a 1,3 & $\begin{array}{c}1,0 \text { ou } \\
1,15 \text { ou } \\
1,25\end{array}$ \\
\hline
\end{tabular}

Fonte: NICOLAZO (1994)* apud MARTINEZ JR (1997).

TABELA 2 - Coeficientes de aglomeração (K) de acordo com a população.

\begin{tabular}{c|c|c}
\hline Classes & População & Coeficientes de aglomeração \\
\hline Classe 1 & Até 500 habitantes & 0,50 \\
Classe 2 & De 501 a 2.000 habitantes & 0,75 \\
Classe 3 & De 2.001 a 10.000 habitantes & 1,00 \\
Classe 4 & De 10.001 a 50.000 habitantes & 1,10 \\
Classe 5 & Superior a 50.000 habitantes & 1,20 \\
Classe 6 & Aglomeração de Paris & 1,40 \\
\hline
\end{tabular}

Fonte: MARTINEZ JR. (1997).

TABELA 3 - Coeficientes de coleta (CC) para cada bacia (1994).

\begin{tabular}{c|c|c|c|c|c}
\hline $\begin{array}{c}\text { Adour- } \\
\text { Garonne }\end{array}$ & $\begin{array}{c}\text { Artois- } \\
\text { Picardie }\end{array}$ & $\begin{array}{c}\text { Loire- } \\
\text { Bretagne }\end{array}$ & Rhin-Meuse & $\begin{array}{c}\text { Rhône- } \\
\text { Mediterranée }\end{array}$ & $\begin{array}{c}\text { Seine- } \\
\text { Normandie }\end{array}$ \\
\hline 2,0 & 1,85 & 1,5 ou 2,0 & 2,70 & 2,0 ou 2,5 & 2,6 \\
\hline
\end{tabular}

Fonte: NICOLAZO (1994)* apud MARTINEZ JR (1997).

Percebe-se que dentre os coeficientes usados para cobrança sobre lançamento de efluentes de áreas urbanizadas, apenas o coeficiente de aglomeração (K) possui valores abaixo de 1 (um) (TABELA 2). Assim, é interessante observar que este coeficiente, no caso das pequenas áreas urbanas, funciona como "subsídio social”.

\footnotetext{
* NICOLAZO, J. L. (1994). Les agences de l'eau. Paris, Pierre Johanet et ses Fild Éditeurs.
} 
Ainda relativo aos tipos de usuários, MARTINEZ JR. (1997) observa que as Agências das Bacias Adour-Garonne e Loire-Bretagne (oeste da França) cobram dos usuários de água que a utilizam para a geração de energia elétrica, por modificar o regime das águas. O valor é calculado com base no volume anual de água turbinado e no desnível introduzido pelas barragens. Na região de jurisdição da Agência AdourGarone o volume é calculado de acordo com a equação (4):

$$
\mathrm{V}=450 . \mathrm{W} / \mathrm{H}
$$

Onde:

$\mathrm{V}=$ Volume anual de água turbinado $\left(\mathrm{m}^{3}\right)$

$\mathrm{W}=$ Energia anual produzida $(\mathrm{KWh})$

$\mathrm{H}=$ Altura de queda máxima (m)

Atrelado ao volume acima é aplicado um fator de uso (FU), dado por:

$$
\begin{aligned}
& \mathrm{FU}=\mathrm{H} \cdot 6,5 \cdot 10^{-5} \quad\left(\text { para } \mathrm{V} \leq 50 \mathrm{Mm}^{3}\right) \\
& \mathrm{FU}=\mathrm{H} \cdot 33,7 \cdot 10^{-5} \quad\left(\text { para } \mathrm{V}>50 \mathrm{Mm}^{3}\right)
\end{aligned}
$$

O valor unitário aplicado junto ao volume resultante é o mesmo utilizado para a cobrança pela captação. Percebe-se que este tipo de cobrança (sobre a modificação do regime das águas) torna-se interessante frente às argumentações que consideram a água para a geração de energia um uso não consuntivo e, assim, isento de cobrança.

Por último, tem-se o coeficiente ambiental “A”, usado para diferenciar o meio receptor na diluição de poluentes quando do lançamento de cargas poluidoras, que pode variar de 1,4 - para corpos com bom padrão de qualidade - a 1,0 - para corpos com padrão de qualidade mais comprometido. No caso da captação, a variável "U” já considera a qualidade do corpo receptor. Nestes casos, são cobrados valores mais altos para captações em trechos de montante, onde as águas costumam ser menos poluídas. Dessa forma, o coeficiente “A” não compõe o valor cobrado para captação. (LANNA, 1999; SEROA DA MOTTA, 1998)

Percebe-se que o coeficiente ambiental é aplicado com maior incidência sobre usuários que utilizam corpos de água com qualidade ambiental melhor. Desta forma, evidencia-se um contra-senso, pois a cobrança deveria refletir a escassez relativa. $\mathrm{Ou}$ 
seja: as águas com capacidade de depuração maior (boa qualidade ambiental) devem ser taxadas de maneira módica em relação a corpos de baixa qualidade ambiental (saturados ou próximos à saturação).

A maneira como o coeficiente ambiental é aplicado pode incentivar os usuários a localizarem-se em meios já saturados. Mesmo que o custo de oportunidade de uma água de boa qualidade seja maior (fato que justificaria a utilização de um coeficiente ambiental maior), pode-se questionar a oportunidade perdida de se transformar uma água de qualidade inferior em outra de qualidade superior. Da maneira como o coeficiente ambiental é empregado, a tendência é dividir os corpos de água em duas classes: “águas especiais” e “esgotos a céu aberto”.

Percebe-se que para corrigir a distorção mencionada acima é preciso dispor de outros instrumentos como a outorga, o zoneamento e o Estudo de Impacto Ambiental (EIA). Entretanto, se o coeficiente ambiental de fato refletisse a escassez relativa, a cobrança poderia ser um instrumento indutor do ordenamento da ocupação e uso do solo, pois existe uma estreita relação entre a ocupação territorial e a qualidade das águas. Neste caso, a implementação da cobrança estimularia a melhor localização das atividades, respeitados os padrões de qualidade que, por sua vez, deve refletir uma situação ecológica sustentável.

Um semelhante contra-senso é observado para o caso da variável "U” quando da cobrança sobre captação. Ao determinar valores maiores para zonas da bacia onde a água apresenta maior qualidade (trechos de montante), na prática, a cobrança pode corresponder a incentivo para instalação de atividades onde o recurso natural já se encontra próximo ao nível de saturação; portanto, apresenta maior escassez relativa (trechos de jusante). Mesmo que a jusante a disponibilidade quantitativa seja maior, um incentivo à concentração de atividades nessas áreas pode ser prejudicial.

CHAPUY* $^{*}$ apud SEROA DA MOTTA (1998), ao analisar os resultados da implementação deste sistema de cobrança na França, verificou que os investimentos elevaram a taxa de tratamento de efluentes domésticos de cerca de 50\% em 1982 para mais de $72 \%$ em 1992. Simultaneamente, a indústria reduziu as emissões de carga orgânica em cerca de 27 \% e de sólidos suspensos e material tóxico em 38 \%.

\footnotetext{
* CHAPUY, P. (1996). Evaluation de l'efficacité et le l'éfficience des systemmes de redevance de pollution de l'eau: étude de cas de la France. Direction de L'Environment, OECD.
} 
Como mencionado, a melhoria ocorreu mais em razão de investimentos tecnológicos e pouco em função do valor ambiental assumido pelos usuários do sistema.

Uma das possíveis explicações para esta realidade está no fato de o sistema de cobrança empregado na França - apesar de trazer embutidos critérios que levam em conta a escassez relativa dos recursos, a racionalização do uso e a melhor alocação dos usuários, tais como: tipo de usuário, localização, sazonalidade, capacidade de assimilação (aplicada de forma equivocada) e o tipo de efluente - ter como finalidade última cobrir custos financeiros de infra-estrutura na bacia hidrográfica, ao invés de apresentar valores incitativos de comportamento racional em relação à utilização dos recursos hídricos.

\subsection{Caso da Alemanha}

Na Alemanha a gestão dos recursos hídricos é caracterizada pelo federalismo conseqüência da diversidade de culturas regionais, e pelo princípio da subsidiaridade. A gestão é realizada principalmente no âmbito dos Estados (Länder), diferentemente da França que possui como unidade administrativa as bacias hidrográficas*. O poder e a capacidade administrativa se estendem também aos municípios, baseado no princípio constitucional de autonomia municipal, que garante gestão descentralizada e integrada do solo e da água.

Atribui-se aos municípios o controle dos interesses locais, dentre os quais está a obrigação de promover condições adequadas de vida, por meio da gestão de serviços públicos como abastecimento de água e a coleta de lixo. Assim, eles dispõem de um grande grau de liberdade na escolha do próprio arranjo institucional e organizacional, normalmente restrito a cada municipalidade ou associado a outras, ou à companhias públicas e empresas privadas. (KRAEMER, 1999)

Percebe-se que o princípio da subsidiaridade carrega a tomada de decisão para esferas administrativas menores e descentralizadas. Este aspecto auxilia na solução rápida de problemas locais e facilita a participação da sociedade. KRAEMER (1999) comenta que a participação na gestão das águas e a cooperação entre os municípios são funções exercidas por meio de associações do solo e da água, de agricultores, de

\footnotetext{
* A única exceção, na Alemanha, é a Bacia do Rio Ruhr.
} 
empresas privadas, de corporações públicas e de profissionais. Nessas associações são alocadas determinadas tarefas que podem ser restrita a uma pequena área rural ou abranger grandes territórios.

O sistema alemão de gerenciamento das águas foi instituído pela Lei Federal de Recursos Hídricos de 1957 (revisada em 1996). Essa lei definiu que a competência legislativa relativa à política das águas - antes limitada aos Estados - passasse a ser também da Federação. Portanto, caberia aos Estados completar e reforçar, mas não atenuar a legislação federal. (BARRAQUÉ, 1995; SEROA DA MOTTA, 1998)

Desta maneira, a intervenção federal no âmbito legislativo foi reforçada com a criação do Ministério do Ambiente, Proteção da Natureza e Segurança Nuclear. No que diz respeito às águas cabe, à administração central, a responsabilidade pela revisão e aplicação da lei federal de gestão das águas de 1957 e da lei sobre as taxas de poluição de 1976. Essas funções são realizadas pela atuação das agências técnicas do ambiente e da proteção da natureza.

O Ministério Federal do Ambiente conta com outros parceiros para a aplicação de programas e projetos de gestão das águas: Ministério Federal da Alimentação, Agricultura e Silvicultura - que propõe projetos no setor rural (inclusive de proteção contra inundações) e é, ainda, o responsável pela legislação que regula a atuação das associações de gestão das águas; Ministério Federal da Saúde - responsável pela qualidade da água potável e das águas de banho; Ministério Federal dos Transportes - que regula a utilização das vias navegáveis e, juntamente com as regiões costeiras, combate a poluição das águas marinhas; Ministério da Economia - que salvaguarda os interesses econômicos das medidas necessárias à gestão do ambiente. (FEDERAL MINISTRY FOR THE ENVIRONMENT, NATURE CONSERVATION AND NUCLEAR SAFETY, 1998)

Apesar de a competência legislativa ser concorrente cabe, exclusivamente aos Estados e Municípios, a implementação das políticas de proteção e gestão das águas. Sobre a competência interna aos Estados, BARRAQUÉ (1995) comenta o fato deles terem estruturas institucionais diferenciadas e afirma, também, que a maior parte possui um Ministério do Ambiente responsável por recuperar a qualidade das águas, enquanto outros - segundo o autor, partindo do conceito de proteção da natureza confiaram o ambiente ao Ministério da Agricultura. 
Na maioria dos Estados a estrutura administrativa referente à gestão das águas se divide em três níveis: a Autoridade Inferior da Água - representada pelas cidades e encarregada das licenças e autorizações para pequenos usuários, monitoramento, aconselhamento técnico, etc; a Autoridade Superior da Água - confiada aos distritos e responsável pela maior parte das licenças, monitoramento e implementação dos planos regionais de gestão das águas; a Autoridade Suprema da Água - geralmente concedida ao Ministro do Ambiente do Estado responsável pela política das águas. Cabe observar que nas cidades-Estado de Berlim, Bremem e Hamburg, a estrutura administrativa das águas é diferenciada e mais simples que as demais. (FEDERAL MINISTRY FOR THE ENVIRONMENT, NATURE CONSERVATION AND NUCLEAR SAFETY, 1998)

Independente da estrutura administrativa diferenciada por Estados, com relação ao domínio sobre as águas, em toda a Alemanha, as águas superficiais e subterrâneas são consideradas bens comuns e são apropriáveis somente até o ponto de não lesarem os vizinhos ou outros habitantes ribeirinhos. Desta forma, todos os usos da água necessitam de licença, considerada instrumento primário de gestão das águas na Alemanha. O sistema de licenças estabelece o direito a um específico uso de água, quando os efeitos no corpo de água são bem conhecidos, e sua recusa segue objetivos de qualidade da água. (KRAEMER, 1999)

A respeito das licenças, BARRAQUÉ (1995) afirma que em 1957 a autorização era concedida levando-se em conta uma abordagem por captação, ou seja, a retirada não poderia comprometer a qualidade da água desejada para o corpo hídrico (padrão de qualidade), mas permitia descargas em águas fortemente poluídas. O autor relata que somente em 1976, quando a preocupação voltou-se para o estabelecimento de padrões de emissão, foi introduzida a abordagem por lançamento de poluentes e, a partir de então, foi dada prioridade ao princípio de prevenção e ao poluidor pagador.

Além do sistema de licenças, a lei de 1957 adota uma gama de instrumentos de comando e controle - considerados nos planos diretores de gestão das águas e planos de gestão das águas - planos que visam, prioritariamente, a proteção dos corpos de água superficiais, não a gestão quantitativa das águas. Alguns instrumentos adotados são: planos de descarga de efluentes; planos de controle das cargas de efluentes; regulamentos de proteção da águas superficiais; zonas de proteção das águas. 
Dentre os instrumentos listados, o emprego de zonas de proteção das águas tem se mostrado eficaz na preservação de águas destinadas ao abastecimento, na recarga de águas subterrâneas e na prevenção da poluição difusa. Nessas áreas, determinadas atividades podem ser restringidas e até proibidas, e os proprietários são obrigados a tolerar o monitoramento. (KRAEMER, 1999)

Apesar dos avanços na política das águas, proporcionados pela lei de 1957, somente em 1976 houve forte preocupação com o estado das águas já comprometidas pelos lançamentos de efluentes. Assim, surgiu a discussão acerca da cobrança sobre usos da água, o que reforçou a intervenção federal nas políticas de recursos hídricos. Segundo SEROA DA MOTTA (1998), a cobrança foi definida na forma de uma taxa federal, administrada pelos Estados e aplicada sobre lançamento de efluentes de usuários urbanos e industriais.

Atualmente, a cobrança é largamente empregada na Alemanha, tanto no âmbito federal como no estadual e municipal. Efetuada sobre a captação e o lançamento de efluentes, a cobrança possui diferentes valores entre as unidades administrativas. Sua adoção serviu para reduzir o “déficit de implementação” de políticas ambientais que usavam somente instrumentos de regulação direta. Neste contexto, o instrumento econômico passou a funcionar juntamente com o sistema de licenças, e a arrecadação a ser utilizada na melhoria da qualidade da água. (KRAEMER, 1999)

O autor op cit. resume em seis pontos os efeitos da introdução da cobrança sobre usos da água na Alemanha:

- Proporcionou aos ministérios do ambiente dos Estados fonte financeira que ajudou a capacitar o pessoal necessário à administração das águas;

- Supriu recursos financeiros para implantação de atividades necessárias à gestão das águas;

- Fortaleceu os sistemas de informações das autoridades da água, forçando a freqüentes renovações das informações e documentação relativa à descarga de efluentes, captação de água e outros usos da água;

- Introduziu na relação entre os gestores das águas e os diversos usuários: um novo componente financeiro que ajudou a mudar e intensificar essa relação; 
- Atrelados ao aumento da receita, introduziu elementos de controle e coação, que ajudaram a formalizar e fortalecer a posição da administração em caso de conflitos;

- Promoveu a revisão das necessidades de água e dos direitos de propriedade adquiridos, do potencial de economia da água e de redução da poluição.

É interessante perceber que as conseqüências da implantação da cobrança são mais de ordem financeira, que de incentivo à economia de água ou diminuição da poluição.

\subsubsection{Formação do valor cobrado na Alemanha}

\subsubsection{Cobrança sobre captação}

A cobrança sobre a captação é empregada em diversas regiões da Alemanha, como Berlim, Hamburg, Hessen e Lander. O valor é baseado no volume retirado, no tipo de fonte (superficial ou subterrânea) e no uso final do recurso hídrico (irrigação, abastecimento público, etc). As retiradas inferiores a $2.000 \mathrm{~m}^{3} /$ ano são isentas de cobrança. (LANNA, 1999)

Percebe-se que o sistema de cobrança sobre a captação carece de fatores que considerem a escassez do recurso, pois os critérios parecem ser uniformes para todas as regiões e não leva em conta nem a sazonalidade nem as especificidades locais. A justificativa para essa constatação parece estar no sistema de licenças que, no caso de captação, leva em consideração os objetivos de qualidade da água.

Geralmente, os valores mais elevados são aplicados sobre a água subterrânea, especialmente para usos que não sejam o de abastecimento público. Nos Estados de Hamburg e Hessen, por exemplo, a cobrança é efetuada apenas sobre captações subterrâneas. Assim, podem ser citadas algumas conseqüências do nível incitativo do valor cobrado pela captação: devolução, por parte dos usuários, do direito de uso da água subterrânea, fato ocorrido em Hamburg; decréscimo do uso pelas indústrias que passaram a reciclar a água nos seus processos; e uso mais eficiente por parte dos usuários domésticos e pequenos comércios. (KRAEMER, 1999; ZABEL et al., 1999) 
O fato de a água subterrânea possuir um valor mais alto de cobrança é coerente com o princípio de escassez relativa, pois incentiva o uso da água superficial, recurso que possui maior capacidade de renovação. Existe, ainda, o aspecto de racionalização do uso da água, que resguarda um recurso de alta qualidade para usos mais nobres. Dentre estes cita-se, como exemplo, o abastecimento público.

Com relação aos recursos arrecadados pela cobrança sobre captação, pode-se afirmar que em muitos casos eles são utilizados para compensar os agricultores pelas restrições das zonas de proteção, e para subvencionar os usuários que economizam água. Além disso, no Estado de Baden-Württemberg, por exemplo, os recursos são utilizados para compensar agricultores pelo efeito da redução do uso de fertilizantes e pela aplicação de agrotóxicos mais caros, mas menos agressivos ao ambiente, que protege usos como a captação para abastecimento. Apesar de esse tipo de subsídio trabalhar no sentido oposto ao princípio poluidor pagador, caso seja adequadamente aplicado pode ser mais barato (custo-efetivo) do que o incremento no tratamento de água. (KRAEMER, 1999; ZABEL et al., 1999)

Cabe destacar que as compensações aos proprietários de terra, pela manutenção das matas ciliares, retratam a integração do sistema de gestão. Existe, portanto, uma estreita relação entre a gestão das águas e a de uso do solo. Vale ressaltar, ainda, a utilização de recursos arrecadados com a cobrança, na manutenção de um sistema de bonificação para aqueles usuários que conseguem maior eficiência no uso do recurso e empregam tecnologias limpas, isto é, tecnologias mais adequadas ambientalmente.

\subsubsection{Cobrança sobre lançamento de efluentes}

A cobrança sobre lançamento de efluentes, na maioria dos Estados, foi iniciada em 1981. Ela está atrelada ao sistema de licenças que, para esse caso, estabelece o padrão de emissão para estações de tratamento de esgotos urbanos e usos industriais específicos, partindo da premissa de utilização da "melhor tecnologia disponível”, ou seja, o padrão de emissão tem por base a eficiência do melhor sistema de tratamento possível para determinado poluente. (ZABEL et al.,1999)

Quando os lançamentos industriais atingem os padrões de emissão, os valores cobrados são reduzidos em 50\%; para o caso dos sistemas de tratamento municipais a 
redução é de $15 \%$. As municipalidades que investem no melhoramento das estações de tratamento recebem 3 (três) anos de isenção da cobrança, desde que obedeçam aos padrões de emissão estabelecidos. Esses descontos e subvenções, até certo ponto, incorporam grandes incentivos à redução das concentrações. (ECOTEC RESEARCH \& CONSULTING, 2001)

Esse sistema de cobrança sobre o lançamento de efluentes considera o volume e a concentração do poluente. Cada tipo de poluente possui sua respectiva unidade de poluição (TABELA 4), e a cobrança é efetuada sobre a quantidade de unidades de poluição contidas no efluente. O valor pago pela unidade de poluição tem aumentado no decorrer dos anos, em 1981 era de US\$ 6,70; em 1993 de US\$ 33,7 e em 1997 o valor chegou a US\$39,3. (LANNA, 1999; SEROA DA MOTTA, 1998)

TABELA 4 - Poluentes e respectivas unidades de poluição.

\begin{tabular}{l|l}
\hline \multicolumn{1}{c|}{ Poluentes } & Uma unidade de poluição corresponde a: \\
\hline Substâncias Oxidáveis (DQO) & $50 \mathrm{~kg}$ de oxigênio. \\
Fósforo & $3 \mathrm{~kg}$ \\
Nitrogênio & $25 \mathrm{~kg}$ \\
$2 \mathrm{~kg}$ de alógeno, calculado como cloro \\
Compostos Orgânicos Alógenos (AOX) \\
orgânico ligado \\
20 gr \\
Mercúrio & 100 gr \\
Cádmio & 500 gr \\
Cromo & 500 gr \\
Níquel & 500 gr \\
Chumbo & 1000 gr \\
Cobre & $\begin{array}{l}3.000 \mathrm{~m}^{3} \text { de águas servidas divididas pelo } \\
\text { fator de diluição G quando estas não } \\
\text { contêm mais toxicidade para os peixes. }\end{array}$ \\
\hline
\end{tabular}

Fonte: Federal Ministry for the Environment, Nature Conservation and Nuclear Safety (1998).

É interessante observar que, a partir dos critérios adotados por este sistema de cobrança, demonstra-se que em momento algum é considerada a capacidade de assimilação do corpo receptor, uma vez que a observância do padrão de emissão, de 
maneira isolada, não garante o atendimento do padrão de qualidade do corpo d’água. Ao não considerar a escassez relativa da água e, também, por ser adotado de maneira uniforme para toda a federação - sem observar as especificidades locais - a atuação desse sistema de cobrança é questionável como instrumento econômico de gestão, pois negligencia o padrão de qualidade do ambiente aquático, requisito crucial para o estabelecimento do uso sustentável da água.

Apesar das deficiências, verifica-se que após a implementação da cobrança em 1981, as descargas de efluentes industriais diminuíram cerca de 31\% até 1995. BUCKSTEEG* apud ECOTEC RESEARCH \& CONSULTING (2001) comenta que muitas indústrias preferiram melhorar os processos produtivos em favor da economia de água, a arcar com os custos de sistemas de tratamento de efluentes. $\mathrm{O}$ gasto das indústrias com a cobrança é cerca de $3 \%$ do montante total por elas investido no controle da poluição das águas. De acordo com KRAEMER (1999), esses resultados e incentivos à racionalização do uso da água devem ser creditados aos altos valores cobrados, que sistematicamente têm sido incrementados, ao longo do tempo.

O produto da cobrança pelo lançamento de efluentes tem sido empregado na melhoria da qualidade da água. Embora a cobrança possua caráter incitativo, sua função de financiamento se sobressai e seu papel fiscal é reduzido. Em torno de 10 a 20\% da arrecadação são gastos na administração do sistema e o restante é utilizado pelos Estados para financiamento dos investimentos municipais em tratamento de efluentes. (KRAEMER, 1999; SEROA DA MOTTA, 1998)

Apesar de ser mais notória a função de financiamento exercida pela cobrança, as autoridades alemãs acreditam que esse sistema seja um incentivo maior à redução da poluição pontual que as abordagens de comando e controle - como as licenças para lançamentos. (KRAEMER, 1999)

Percebe-se que apesar dos incentivos que o sistema de cobrança sobre usos da água tem fornecido, o aspecto de arrecadação suplanta o de racionalização do uso. Mesmo que ela seja alcançada devido aos altos valores cobrados, como a formação desses valores considera premissas descoladas da qualidade ambiental desejada -

\footnotetext{
* BUCKSTEEG, K. (1991). Water Resources Management and Water Pollution Control: National Case Studies from the Federal Republic of Germany, European Water Pollution Control, vol. 1, no. 4, pp. 34-44.
} 
apesar de eles aumentarem sistematicamente - futuramente poderão estar defasados daqueles que refletiriam o real valor do recurso hídrico.

Atualmente, a Alemanha se preocupa com a diminuição da poluição difusa e o controle das inundações. No combate à poluição difusa agrícola, tem sido eficaz o papel do sistema de licenças, da cobrança e das zonas de proteção. No entanto, ainda falta maior integração entre a política de gestão das águas e outras políticas públicas, principalmente do setor agrícola. Para controle das inundações, municipalidades têm aplicado cobrança sobre áreas superficiais impermeabilizadas, o que tem incentivado o emprego de superfícies que permitem infiltração, como as pedras porosas. (KRAEMER, 1999)

\subsection{Caso da Inglaterra e do País de Gales}

Inglaterra, País de Gales e Escócia são países que, em conjunto, formam a GrãBretanha. Nos dois primeiros países a política de recursos hídricos segue os mesmos princípios e objetivos, já a Escócia possui política diferenciada e independente. A análise aqui proposta tratará da política de gestão das águas na Inglaterra e País de Gales, pois, nesses dois países, ela possui características peculiares e abrange cerca de $90 \%$ da população britânica.

Um relato histórico da progressiva mudança do sistema de gestão das águas na Inglaterra e País de Gales retrata o caminho percorrido, e é subsídio ao entendimento de sua atual Política das Águas.

\subsubsection{Histórico}

Do início do século XX, até os anos 20, a gestão das águas inglesas era feita no âmbito das coletividades locais. De maneira descentralizada, os gestores procuravam atender às necessidades locais e contavam com a ativa participação das comunidades.

A partir dos anos 30 houve progressiva diminuição das responsabilidades locais na gestão dos recursos hídricos. Já em 1945, uma grande reforma administrativa (fusão dos municípios) diminuiu consideravelmente o número de administradores das 
redes de abastecimento e saneamento, fato que fez evoluir, ainda mais, o processo de centralização das responsabilidades antes exercidas pelas coletividades locais.

No decorrer das décadas de 50 e 60 a fusão dos municípios progrediu, e cresceu a tendência à formação de regiões administrativas. Este aspecto, em 1974 repercutiu com a criação de 10 Regional Water Authorities (RWA), cujas delimitações seguiam as das bacias hidrográficas. Cabe destacar que a regionalização, entre outros fatores, foi motivada pela preocupação eminente com a escassez verificada, principalmente, em relação às águas superficiais e à necessidade de gestão integrada.

BARRAQUÉ (1995) comenta que a escassez dos recursos hídricos superficiais era fonte de preocupação desde 1945 e que, com objetivo de tratar essa questão, naquele ano instituiram-se os Conselhos de Rio (River Boards), encarregados de gerir o uso da água e, possíveis conflitos de uso e controle da poluição. Ressalta-se que, naquela época, os eleitos locais detinham 60\% dos assentos dos conselhos.

Como mencionado, com a regionalização ocorrida em 1974, a água passou a ser gerida no âmbito das bacias hidrográficas. Praticamente toda a gestão das águas ficou sob a incumbência das Regional Water Authorities (RWA), encarregadas das seguintes funções: financeira, gerencial, de fiscalização (controle da poluição), de construção, operação e manutenção da infraestrutura sanitária. O marco legal que deu origem a essa reestruturação foi o Water Act de 1974, que criou, ainda, o Conselho Nacional da Água (National Water Council) - responsável pela harmonização das ações das administrações de bacia, além do Gabinete de Equipamento dos Espaços Aquáticos (Water Space Amenity Commission) que detinha o papel de consultor para utilização recreativa das águas.

Com o resultado obtido pela regionalização, destaca-se o aumento da eficácia dos serviços de abastecimento, o desenvolvimento da gestão integrada das águas e a melhoria da qualidade de alguns cursos d’água. De acordo com BARRAQUÉ (1995), apesar dos bons resultados, o sistema adotado possuía deficiências. Com relação ao controle da poluição se observava, por exemplo, que as RWA eram ao mesmo tempo “juiz e parte”, pois eram encarregadas de controlar os lançamentos de efluentes delas mesmas. Ou seja, não existia diferença entre regulador e regulado.

A partir de 1974, no decorrer dos anos, a lógica de funcionamento das $R W A$ voltava-se para eficácia de mercado. BARRAQUÉ (1995) observa que, inicialmente, 
a maioria dos assentos no conselho de administração das $R W A$ era de eleitos locais. Entretanto, com a chegada ao poder do governo Thatcher, essa cota diminuiu para $40 \%$ e, a partir de 1983, para zero. A intenção era fazer com que os usuários e as coletividades locais fossem representados por associações de consumidores e não pelos eleitos locais.

Assim, em 1989 as instalações e funções das RWA relativas aos serviços de distribuição de água potável, saneamento e tratamento de águas residuárias foram privatizadas e transferidas à 10 Water Services Companies (WSC), por um período de 25 anos. Na mesma época, a gestão e a política das águas foram confiadas a National Rivers Authority (NRA) que, em conjunto com o Office of Water Services (OFWAT), era responsável pela regulação econômica, controle dos resultados e defesa dos consumidores das companhias de saneamento básico. Por sua vez, o Drinking Water Inspectorate (DWI) era encarregado de verificar a quantidade e qualidade da água distribuída pelas companhias. Assim, a partir de 1989 estes três organismos públicos independentes passaram a formar o âmbito central de gestão dos recursos hídricos na Inglaterra e País de Gales.

A promulgação do Water Resources Act de 1991 reafirmou o papel central da National Rivers Authority (NRA) na gestão das águas. Sua atuação compreendia as dez regiões administrativas herdadas da Regional Water Authorities, que passaram a ser oito após 1993, devido à fusão das regiões Wessex e South-West; além de Northumbrian e Yorkshire.

Finalmente, em 1996, ocorreu a última reforma institucional relativa à gestão das águas. A NRA fundiu-se com a Her Majesty's Inspectorate of Pollution (HMIP) - corpo técnico responsável para controlar e autorizar os lançamentos de substâncias industriais perigosas; e com as Waste Regulation Agencies - responsáveis locais pela gestão de resíduos. Essa fusão resultou na Environment Agency (EA), que passou a ser a principal instituição encarregada da implementação da política de gestão ambiental e em particular da política das águas. (ZABEL \& REES, 1999) 


\subsubsection{O presente}

A atual gestão de recursos hídricos na Inglaterra e País de Gales adota a bacia hidrográfica como unidade administrativa, e distingue oito regiões administrativas. A legislação recente que trata da política das águas é o Water Resources Act de 1991, o qual consolidou o sistema de gerenciamento dos recursos hídricos, cujo responsável principal era o Nacional Rivers Authority (NRA), e que em 1996 passou suas funções à responsabilidade da Environment Agency (EA).

ZABEL \& REES (1999) comentam que a atual estrutura do sistema de gestão das águas inglesas é centralizada e permite que as políticas, legislações e regulações sejam coordenadas no âmbito nacional sem pressões políticas locais. A ausência do controle local nas políticas ambientais é, de certa forma, compensada pela consulta pública relativa aos objetivos de qualidade ambiental desejados, por meio de comitês consultivos, pesquisas públicas, etc.

Além dos mecanismos de participação da sociedade civil já mencionados, verifica-se que o interesse da escala local na gestão das águas tem sido considerado na elaboração de Local Environment Agency Plans (LEAPs) - espécie de plano de bacia derivado dos antigos Catchment Management Plans (CMPs), os quais foram formulados para a maioria dos rios da Inglaterra e País de Gales pela NRA. Os LEAPs funcionam como referências para as tomadas de decisão, pois consideram além de uma análise do estado das águas em termos de oferta, demanda e qualidade também as propostas sugeridas por grupos de usuários e instituições governamentais. Apesar de os LEAPs fornecerem subsídios ao gerenciamento de bacias hidrográficas, há pouca interface com o planejamento de uso do solo. (MOSTERT, 1999; ZABEL \& REES, 1999)

Os objetivos de qualidade dos meios aquáticos são o cerne principal do sistema de gestão das águas na Inglaterra e País de Gales. As políticas e suas implementações possuem um elevado nível de integração. A Environment Agency (EA) em conjunto com o OFWAT e com DWI são responsáveis pela implantação da política das águas elaborada pelo Department of the Environment, Transport and the Regions (DETR).

Além do DETR, a Environment Agency (EA) está subordinada ao Ministry of Agriculture, Fisheries and Food. As atribuições da EA relativas às águas são: 
controle da poluição; luta contra inundações; controle da pesca, da navegação e dos usos recreativos; e conservação da natureza aquática. É importante destacar que sua atuação cobre todos os ambientes aquáticos desde rios, lagos, reservatórios, até águas costeiras, estuários e águas subterrâneas. (ZABEL \& REES, 1999)

É interessante mencionar que a atuação da $E A$ se dá no sentido de regular a utilização dos ambientes aquáticos. Para tanto, a instituição contou com a mudança relativa ao domínio das águas que, de início, respeitava os direitos dos proprietários ribeirinhos. A esses usuários era concedida a liberdade para usar a água, desde que a deixassem em quantidade e qualidade equivalentes aos proprietários de jusante e restringissem o uso das águas aos limites físicos de suas terras. A mudança ocorreu quando as RWA adotaram o sistema de autorizações para usos da água. Assim, o domínio das águas passou a ser baseado no direito de uso e não de apropriação, seja pública ou privada. Portanto, usos como captação, pesca, navegação e lançamento de águas residuárias necessitam de licença, ela somente é dispensada para volumes menores que $20 \mathrm{~m}^{3} / \mathrm{dia}$. (BARRAQUÉ, 1995)

O controle da poluição é exercido por meio do sistema de licenças concedidas pela $E A$. Esse sistema, que existe desde 1965, é o principal instrumento utilizado no controle dos usos da água. A licença funciona como uma outorga do direito de uso da água concedida ao usuário, e considera os objetivos de qualidade do corpo de água estabelecidos com a utilização de dois parâmetros. O primeiro define o uso da água (Environmental Quality Objective) e o outro fixa o padrão de qualidade da água para o uso requerido pelo primeiro (Environmental Quality Standard). (ZABEL \& REES, 1999)

Atrelado ao sistema de licenças está a cobrança sobre usos da água, a qual é efetuada sobre captação de água bruta e lançamento de águas residuárias. O atual sistema de cobrança é regulado pelo Water Resouces Act de 1991 e pelo Environment Act de 1995. A aplicação da cobrança teve início em abril de 1993 sob administração da Nacional Rivers Authority (NRA).

Os recursos obtidos com a cobrança normalmente são utilizados para cobrir custos administrativos da Environment Agency no cumprimento das funções relativas à gestão das águas. Citam-se: manutenção do sistema de licenças e monitoramento da qualidade da água. Ao basear-se em custos administrativos e subestimar o real valor 
do recurso hídrico, os valores cobrados são considerados baixos e não induzem a comportamento racional no consumo da água. (LANNA, 1999; ZABEL et al., 1999)

Percebe-se que a finalidade maior do sistema de cobrança é a recuperação dos custos administrativos. Seu papel como instrumento de gestão tem sido relegado a segundo plano, apesar de alguns parâmetros da formulação dos valores considerarem a escassez relativa da água. Embora exista referência aos preceitos da escassez, a aplicação do modelo proposto deixa a desejar, pois se alguns parâmetros penalizam o usuário e o incentivam ao uso correto da água, outros o desencorajam, não só pelo valor atribuído, mas também por seu modo de aplicação. Estas observações estarão mais claras com a análise da formação dos valores da cobrança.

\subsubsection{Formação do valor cobrado na Inglaterra e País de Gales}

O sistema de cobrança sobre usos da água na Inglaterra e País de Gales possui dois elementos. O primeiro é a Application Charge - valor cobrado quando da solicitação da licença; o segundo é a Annual Charge - valor cobrado anualmente sobre captação de água bruta e lançamento de efluentes líquidos em corpos hídricos.

Na cobrança sobre usos da água, existem alguns usuários e usos isentos de pagamento. Citam-se: a captação de água subterrânea para agricultura que não utilize irrigação por aspersão e não exceda 20 m³/dia; utilização da água para geração de energia elétrica cuja capacidade não ultrapasse cinco megawatts; captação de águas interiores, certificadas pela $E A$, com conteúdo médio de cloretos superior a 8.000 mg/L. (ENVIRONMENT AGENCY, 2000)

\subsubsection{Cobrança sobre captação}

A cobrança anual sobre o uso da água é calculada por meio da equação (5).

Cobrança Anual $=$ V . F . B . C . SUC

Onde:

Cobrança Anual = Valor anual pago sobre captação (Libras)

$\mathrm{V}=$ Volume outorgado pela licença $\left(\mathrm{m}^{3}\right)$ 
$\mathrm{F}=$ Fator de fonte

$\mathrm{B}=$ Fator sazonal

$\mathrm{C}=$ Fator de perda

SUC = Standard Unit Charge (Cobrança Unitária Padrão) $\left(\right.$ Libras $\left./ \mathrm{m}^{3}\right)$

Observa-se que a formulação apresentada, ao considerar fatores que observam os preceitos da escassez, poderia atuar como mecanismo regulador de apropriação da água e estimular a melhor localização espacial das atividades. Entretanto, não se verifica essa atuação na Inglaterra e País de Gales, devido à desconsideração do real valor ambiental da água e à preocupação com recuperação de custos administrativos.

Primeiramente, cabe observar que a cobrança anual sobre captação tem por base o volume outorgado pela licença "V", e não a quantidade realmente consumida. Esta situação pode incentivar o uso dispendioso do recurso hídrico, ou seja, o usuário poderá consumir até o limite da outorga, mesmo que não necessite. Além disso, não incentiva a adoção de tecnologias ambientalmente adequadas, como: irrigação por gotejamento, reuso e processos industriais mais eficientes, uma vez que não é dada ao usuário a oportunidade de pagar sobre o que ele realmente consome ou poderá vir a consumir durante o período de vigência da licença.

O fator de fonte "F” diferencia três tipos de fontes de água, incluídas as águas subterrâneas. Fontes tipo Unsupported são aquelas não assistidas pela EA; fontes tipo Supported são diretamente controladas pela EA (a adição de outras fontes nesta categoria passa pela aprovação do Secretário de Estado); e fontes tipo Tidal - águas interiores que recebem influência das marés, tais como estuários. Os valores são: 1,0 para fontes Unsupported; 3,0 para fontes Supported; e 0,2 para fontes tipo Tidal. (ENVIRONMENT AGENCY, 2000)

É interessante destacar que para as fontes diretamente administradas pela $E A$ ocorre um aumento de $200 \%$ no valor da cobrança. Esta atribuição tem por finalidade a recuperação de custos com infraestrutura necessária à ampliação ou manutenção da oferta hídrica. Vale ressaltar, ainda, que o subsídio dado a usuários de águas que recebem influência das marés parece ser motivado pela grande variação sazonal da qualidade da água em curtos períodos de tempo. Apesar dessa consideração, observase que o fator de fonte " $F$ " retrata mais aspectos administrativos. 
O fator sazonal "B" também é diferenciado em três categorias, e considera o período do ano em que ocorre a captação. Assim, de 31 de março a 01 de novembro é considerado verão e, nesse caso, o fator sazonal é 1,6; de 31 de outubro a 01 de abril, período inverno, o fator é 0,16; por último, existe o fator que considera a captação durante o ano todo cujo valor é igual a 1,0. (ENVIRONMENT AGENCY, 2000)

Vale ressaltar que a aplicação do fator sazonal neste sistema é coerente com o conceito de escassez relativa - independentemente do grau de penalidade. Em épocas de stress hídrico é justo que se pague mais pela oferta de água, não apenas pela diminuição da oferta hídrica em si, mas também como forma de gerir os conflitos que possam existir em um cenário de escassez. Fatores indutores de comportamento racional com relação ao consumo de água - como é o caso do fator sazonal para o verão, poderiam até mudar toda uma estrutura produtiva em benefício da qualidade ambiental desejada.

O fator de perda “C” é usado para diferenciar que uso é feito da água, por meio da atribuição qualitativa da perda que pode ocorrer em determinados usos. São distinguidas quatro categorias: perda alta, perda média, perda baixa e perda muito baixa. Para cada categoria existem os usos associados. Assim, para perda alta, tem-se a irrigação por aspersão e usos que, devido à evaporação, comprometem o retorno direto ou indireto da água para a fonte de captação; para perda média, tem-se o abastecimento público ou privado, usos comerciais e industriais não especificados em outras categorias, caldeiras, uso da água como meio de transporte, usos que incorporem água ao produto, agricultura (exceto irrigação por aspersão, fazendas de pesca e watercress) e aspersão anticongelamento; já para a perda baixa, tem-se a lavagem de minérios, lavagem de vegetais e resfriamento não evaporativo; por último, para perda muito baixa, tem-se a geração de energia maior que 5 megawatts, piscinas naturais, experimentos hidráulicos, fazendas de pesca, watercress e diluição de efluentes. Usos não inseridos nas categorias referidas são considerados de perda alta, a não ser que a $E A$, baseada em informações do próprio usuário, determine outro fator. (ENVIRONMENT AGENCY, 2000)

Os valores são: 1,0 para perda alta, 0,6 para perda média, 0,03 para perda baixa e 0,003 para perda muito baixa. Qualquer que seja o uso, não existe possibilidade de sobretaxa, portanto, o incentivo é fornecido na forma de descontos. É interessante 
observar que caso os usos associados pudessem mudar de categoria, criaria incentivo à diminuição das perdas. Um rigoroso controle nas perdas de redes de abastecimento, com monitoramento constante e pronta recuperação dos pontos de vazamento, poderia melhorar a eficácia do abastecimento e, desta forma, justificaria a mudança para categoria mais módica. Entretanto, cabe mencionar que essa observação é de caráter técnico, pois normalmente a análise econômica é o ponto balizador para a tomada de decisão.

A cobrança unitária padrão (SUC) é diferenciada por região (TABELA 5) e representa os custos administrativos da $E A$ em cada região. Dentro de uma região os valores unitários são os mesmos, independentemente do grau de saturação específico de cada manancial. (LANNA, 1999; ZABEL \& REES, 1999; ZABEL et al.,1999)

TABELA 5 - Valores da cobrança unitária padrão (SUC) por região.

\begin{tabular}{c|c}
\hline Região & $\begin{array}{c}\text { Cobrança Unitária Padrão } \\
(\text { Libras/1000 m³ }\end{array}$ \\
\hline Anglian & 17,60 \\
Midlands & 10,55 \\
Northumbria ${ }^{\mathrm{a}}$ & 19,64 \\
North West & 10,12 \\
Southern & 14,01 \\
South West & 15,90 \\
Thames & 9,99 \\
Wessex $^{\mathrm{b}}$ & 14,90 \\
Yorkshire $^{\mathrm{a}}$ & 8,12 \\
Wales & 9,15 \\
\hline
\end{tabular}

${ }^{a}$ Componente da Região North West

${ }^{\mathrm{b}}$ Componente da Região South West

Fonte: ENVIRONMENT AGENCY (2000). 


\subsubsection{Cobrança sobre lançamento de efluentes}

A cobrança anual sobre lançamento de águas residuárias é calculada por meio da equação (6), de acordo com (LANNA, 1999; DETR, 1999):

$$
\text { Cobrança Anual }=\mathrm{CV} \text {. CE } . \mathrm{CR} \text {. ACFF }
$$

Onde:

Cobrança Anual $=$ Valor anual pago sobre o lançamento de efluentes (Libras)

CV = Coeficiente em função do volume máximo diário admissível de efluente

$\mathrm{CE}=$ Coeficiente em função do tipo de efluente

$\mathrm{CR}=$ Coeficiente dependente do corpo hídrico receptor

ACFF = Cobrança anual de referência (Libras/ano)

O coeficiente em função do volume máximo admissível de efluente "CV” varia de 0,3 - para volumes entre 0 e $5 \mathrm{~m}^{3}$ até 14 - para volumes superiores a $150.000 \mathrm{~m}^{3}$. Na TABELA 6 estão listados esses valores. A aplicação deste coeficiente penaliza fortemente aqueles que impõem carga poluidora elevada e fornece descontos àqueles que lançam pouco. Portanto sua atuação é coerente, por ser cobrado valor mais alto do usuário que requere serviço ambiental maior.

TABELA 6 - Coeficiente em função do volume de efluentes lançados “CV”.

\begin{tabular}{c|c}
\hline Volumes $\left(\mathrm{m}^{3} /\right.$ dia $)$ & Coeficiente "CV” \\
\hline De 0 até 5 & 0,3 \\
Maior que 5 até 20 & 0,5 \\
Maior que 20 até 100 & 1,0 \\
Maior que 100 até 1.000 & 2,0 \\
Maior que 1.000 até 10.000 & 3,0 \\
Maior que 10.000 até 50.000 & 5,0 \\
Maior que 50.000 até 150.000 & 9,0 \\
Maior que 150.000 & 14,0 \\
\hline
\end{tabular}

Fonte: DETR (1999). 
O coeficiente em função do tipo de efluente “CE” também varia entre 0,3 e 14 e depende da composição do efluente e não da concentração do parâmetro poluente. Na TABELA 7 são apresentados esses valores. A atuação é semelhante à do "CV”, pois penaliza mais aqueles que lançam compostos de degradação ou tratamento mais difícil, que podem comprometer, por mais tempo ou permanentemente, a qualidade do corpo hídrico receptor.

O coeficiente que depende do corpo hídrico receptor "CR" assume o valor de 0,5 para águas subterrâneas; 0,8 para as águas costeiras; 1,0 para águas superficiais e 1,5 para o caso de estuários. Percebe-se que a aplicação do coeficiente incentiva o despejo de águas residuárias em corpos de água subterrâneos, pois provê descontos àqueles que o fazem. Este aspecto é contrário ao que se poderia imaginar como uso sustentável das águas, porque as águas subterrâneas são mais vulneráveis à poluição por possuírem baixa capacidade de renovação. Ainda que $70 \%$ da captação para abastecimento na Inglaterra e País de Gales seja tomada em águas superficiais - fato que faz diminuir a capacidade de assimilação destas fontes de água - esse aspecto não justificaria a maneira como o “CR” é aplicado às águas subterrâneas.

TABELA 7 - Coeficiente em função do tipo de efluente "CE”.

\begin{tabular}{l|c}
\multicolumn{1}{c|}{ Tipo de efluentes } & Coeficiente “CE” \\
\hline Complexos orgânicos e pesticidas & 14,0 \\
Potencialmente tóxicos, metais, etc. & 5,0 \\
Carga orgânica/efluentes industriais & 3,0 \\
Efluentes industriais gerais & 2,0 \\
Provenientes de drenagem urbana & 1,0 \\
De pequeno efeito ambiental & 0,5 \\
De mínimo impacto ambiental & 0,3 \\
\hline
\end{tabular}

Fonte: DETR (1999).

A cobrança anual de referência “ACFF” (Annual Charge Financial Factor) é uniforme para todas as regiões. A atuação conjunta dos coeficientes descritos para o sistema de cobrança sobre o lançamento de efluentes reflete os custos administrativos 
da Environment Agency (EA) em relação ao controle da poluição - principalmente custos com monitoramento. Segundo ZABEL et al. (1999) o valor cobrado é mais elevado quanto maior for a dificuldade das análises necessárias ao monitoramento e o nível de saturação do recurso hídrico receptor. De acordo com o DETR (1999) o valor da cobrança anual de referência é de 415 Libras.

Segundo ZABEL \& REES (1999), 60\% dos custos administrativos da EA são recuperados na aplicação da cobrança sobre captação e lançamento de efluentes. Entretanto, os valores cobrados são baixos e têm comprometido a aplicação desse sistema como instrumento econômico de gestão das águas.

\subsection{Caso da Austrália}

A Austrália é uma federação constituída de Estados e Territórios. Essas duas esferas administrativas detêm a jurisdição sobre os recursos hídricos nelas inseridos. Assim, política e gestão dos recursos hídricos é realizada de maneira descentralizada, contando, inclusive, com participação em escala local. O governo federal não exerce controle direto sobre as águas, entretanto, exerce forte influência e colabora com os Estados na gestão dos recursos hídricos.

A política das águas na Austrália, até o final dos anos 70, era voltada para a gestão quantitativa - realizada principalmente por meio de reservatórios. A partir dos anos 80 começaram a ocorrer mudanças - fatores econômicos e ambientais passaram a ter importância relevante na gestão das águas, que agora persegue os preceitos de sustentabilidade.

Neste contexto, MALANO et al. (1999) comentam que antes dos anos oitenta havia pouca competição pelas águas, e questões relativas à sua escassez eram incomuns. Somente nos anos oitenta os gestores começaram a perceber que a água requeria métodos de alocação mais cuidadosos. Assim, o gerenciamento das águas australianas experimentou reformas profundas nas últimas duas décadas. Entre elas estão a reforma institucional e a confiança na utilização de instrumentos econômicos de gestão, atrelados a um sistema bem definido e executável de direitos sobre a água. 
PIGRAM (1998) ressalta que houve um desvio na conduta da gestão das águas, com a redução do emprego das soluções estruturais e o aumento da importância dada à gestão eficiente das estruturas existentes.

Um dos momentos que marca a reestruturação da administração dos recursos hídricos na Austrália é a publicação do relatório da Australian Industry Commission, a respeito dos recursos hídricos e disposição de efluentes líquidos, em 1992. Nele foram apresentadas as causas da ineficiência e da maneira insustentável que se encontrava o uso das águas naquele país. Como resultado deste processo, surgiram propostas para revisão da política das águas, seguidas pelo Council of Australian Governments (COAG) em fevereiro de 1994.

As ações previstas pelo COAG para a reforma da gestão dos recursos hídricos incluíam:

- Alocação de água para atendimento das necessidades ecológicas, admitindo a importância do balanço entre interesses econômicos e ambientais;

- Adoção da gestão integrada das águas em bacias hidrográficas;

- Reforma no preço das águas, considerando a total recuperação de custos, a remoção dos subsídios cruzados e um fundo para manutenção e renovação;

- Adoção do mercado das águas;

- Definição clara e consistente dos direitos de propriedade sobre as águas;

- Reforma institucional e organizacional;

- Ajuste das conseqüências estruturais e sociais relativas à reforma;

- Participação social e programas educacionais.

Outro marco importante na reforma da administração das águas na Austrália foi o apoio dado pelo COAG na implementação da National Competition Policy em abril de 1995. Essa política estimula a competição entre as empresas de todos os setores da economia - inclusive entre as estatais. Para isso, a política propôs: remover barreiras desnecessárias ao comércio e à competição; exigir que todos os negócios operassem sob as mesmas regras de mercado; permitir o ambiente de não competição, somente se de interesse público; e reduzir as regulações impostas pelos governos. No caso dos recursos hídricos, o COAG argumentava faltar um elemento de competição que induzisse à melhoria do atendimento ao consumidor e ao ganho de eficiência dos serviços de água. (PIGRAM, 1998) 
De acordo com PIGRAM (1998), as reformas estão em andamento em todos os Estados e Territórios, inclusive na bacia Murray-Darling (maior e mais importante bacia australiana, inserida em cinco Estados ou Territórios, cobrindo cerca de 14\% do continente australiano, com população entorno de dois milhões de pessoas). Entretanto, cada região apresenta arranjos e dinâmicas de gestão específicas, devido a distintas disponibilidades e usos da água encontrados em todo país. Neste contexto, pode-se citar o Estado de Victoria, pioneiro na reforma administrativa e a South Australia, precursora na adoção do mercado das águas.

O histórico da administração dos recursos hídricos australianos revela que os instrumentos mais comumente usados são os de comando e controle. Entre eles se destacam as licenças para extração e uso das águas, e os padrões de qualidade e de emissão, que fazem parte dos modelos de dispersão utilizados pelos Estados e Territórios para emissão das licenças. Estas, por sua vez, são outorgas de direito de uso das águas, as quais, na Austrália, são consideradas de domínio público.

A utilização dos instrumentos econômicos na gestão dos recursos hídricos é fato recente na história da administração das águas na Austrália. A South Australian Environment Protection Authority foi pioneira na utilização dos IEs, estabelecendo em 1990 um sistema de cobrança sobre a descarga de efluentes em águas costeiras e ambientes marinhos. Posteriormente, os Estados de Victoria e New South Wales introduziram um sistema de cobrança sobre o lançamento de efluentes em águas interiores, atrelado ao sistema de licença. Nos três casos mencionados a cobrança depende do tipo de atividade econômica praticada, dos poluentes encontrados no efluente, da quantidade lançada e da capacidade de assimilação do corpo de água. Entretanto, o valor cobrado segue a lógica da recuperação de custos administrativos. (JAMES, 1997)

Além da cobrança sobre lançamento de efluentes, existe em alguns estados o mercado de direitos de uso e poluição. Este é o caso da bacia do Murray-Darling e do vale do rio Hunter - situado no Estado de New South Wales, no qual as licenças são negociadas para controle da salinidade dos corpos de água. Outro exemplo, também localizado em New South Wales, é a área Hawkesbury-Nepean, onde o mercado visa ao controle de nutrientes. (JAMES, 1997) 
É interessante destacar que a política de recursos hídricos na Austrália possui a bacia hidrográfica como unidade administrativa. Entretanto, as escalas locais como vales, cidades e condados, participam de maneira ativa na gestão das águas, e muitas vezes são objetos de experiências-piloto.

Na Austrália a política de recursos hídricos é executada no âmbito dos Estados e Territórios. Portanto, o estudo da aplicação dos instrumentos econômicos na gestão das águas revela uma gama de experiências realizadas no país. Assim, para abordar a experiência australiana foram escolhidos três casos; a princípio é descrita a aplicação da cobrança pela captação de água em New South Wales, depois, são relatadas duas experiências de mercado de direitos de uso (New South Wales e Victoria).

\subsubsection{Formação do valor cobrado na Austrália}

\subsubsection{Cobrança sobre captação}

Em New South Wales, o sistema de cobrança sobre a captação é aplicado desde 1990. Nesse Estado, o serviço de oferta das águas é administrado pelo Department of Land and Water Conservation (DLWC), o qual controla o uso das águas dos grandes reservatórios, rios e aqüíferos, por meio do sistema de licenças para captação.

Entre 1990 e 1995, a cobrança era aplicada sobre usuários que utilizassem as águas regularizadas por reservatórios. Os valores cobrados, baseados no volume desviado ou outorgado, variava entre diferentes regiões. O objetivo do instrumento era cobrir parte dos custos de operação dos sistemas rurais de oferta da água. Assim, o governo arcava com 30\% destes custos e os usuários, por meio de cobrança anual, com os 70\% restantes. Os custos de capital, administrativos e de manutenção dos sistemas de armazenamento eram totalmente cobertos pelo governo federal. (ASAD et al., 1999)

Em 1996, os usuários das águas regularizadas passaram a arcar com parte dos custos administrativos do DLWC. Naquele ano foi também implementada a cobrança sobre usuários de águas não regularizadas e subterrâneas. Os valores cobrados eram (ASAD et al., 1999): 
- Um extra de AU\$ $1,35 / 10^{3} \mathrm{~m}^{3}$ ou US\$ $0,74 / 10^{3} \mathrm{~m}^{3}$ em valores atuais, para irrigação e serviços municipais de água cujas captações fossem feitas em rios regularizados (baseado no volume outorgado);

- Um valor total de AU\$ $10,00 / 10^{3} \mathrm{~m}^{3}$ ou US\$5,50/10 $\mathrm{m}^{3}$ em valores atuais, para indústrias cujas captações fossem feitas em rios regularizados (baseado no volume outorgado);

- Um valor anual fixado entre AU\$ 80,00 e AU\$ 265,00 ou US\$ 44,60 e US\$ 144,40 em valores atuais, para usuários que captassem em rios não regularizados;

- Um valor de AU $\$ 1,80 / 10^{3} \mathrm{~m}^{3}$ ou US\$ $0,98 / 10^{3} \mathrm{~m}^{3}$ em valores atuais, pago anualmente pelas Sydney e Hunter Water Corporations;

- Um valor anual fixo de AU\$ 75,00 ou AU\$ 100,00, isto é, US\$ 40,90 ou US\$ 54,50 em valores atuais, e mais uma taxa de AU\$ $0,40 / 10^{3} \mathrm{~m}^{3}$ ou US\$ 0,22, para usuários de águas subterrâneas baseada no volume outorgado;

- Eram isentos os usuários domésticos que captassem diretamente dos rios.

ASAD et al. (1999) relatam que por meio do Independent Pricing and Regulatory Tribunal (IPART) foram feitas, àquela época, várias críticas em relação à formação dos valores cobrados em New South Wales. Uma delas dizia respeito à existência de subsídios cruzados entre regiões, já que os valores cobrados eram baseados na média dos custos de oferta de água por região. Apesar dessa consideração, a formação dos valores não era transparente. Assim, o IPART argumentava que a cobrança deveria ser especificada para cada região, e que deveria ser baseada nos custos previstos pelo $D L W C$ para realização de suas funções.

Nesse contexto, ainda em 1996, o IPART sugeriu alguns princípios, os quais deveriam ser norteadores do sistema de cobrança (PIGRAM, 1998):

- A cobrança deveria ser baseada no modo mais eficiente de oferta de água;

- A gestão das águas deveria possuir estabilidade financeira;

- A cobrança deveria estimular usos da água e da infra-estrutura, os quais dessem os melhores resultados globais para a comunidade;

- Os custos de oferta de água deveriam ser pagos por quem os provocasse ou se beneficiasse dos serviços de oferta;

- A cobrança deveria promover o uso sustentável das águas e infra-estruturas. 
Baseado nestes princípios, o IPART formulou a proposta de revisão do sistema de cobrança sobre captação. Este sistema deveria incluir: (ASAD et al., 1999)

- Um componente para a recuperação dos custos de operação, manutenção, administração e capital dos serviços de oferta de água;

- Um componente para recuperação dos custos de gerenciamento e resolução dos conflitos de uso das águas;

- Uma cobrança separada sobre as licenças, para a recuperação dos custos de regulação do sistema de outorga de direitos de uso das águas;

- Um componente ambiental, para a recuperação dos custos de provimento de benefícios públicos difusos.

Nesse contexto, PIGRAM (1998) cita outras recomendações do IPART para a revisão do sistema de cobrança: remover os subsídios cruzados; melhorar a eficiência operacional dos serviços de oferta de água; implementar uma forma de cobrança para cobrir futuros gastos com renovação e reposição das infra-estruturas; e melhorar o monitoramento das captações em rios não regularizados e aqüíferos.

Como resultado desse processo iniciado pelo IPART, foi estabelecido em 1997 um sistema de cobrança dividido em duas partes. A primeira tratava de uma tarifa fixa baseada no volume de água outorgado, com a qual pretendia-se cobrir parte dos custos fixos; a segunda parte era uma cobrança variável, baseada no consumo de água, com a qual pretendia-se cobrir os custos variáveis de acordo com o volume de água ofertado. (ASAD et al., 1999; PIGRAM, 1998)

\subsubsection{Funcionamento do mercado de direitos de uso da água na Austrália}

Na Austrália, vários Estados têm adotado o mercado de direitos de uso da água como forma de alocação dos recursos hídricos. Embora a discussão a respeito deles tenha sido travada desde os anos oitenta, somente foram implantados, efetivamente, nos anos noventa.

Até recentemente o direito de uso das águas estava atrelado à posse de parcela específica de terra. Assim, as transferências de água eram realizadas apenas quando as terras eram negociadas e não havia restrições de uso por parte dos donos das 
terras. Hoje, as licenças são especificadas por volume e podem ser transferidas entre os diversos setores usuários. (PIGRAM, 1998; MALANO et al., 1999)

No Estado de New South Wales, por exemplo, a transferência de licenças de uso das águas foi inicialmente permitida em 1983. Naquele ano, foi estabelecido um sistema de transferências de água apenas entre irrigantes que captassem do mesmo curso de água regularizado. O objetivo dessa experiência era aliviar as conseqüências da seca. Entretanto, as transferências eram válidas somente por um ano; ao final do período de irrigação elas voltavam aos proprietários originais. Somente em 1989, foi introduzido o sistema de transferências permanentes. (PIGRAM, 1993)

PIGRAM (1993) comenta que a introdução das transferências permanentes dos direitos de uso das águas trouxe, a reboque, a necessidade de melhor definição desses direitos. Assim, os direitos passaram a ser expressos em megalitros por hectare, além disso, os gestores passaram a fornecer aos usuários indicativos sobre a probabilidade de atendimento dos respectivos direitos nos próximos períodos de irrigação.

É interessante destacar que os usuários da água do Estado de New South Wales, exigem avaliação da confiabilidade de seus direitos, ou seja, a percentagem de anos que determinado uso pode ser totalmente atendido. A argumentação dos irrigantes é baseada na percepção que, caso o direito esteja amarrado a um nível de confiança, é fácil e seguro adotar valores para ele. Assim, as licenças estariam atreladas a níveis diferentes de segurança de oferta de água. Aqueles irrigantes que necessitam vazões constantes e que cultivam produtos de alto risco e valor agregado, normalmente usam licenças com elevado grau de confiabilidade, pela qual pagam altos valores.

Normalmente, a exata especificação dos direitos de longo prazo de uso da água é dotada de incertezas relativas a fatores climáticos e expansão de usos entre setores usuários ou para outras funções, como o atendimento às necessidades ambientais. Portanto, a definição dos direitos de uso da água é tarefa complicada, na medida que é necessária alocação entre várias demandas. Na Austrália existe a preocupação em destinar água para atender as necessidades do meio ambiente. Nesse contexto, vários autores entendem que esse direito também deva fazer parte do sistema de mercado. Entretanto, em New South Wales o governo tem vetado possíveis transferências entre usos consuntivos e ambientais. (MALANO et al., 1999; PIGRAM, 1998) 
MALANO et al. (1999) relatam que em New South Wales a implementação das “vazões ecológicas” tem causado perdas para os irrigantes, por lhes ser negado acesso à quantidades de água que estavam acostumados a utilizar. Esse fato tem resultado em potenciais perdas de renda dos agricultores, que não são reparados por essas perdas. Neste caso, os irrigantes argumentam que pagam pela alocação de água para o meio ambiente, em benefício da comunidade.

É interessante destacar que, na Austrália, a introdução dos mercados de direitos das águas tem incentivado a implementação da cobrança sobre seus usos. Como o valor pago pelos direitos é maior que os da cobrança, isso tem levado os usuários a aceitarem progressivos aumentos no valor cobrado, cuja finalidade é cobrir os custos de oferta de água. (MALANO et al., 1999)

Outro exemplo do emprego do mercado das águas está no Estado de Victoria, onde historicamente são utilizados instrumentos de regulação direta. Nesse Estado, a alocação da água é feita em dois estágios: primeiramente os volumes são destinados a cada setor usuário que, no segundo estágio, aloca-os entre seus participantes. Cabe destacar que a água também é alocada para atender as necessidades do ambiente.

O Water Act de 1990 estabeleceu a possibilidade de transferências de direitos de uso da água permanentes ou temporários. Essas transferências podem apenas ser realizadas no mesmo sistema hídrico de oferta. No caso da irrigação, elas dependem da aprovação da Victorian Rural Water Corporation (RWC); apesar disso, não há restrições no volume a ser negociado. (JAMES, 1997)

O autor op. cit. comenta que a maioria das negociações efetivadas em Victoria são temporárias. Entre irrigantes, são raras as transações de licenças permanentes, entretanto, elas podem ser obtidas por meio de leilão realizado pela $R W C$. Nesse caso, os valores variam entre AU\$ 100,00 e AU\$ 775,00 por megalitro.

É interessante destacar que o emprego dos mercados de direitos de uso da água na Austrália é fato recente. Portanto, existem ainda diversas barreiras a ultrapassar, como a extinção dos subsídios cruzados entre regiões e a não restrição à transferência de direitos de uso entre Estados e setores usuários. 


\subsection{Caso do Chile*}

O sistema chileno de gerenciamento de recursos hídricos é dividido em setores. A irrigação é o setor mais organizado, por possuir uma grande tradição no país e ser o uso preponderante para a maioria dos corpos de água. Este aspecto tem sido indutor de conflitos de uso da água, agravado pelo fato de a quase totalidade dos rios do país encontrarem-se esgotados.

A primeira legislação chilena que sistematizou a gestão das águas foi o Código da Água de 1951. Este Código considerava a água um bem nacional de uso público como estabelecido pelo Código Civil - e permitia ao Estado outorgar concessões a particulares conforme prioridades de uso da água e - desde que o uso permanecesse o mesmo - eram permitidas as transferências de água.

Em 1967, a Lei da Reforma Agrária fez referência a um novo Código, que entrou em vigor a partir de 1969. Esse Código expandiu a intervenção do Estado no planejamento e administração dos recursos hídricos, inclusive tornou a água propriedade do Estado e proibiu a comercialização dos direitos de uso. Assim, foram revogados os direitos de uso concedidos, sem a legítima compensação aos proprietários.

A necessidade de expandir a atuação do Estado no controle da utilização dos recursos hídricos, fez com que o Código de 1969 criasse a Direção Geral de Águas (DGA). Essa entidade fixava padrões técnicos de uso racional da água, baseado no uso do solo e nas condições geográficas. Cabia a ela, também, realocar os direitos de uso e resolver possíveis conflitos.

Os resultados deste novo sistema não foram bons. A insegurança na alocação da água desencorajou os investimentos privados na gestão dos recursos hídricos e, em meados dos anos setenta, recomeçou o debate a respeito dos direitos privados de uso da água. Entretanto, somente em 1979 o governo voltou a reconhecer o mercado dos direitos de uso como instrumento capaz de alocar eficientemente a água.

Neste contexto, em 1981 foi aprovado o Código da Água - atual marco legal do sistema de gerenciamento das águas no Chile. Dentre suas características, destaca-se a utilização de mecanismos de mercado para alocação dos recursos hídricos que -

\footnotetext{
* Este item, salvo referência específica, é baseado no trabalho de BAUER (1997).
} 
principalmente na região centro-norte do Chile, possuem uma escassez severa. A utilização dos direitos de uso transacionáveis modificou drasticamente a tradição institucional de forte intervenção pública dos anos sessenta e setenta. Assim, o poder público abdicou dos exercícios de planejamento e desenvolvimento dos usos da água, e deixou que o livre mercado tomasse as decisões.

O Código de 1981 reintroduziu os direitos permanentes sobre a água, os quais são separados dos direitos sobre o solo e podem ser livremente comercializados para usos consuntivos e não consuntivos. Uma marcante diferença deste Código é o fato de o uso condicional adotado pelo Código de 1951 ter sido abolido, e os pedidos de outorgas simultâneos passarem a ser concedidos por meio de leilão. (SEROA DA MOTTA et al., 1996)

Acrescenta-se que nesse Código a água é considerada bem de domínio público, cujos direitos de uso são outorgados aos particulares. LANNA (1996) comenta que esse direito concede ao usuário a oportunidade de poder usar, gozar e dispor da água, como qualquer bem passível de apropriação privada e sob proteção jurídica similar.

A instituição responsável pela outorga dos direitos de uso é a Direção Geral de Águas (DGA). Caso exista disponibilidade de água, o direito de uso é concedido sem ônus para o usuário que o solicitou; porém, esgotada a capacidade de oferta do corpo de água, o usuário somente conseguirá adquirir cota por meio do sistema de mercado formado pelos proprietários dos direitos já outorgados.

Assim como os proprietários dos direitos não precisam pagar para adquirí-los, também não precisam gastar para manter os direitos ao longo do tempo. Ao contrário dos Códigos anteriores, os usuários não têm obrigação de utilizar suas cotas e não existe risco de cancelamento por falta de uso. Cabe destacar que foram reconhecidos todos os direitos outorgados ou adquiridos antes do Código de 1981.

Como já mencionado, os proprietários dos direitos de uso da água possuem liberdade para transacioná-los. Este aspecto contribui para que localização e tipos de uso periodicamente variem no tempo e no espaço. Cabe ressaltar que essas mudanças não precisam ser aprovadas pela DGA (exceto se ocorrer desvio do curso natural da água). Além disso, os candidatos a adquirir novos direitos de uso não precisam especificar ou justificar suas intenções. 
As atuais funções da DGA são restritas a aspectos técnicos e administrativos, pois a maior parte das decisões relativas à gestão das águas, é tomada pelos agentes privados, principalmente por meio de Juntas de Vigilância, Associações de Usuários de Canais e Comunidades de Água. Até mesmo o poder de intermediação que a DGA detinha, em caso de conflitos de uso, passou a um tribunal ordinário.

Apesar disso, a DGA mantêm uma gama de tarefas, dentre as quais citam-se: reunião e manutenção de base de dados hidrológicos; fiscalização de grandes obras como barragens e canais; regulamentação do funcionamento das associações privadas de usuários da água; manutenção do cadastro de outorgas e de associações de usuários. Cabe destacar que a DGA também pode preparar estudos, planos e recomendações políticas; estes mecanismos, no entanto, somente possuem força de regulação caso sejam aprovados por outras entidades governamentais. A FIGURA 1 ilustra o sistema chileno de gestão das águas.

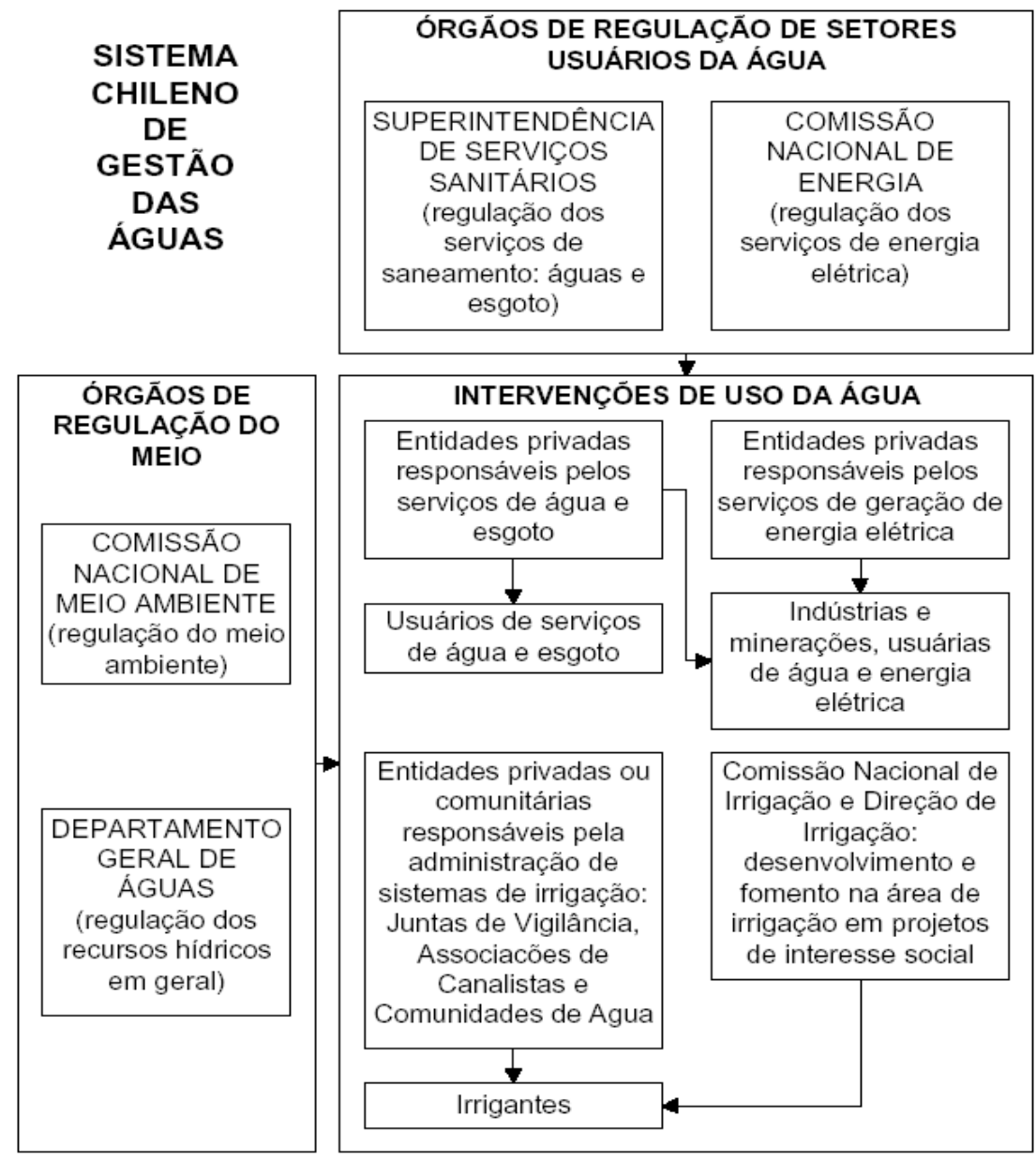

FIGURA 1 - Organograma do sistema chileno de gestão das águas.

Fonte: LANNA (1996). 
Em 1992 foi remetida ao Congresso Nacional uma proposta de reformulação do Código da Água de 1981. As principais críticas ao Código dizem respeito à não obrigatoriedade de uso dos direitos - aspecto que oferece ao proprietário a alternativa de especular. A DGA argumenta que isto é socialmente injusto e economicamente indesejável, por permitir que agentes privados tirem proveito de um recurso público, sem contrapartida de ganho social ou econômico.

Neste contexto, a DGA propôs que os direitos que não fossem utilizados por um período de 5 anos, poderiam ser cancelados sem compensação ao proprietário, e então, repassados para outros usuários com necessidade premente. O argumento legal utilizado pela DGA mencionava que: como a água era de domínio público, o Estado poderia estabelecer regras de uso de direitos sem violar os direitos outorgados.

Entretanto, a proposta encaminhada pela DGA sofreu oposição da iniciativa privada, principalmente dos agricultores. O argumento utilizado era que o Estado não poderia impor novas restrições sobre um direito adquirido, sem justa compensação. Os oposicionistas argumentavam também que as falhas do Código de 1981 deveriam ser corrigidas por mecanismos compatíveis com a lógica de mercado, e não por meio de imposições administrativas. Assim, em 1996 foi enviada ao Congresso proposta de aplicação de taxa anual por não uso dos direitos, a qual variaria de acordo com as regiões, usos consuntivos e não consuntivos, e aumentaria ao longo do tempo.

As propostas de reformulação do Código da Água ainda tramitam no Congresso Nacional do Chile. Em dezembro de 1999 foi levada ao conhecimento do Presidente da República, a proposta de Política Nacional de Recursos Hídricos formulada pela DGA. Nela é ratificada a necessidade de reformulações propostas para o Código da Água, com intuito de corrigir as distorções do sistema de outorga e mercado dos direitos de uso. A Política aborda a importância de gestão mais integrada, descentralizada, que conte com a participação do setor público, privado e sociedade civil. Nela são previstos os Planos Diretores para Gestão Integrada dos Recursos Hídricos, reconhecida a importância da gestão por bacias hidrográficas, inclusive com a proposta de estabelecimento das Corporações Administradoras de Bacia. (DIRECCION GENERAL DE AGUAS, 1999)

Em relação aos direitos de uso, a Política ratifica que a aprovação das propostas de mudança do Código de 1981 é passo essencial para uso sustentável da água. 
Além da proposta da taxação pelo não uso dos direitos outorgados, são propostas outras modificações: obrigar os usuários a justificar a quantidade de água solicitada, de maneira que exista concordância entre quantidade pedida e finalidade pretendida; autorizar o Estado limitar ou recusar novos pedidos de outorga; garantir que sejam respeitadas as vazões ecológicas quando da aprovação de novos direitos.

\subsubsection{Funcionamento do mercado de direitos de uso da água no Chile}

Os direitos de uso da água no Chile são divididos em categorias. Distinguem-se em direitos consuntivos e não consuntivos; permanentes e eventuais. Um direito consuntivo permite a retirada de água para consumo, sem necessidade de devolução para o corpo de água, como no caso do direito não-consuntivo. O direito permanente possibilita a utilização da água a qualquer momento, enquanto o direito eventual somente faculta o uso se os usos permanentes tenham sido atendidos. Cabe destacar que esses direitos são assegurados por registro em cartório.

As associações de usuários são entidades responsáveis pelo monitoramento, distribuição e aplicação dos direitos de propriedade da água. Essas funções podem ser exercidas em nível de bacia hidrográfica e canais de adução. As associações são proprietárias que operam as infraestruturas hidráulicas de suprimento e cobram tarifas por esse serviço. LANNA (1996)

Em certas regiões chilenas, o mercado das águas envolve pequena porcentagem dos usuários e, por conseqüência, ocorrem poucas transferências de usos dos recursos hídricos. SEROA DA MOTTA et al. (1996) citam como exemplo o ano de 1992, no qual os registros de transações revelam maior intensidade de comercialização na área de influência da capital Santiago, por motivos de escassez. Naquele ano, apenas 3\% do volume total de água foi comercializado naquela área e 94\% do volume comercializado deveu-se a transações entre fazendeiros. A comercialização entre os usuários urbanos e fazendeiros não excedeu 3\% do volume total transacionado.

SERAGELDIN (1995) comenta que muitas transações entre fazendeiros podem ser consideradas uma espécie de "mercado spot”, no qual o proprietário do direito vende parte dele por um período curto de tempo, muitas vezes sem cumprir o procedimento legal de registro da transação. Normalmente, esse tipo de transação, 
entre proprietários de terras vizinhos, já eram feitas mesmo antes do Código de 1981. Trata-se, portanto, de transação temporária (aluguel do direito de uso).

O mercado de direitos de uso da água tem sido mais efetivo na região centronorte do Chile onde predomina a produção de frutos de alto valor agregado. Essa região possui clima quente e seco, que favorece esse tipo de cultura. O número de transações efetuadas entre os detentores dos direitos é maior nessa região, devido à maior dinâmica da agricultura e ao elevado valor da água.

Na bacia do rio Limarí, norte de Santiago, as transações têm contribuído para eficiência econômica na alocação da água. Nessa bacia, existe três reservatórios e Associações de Usuários de Canais bem organizadas; estes aspectos colaboram para eficiência do mercado das águas, principalmente, devido à garantia atribuída aos reservatórios na disponibilidade de água. MENDES \& SEROA DA MOTTA (1997) afirmam que nessa bacia o aluguel de uma cota de direito de uso (1 litro/segundo), durante três meses, alcança valores entre US\$ 90 a 120 nos períodos de estiagem.

Apesar do exemplo citado acima, de maneira geral, é limitado o sistema de mercado das águas chileno. Com a maioria das transações restrita ao setor agrário. Transferências entre setores usuários distintos ocorrem, basicamente, de duas formas: quando as cidades se expandem em direção a zonas rurais e quando as mineradoras, por aumentarem a produção, necessitam mais água - normalmente adquirida do setor agrícola.

As limitações do sistema chileno são causadas por diversos fatores. Entre eles podem ser citados: aspectos geográficos e de infra-estrutura; legais e administrativos; culturais e psicológicos; e de formação dos preços da água. Entretanto, muitos desses obstáculos podem ser superados por meio de mudanças na legislação e da crescente necessidade de se administrar a escassez.

BAUER (1997) descreve, de forma detalhada, como esses aspectos interferem no mercado de direitos de uso da água no Chile. Os obstáculos relativos aos aspectos legais e administrativos provêm da incerteza na origem dos direitos de uso, pois boa parte não é registrada oficialmente, fato esse que dificulta transações e investimentos. Algumas ações têm sido feitas para mudar esse quadro, cita-se como exemplo que desde 1990 a DGA tem incentivado as regularizações dos direitos, como parte do programa de formação das organizações de usuários. 
Outro obstáculo administrativo diz respeito à resolução de conflitos de uso. Conforme dito anteriormente, a partir do Código de 1981, a DGA interfere apenas em transações que venham modificar o curso natural do corpo d’água; caso contrário essa entidade não possui autoridade para intervir e contornar um possível conflito. Portanto, os proprietários afetados por negociações de terceiros podem protestar somente junto às Associações de Usuários de Canais ou aos tribunais civis, nos quais os procedimentos tendem a ser lentos, devido ao desconhecimento dos aspectos técnicos dos direitos de uso e, também à lentidão do sistema judiciário.

Em relação à formação dos preços no mercado de direitos de uso, presumia-se que - com o mercado da água, os preços cresceriam conduzidos pelo aumento das demandas urbanas e industriais, aspecto característico de países em desenvolvimento. Para suprir essas novas demandas, a água seria transferida do setor agrícola (maior usuário, com 84,5\% do uso consuntivo) para os demais; desta maneira os irrigantes seriam forçados a usar a água eficientemente e a optar por culturas de valor agregado elevado.

Entretanto, esse cenário não foi verificado na prática: a formação dos preços se mantém incerta e não representativa do real valor da água. Ainda existe forte resistência dos agricultores na venda de seus direitos. No vale central, por exemplo, o valor das terras irrigadas é de 3 a 10 vezes maior que o valor das terras não irrigadas, portanto, em teoria, o preço dos direitos deveria ser equivalente a essa diferença. Porém, raramente os compradores oferecem tal montante sem solicitar inclusão da terra na negociação; e os vendedores, por sua vez, também não têm interesse em ficar com as terras sem poder desfrutar de água. Este fator explica o motivo de a maioria das transações ainda permanecem vinculadas à posse da terra.

Muitos proprietários de direitos de uso se recusam a negociá-los com o intuito de especular. Como não são obrigados a utilizar os direitos que possuem, estes são resguardados para negociação até que os preços sejam satisfatórios. A especulação é agravada pela falta de imposições administrativas que obriguem o proprietário a usar seus direitos.

Existem algumas justificativas que explicam porque é pequeno o número de transações no mercado de água chileno. Em primeiro lugar, a água economizada no setor agrícola - por meio da melhoria na eficiência da irrigação - que, no Chile, fica 
em torno de 25\%, é usada pelos próprios fazendeiros para aumento da área irrigada. Em segundo lugar, existe a possibilidade de uso da água subterrânea. Apesar dos gastos iniciais e com energia para bombeamento, estas águas possuem a vantagem de serem abundantes e pouco exploradas no Chile. Em terceiro, há a alternativa de se obter, diretamente da DGA, direitos de uso eventuais, mesmo que estes possam ser usados apenas quando todos os usos permanentes forem atendidos, há a possibilidade de serem utilizados em épocas de chuva, quando as vazões são altas e é baixa demanda para irrigação. Assim, os proprietários desse tipo de direito podem estocar água e utilizá-la durante períodos de seca.

De maneira geral, os baixos valores dos recursos hídricos não têm incentivado o uso racional da água. São poucos os exemplos de investimentos privados em tecnologias de irrigação com o propósito de economizar água para comercializá-la no mercado de direitos de uso.

Na maior parte da região centro-sul, onde predomina os cultivos de grãos, ervilha, feijão, beterraba, etc., a eficiência na irrigação permanece com valores entre 20 e 30\% e a irrigação por inundação ainda é prática corriqueira. Por outro lado, na região centro-norte, próxima a Santiago, na qual predomina a fruticultura, alguns agricultores têm investido em sistemas de irrigação por gotejamento, embora eles se sintam mais motivados a investir devido a aspectos agronômicos e econômicos, que os relativos à escassez de água.

De maneira geral, no Chile, os resultados esperados do funcionamento do mercado de direitos de uso da água, ficaram aquém das expectativas iniciais. Existem diversas razões de ordem institucional, legal, econômica e até cultural que tentam explicar essas distorções. Entretanto, cabe destacar que a aplicação desse tipo de instrumento econômico de gestão, geralmente é acompanhada de elevados custos de transação, os quais muitas vezes inviabilizam seu uso.

No caso chileno, o funcionamento do mercado ajudou a consolidar a autonomia das associações de usuários da água, além de encorajar alguns investimentos em agricultura irrigada voltada para exportação (fruticultura). A tendência, a partir das reformulações no Código da Água e da aprovação da Política Nacional dos Recursos Hídricos, é que o mercado de direitos se estabeleça como instrumento de gestão. Ao Estado, caberá ser o balizador de gestão integrada, descentralizada e participativa. 


\subsection{Caso do México}

No México a administração dos recursos hídricos é realizada pela Secretaria de Meio Ambiente e Recursos Naturais (SEMARNAT). A entidade responsável pela execução da política das águas é a Comissão Nacional da Água (CNA) - unidade administrativa ligada a SEMARNAT, mas com atuação independente. Criada em 1989, a CNA exercia funções de caráter normativo, financeiro, de construção, operação e promoção do desenvolvimento hidráulico. Hoje, as funções dessa agência estão voltadas à preservação da qualidade da água e à promoção do uso sustentável dos recursos hídricos. Neste contexto, à CNA cabe administrar as águas nacionais, fiscalizar o cumprimento da Lei de Águas Nacionais, além de promover, executar e administrar a infraestrutura hidráulica de domínio federal.

Atualmente, o marco legal da administração das águas no México é a Lei de Águas Nacionais, promulgada em dezembro de 1992, em substituição à Lei Federal de Águas de 1972. A lei de 1992 regulamentou o art. 27º da Constituição Mexicana e, a reboque, trouxe os objetivos de regular a exploração, uso ou aproveitamento das águas nacionais, sua distribuição e controle, além de sua preservação em quantidade e qualidade em busca do desenvolvimento integral sustentável. (Art. $1^{0}$ )

A lei das águas mexicana estabelece a bacia hidrográfica, em conjunto com os aqüíferos, como unidade de gestão dos recursos hídricos e, ao Poder Executivo Federal, atribui a tarefa de administrar as águas nacionais, seja de maneira direta ou por meio da CNA. Como forma de garantir a participação das escalas menores de poder, como os Estados e Municípios, cabe ao Executivo promover a coordenação de ações entre essas diferentes instâncias. Mas a tarefa de assegurar a participação dos usuários na administração das águas é papel da CNA, por meio da instituição dos Conselhos de Bacia, que servem como fóruns de coordenação e acordo entre as instâncias federais, estaduais e municipais, os usuários e a sociedade civil. Compõem os Conselhos de Bacia: um presidente com direito a voto de Minerva, representado pelo Diretor Geral da CNA; um secretário técnico sem direito a voto, nomeado pelo Diretor Geral da CNA; um representante dos usuários de cada tipo de uso existente na bacia, com direito a voto e em quantidade pelo menos paritária em relação aos demais integrantes do conselho, os quais não são mencionados na legislação. 
Uma análise da Lei de Águas Nacionais revela quais são os instrumentos em gestão de recursos hídricos utilizados no México. Diferentemente da legislação brasileira de gestão das águas, a lei mexicana não reserva um capítulo específico para enumeração e descrição dos instrumentos adotados; eles são apresentados em diferentes Títulos da lei.

O Título Terceiro, chamado Programação Hidráulica, prevê a aprovação do programa nacional hidráulico - uma espécie de plano nacional das águas. Ademais, esse Título abrange uma gama de atividades, entre as quais: formulação e integração de subprogramas específicos, regionais, de bacias, estaduais e setoriais; formulação e atualização do inventário das águas nacionais, de seus usos e da infraestrutura utilizada para seu aproveitamento e controle; integração e atualização dos catálogos de projetos para aproveitamento das águas e para preservação e controle de sua qualidade; classificação dos corpos de água em classes de uso; formulação de estratégias e políticas para regulação do uso da água; e promoção de mecanismos de consulta e participação para execução dos programas. É interessante destacar que, neste Título da lei mexicana, estão previstos três instrumentos de gestão. Comparado à política das águas brasileira, os instrumentos seriam: Planos de Recursos Hídricos, enquadramento dos corpos de água em classes de uso e parte do Sistema de Informações sobre Recursos Hídricos.

Essa característica da legislação mexicana se repete ao longo do demais Títulos da Lei de Águas Nacionais. O Título Quarto - dos direitos de uso ou aproveitamento de águas nacionais - prevê a outorga de direito de exploração, uso ou aproveitamento das águas nacionais, cuja obrigatoriedade se estende a pessoas físicas e jurídicas, bem como a entidades da administração pública federal, estadual e municipal. As outorgas são fornecidas pela CNA e registradas no Registro Público de Direitos de Águas. É interessante destacar que no Capítulo V deste mesmo Título está prevista a possibilidade de transmissão dos títulos de outorga de uso da água. Esse ponto da lei constituiu o primeiro passo para o estabelecimento dos mercados de direitos de uso das águas. Entretanto, o mercado das águas ainda não é instrumento formalmente constituído no México. São limitados a usuários inseridos em um mesmo distrito de irrigação; assim, as transferências entre distritos e outros setores usuários são restritas e carecem de procedimentos mais eficientes. (EASTER \& HEARNE, 1995) 
O Título Quinto discorre sobre as áreas de regulação, de proibição ou reserva de extração e utilização das águas nacionais. Nessas zonas, tendo em vista o interesse público, ficam estabelecidas regras de uso da água. Assim, o Executivo Federal pode estabelecer essas áreas para prevenir ou remediar a superexploração dos aqüíferos; proteger ou restaurar um ecossistema; preservar fontes de água potável ou protegêlas da poluição; preservar ou controlar a qualidade da água; e, ainda, motivado pela escassez ou secas extraordinárias.

No Título Sétimo - relativo à prevenção e controle da contaminação das águas, alguns instrumentos estão implícitos em seus artigos. É o caso do monitoramento do padrão de emissão das cargas efluentes e da qualidade das águas para abastecimento urbano. Finalmente, no Título Oitavo - referente aos investimentos em infraestrutura hidráulica - está prevista a cobrança sobre exploração, uso ou aproveitamento de águas nacionais, bem como, sobre exploração, uso ou aproveitamento de bens de domínio público da nação, como corpos receptores de descargas de águas residuárias, de acordo com o estabelecido na Lei Federal de Direitos. Portanto, a cobrança é o único instrumento econômico de gestão, formalmente previsto na Lei de Águas Nacionais.

Vale ressaltar que embora a Lei de Águas Nacionais faça referência à cobrança, nem seu texto, nem sua regulamentação, trazem qualquer especificidade em relação à aplicação desse instrumento econômico, que é regulado por outra legislação - a Lei Federal de Direitos. Essa lei estabelece, desde 1981, o pagamento pelo direito de uso da água como recurso natural e, desde 1991, a cobrança sobre lançamento de efluentes em corpos de água de domínio público.

Deste modo, data de 1991 o uso dos instrumentos econômicos no controle da poluição hídrica no México - com a reformulação da Lei Federal de Direitos de 1981. Essa reforma estabeleceu a cobrança pelo direito de lançar efluentes em corpos de água, no solo ou infiltrá-los em terreno. Para tanto, em 1991, foi adicionado à Lei Federal de Direitos o Capítulo XIV, dedicado ao "direito por uso ou aproveitamento de bens de domínio público da nação como corpos receptores de descargas de águas residuárias”. (CEPAL, 2000)

Naquela época, coube à Comissão Nacional da Água (CNA) a responsabilidade pela aplicação do sistema de cobrança. De 1991 a 1995, o sistema funcionava como 
uma multa por não atendimento, uma vez que a cobrança era efetuada caso os limites estabelecidos como padrão de emissão não fossem respeitados, portanto, não havia incentivo à redução das concentrações de poluentes para valores inferiores a esses limites. Os parâmetros de poluição utilizados eram Demanda Química de Oxigênio (DQO) e Sólidos Suspensos Totais (SST).

Na aplicação da cobrança, os corpos hídricos eram divididos em quatro zonas de disposição, de acordo com as quais variava o valor unitário da cobrança por tonelada de carga poluente. Portanto, a cobrança era efetuada sobre o produto entre $o$ volume mensal lançado, zona de disposição e a diferença entre a poluição produzida e a permitida. Para volumes menores que $3.000 \mathrm{~m}^{3}$ por mês, a cobrança se dava sobre o volume emitido multiplicado por uma taxa unitária fixa.

Este sistema de cobrança perdurou até 1995 quando se deu sua revisão. A partir de então a Lei Federal de Direitos tem sofrido sucessivas mudanças. A primeira, derivada da revisão de 1995, permaneceu somente ao longo de 1996. Nesse ano, o sistema de cobrança passou a atuar como uma taxa sobre o lançamento de efluentes com qualquer nível de poluição. Ademais, houve mudanças referentes à localização das descargas, pois as zonas de disposição, que eram diferenciadas de acordo com a disponibilidade hídrica, foram abandonadas e substituídas pela especificidade de cada corpo receptor, os quais passaram a ser classificados em conformidade com sua capacidade de assimilação - baseada nos níveis de tratamento requeridos para manter a quantidade de poluentes sob controle. (SEROA DA MOTTA, 1998)

Assim, os corpos de água mexicanos foram divididos em três categorias: os que requeriam tratamento primário; aqueles que requeriam tratamento secundário; e os que requeriam tratamento mais sofisticado. Os parâmetros de poluição continuaram os mesmos (DQO e SST), e a cobrança variava de acordo com o tipo de corpo de água e com a concentração do poluente. Para tanto, existiam quatro classes: acima de 150 mg/L; entre 150 e 75 mg/L; entre 75 e 30 mg/L e menos de 30 mg/L. Desta maneira, os valores unitários cobrados variavam de acordo com os custos de controle; quanto melhor o nível de tratamento requerido pelo corpo de água e maior fosse a concentração de carga poluente - mais onerosa era a cobrança.

Desta forma, o sistema pretendia induzir maior controle de descargas poluentes, inclusive em concentrações abaixo do padrão de emissão. Outro aspecto interessante 
é que, independente dos valores unitários cobrados, o método de cobrança aplicado levava em conta a escassez relativa ao reconhecer, por meio das três categorias em que os corpos hídricos estavam classificados, as distintas capacidades de assimilação. Assim, quanto mais saturado fosse o corpo de água, maior seria o nível de controle exigido e, portanto, mais elevado seria o valor cobrado.

Segundo SEROA DA MOTTA (1998), as mudanças no sistema objetivavam a indução dos usuários em ações de controle, com o intuito de atingir um certo padrão ambiental. Para o autor, desta maneira, a cobrança seguiria os conceitos da análise custo-eficiência, embora, mantivesse também o objetivo de geração de receita.

O sistema adotado em 1996 previa algumas isenções a determinados usuários. Era o caso, por exemplo, das localidades com população inferior a 2.500 habitantes e os serviços autônomos de água que porventura servissem a essas comunidades. Além disso, aqueles que lançassem volumes inferiores a $3.000 \mathrm{~m}^{3}$ por mês ainda tinham a opção de pagar uma taxa fixa por metro cúbico - de acordo com o corpo receptor.

Em 1997 entrou em vigor novo sistema de cobrança, que permanece até hoje sem mudanças significativas. É interessante destacar que o atual sistema prevê a cobrança sobre lançamentos que estejam acima dos limites do padrão de emissão, ou seja, optou-se novamente por um método de cobrança mais parecido à multa por não atendimento. Vale ressaltar, no entanto, que com limites estabelecidos mais rigorosos e os parâmetros de poluição usados na cobrança - antes somente DQO e os SST passaram a 16 (dezesseis) parâmetros.

Segundo ASAD et al. (1999), o novo sistema de cobrança usado desde 1997, mais flexível e compreensível, requer, entretanto, um aparato em infra-estrutura de fiscalização, monitoramento e controle das descargas, em níveis que a CNA ainda não possui. Essa mesma opinião é compartilha por SEROA DA MOTTA (1998), para quem, a implantação da cobrança no México possui falhas, entre as principais estão as dificuldades no monitoramento e a oposição dos poluidores.

É interessante ressaltar que, ao México, ainda faltam capacidade institucional e implementação de outros instrumentos, que sirvam de apoio à própria cobrança e componham um sistema de gestão. Neste sentido, alguns esforços estão sendo feitos no México, como incentivo à participação da sociedade, geração de informações e organização institucional. Mesmo assim, ainda persistem algumas barreiras políticas. 
Neste contexto, TORTAJADA (1999) comenta que é evidente e considerável o progresso do México na formulação dos regimes legal e de regulamentação da gestão das águas; entretanto, a implementação deles ainda é pobre e dotada de contradições.

\subsubsection{Formação do valor cobrado no México}

Esta seção é baseada na última atualização da Lei Federal de Direitos de janeiro de 2002. Em seu Título II - relativo aos direitos por uso ou aproveitamento de bens de domínio público - o Capítulo VIII é reservado ao direito sobre a água, e o Capítulo XIV ao direito sobre o uso ou aproveitamento de bens de domínio público da nação, como corpos receptores de descargas de águas residuárias.

\subsubsection{Cobrança sobre captação}

A Lei Federal de Direitos obriga ao pagamento do direito sobre a água, pessoas físicas e jurídicas que usem, explorem ou aproveitem as águas nacionais. A cobrança, efetuada sobre captação de águas superficiais e subterrâneas, independe da posse dos títulos de outorga de direitos de uso. O valor cobrado é diferenciado de acordo com 9 zonas de disponibilidade de água - válidas para ambas as fontes. Na TABELA 8 são apresentados os valores cobrados de acordo com cada zona.

Para empresas públicas e privadas de abastecimento urbano de água, os valores cobrados são diferentes e incidem sobre o volume fornecido à população. Neste caso, a arrecadação derivada dos municípios é destinada à CNA, que a utiliza em obras de infraestrutura hidráulica. Vale salientar que essa cobrança incide sobre a água tratada fornecida - medida na saída da concessionária de abastecimento, embora seja devida à captação de água bruta. Os usos da água na geração hidrelétrica, aqüicultura e em balneários e centros recreativos - exceto os de acesso exclusivo ou privado, hotéis e campos de golfe - são outros usos que pagam valores de cobrança diferenciados. As TABELAS 9, 10, 11 e 12 apresentam os respectivos valores cobrados, retirados da Lei Federal de Direitos. Considera-se a cotação do Dólar no dia 15/07/2002. 
TABELA 8 - Valores cobrados de acordo com zonas de disponibilidade de água.

\begin{tabular}{c|c|c}
\hline \multirow{2}{*}{ Zonas } & \multicolumn{2}{|c}{ Valor Cobrado $\left(\$ / \mathrm{m}^{3}\right)$} \\
\cline { 2 - 3 } & Peso Mexicano & Dólar \\
\hline 1 & 13,3885 & 1,3551 \\
2 & 10,7105 & 1,0841 \\
3 & 8,9253 & 0,9034 \\
4 & 7,3636 & 0,7453 \\
5 & 5,8014 & 0,5872 \\
6 & 5,2431 & 0,5307 \\
7 & 3,9466 & 0,3994 \\
8 & 1,4023 & 0,1419 \\
9 & 1,0509 & 0,1064 \\
\hline
\end{tabular}

TABELA 9 - Valores cobrados sobre captação de água para abastecimento urbano.

\begin{tabular}{c|c|c}
\hline \multirow{2}{*}{ Zonas } & \multicolumn{2}{|c}{ Valor Cobrado $\left(\$ / 1000 \mathrm{~m}^{3}\right)$} \\
\cline { 2 - 3 } & Peso Mexicano & Dólar \\
\hline 1 a 6 & 265,24 & 26,85 \\
7 & 123,52 & 12,50 \\
8 & 61,69 & 6,24 \\
9 & 30,73 & 3,11 \\
\hline
\end{tabular}

TABELA 10 - Valor cobrado sobre uso da água para geração de energia elétrica.

\begin{tabular}{c|c|c}
\multirow{2}{*}{ Zonas } & \multicolumn{2}{|c}{ Valor Cobrado $\left(\$ / 1000 \mathrm{~m}^{3}\right)$} \\
\cline { 2 - 3 } & Peso Mexicano & Dólar \\
\hline Todas & 2,8145 & 0,2849 \\
\hline
\end{tabular}

TABELA 11 - Valores cobrados sobre captação de água para aqüicultura.

\begin{tabular}{c|c|c}
\hline \multirow{2}{*}{ Zonas } & \multicolumn{2}{|c}{ Valor Cobrado $\left(\$ / 1000 \mathrm{~m}^{3}\right)$} \\
\cline { 2 - 3 } & Peso Mexicano & Dólar \\
\hline 1 a 6 & 2,1863 & 0,2213 \\
7 & 1,0768 & 0,1090 \\
8 & 0,5065 & 0,0513 \\
9 & 0,2406 & 0,0244 \\
\hline
\end{tabular}


TABELA 12 - Valores cobrados sobre uso da água em balneários e centros recreativos.

\begin{tabular}{c|c|c}
\hline \multirow{2}{*}{ Zonas } & \multicolumn{2}{|c}{ Valor Cobrado $\left(\$ / 1000 \mathrm{~m}^{3}\right)$} \\
\cline { 2 - 3 } & Peso Mexicano & Dólar \\
\hline 1 a 6 & 7,6156 & 0,7708 \\
7 & 3,7521 & 0,3798 \\
8 & 1,7665 & 0,2150 \\
9 & 0,84 & 0,0850 \\
\hline
\end{tabular}

Alguns usuários ou usos são isentos da cobrança; agricultores e pecuaristas que utilizem água para suas necessidades domésticas sem desviá-las do curso natural; usuários que utilizem águas residuárias - deixando de usar água bruta na mesma proporção ou provenientes de coletores de esgotos urbanos ou industriais; águas que brotem ou apareçam nos trabalhos de mineração ou que provenham da drenagem das minas, salvo se as mesmas forem utilizadas por indústrias ou serviços; usos para agropecuária, incluindo os distritos e unidades de irrigação; institutos de educação exceto usos para conservação ou manutenção de áreas ornamentais ou esportivas.

Também estão isentas da cobrança as águas que retornem à fonte original ou a outra localidade previamente autorizada pela CNA. Para tanto, os usuários devem ter um certificado de qualidade da água, o qual comprove que a mesma está de acordo com os limites de qualidade estabelecidos, levando-se em conta o destino posterior da água. Os parâmetros de qualidade se dividem entre inorgânicos, orgânicos, físicos e microbiológicos, e diferenciam-se quatro possíveis destinos dados à água: uso para abastecimento urbano, irrigação, proteção da vida aquática de águas doces e proteção da vida aquática de águas costeiras e estuários. Vale lembrar que essas considerações não são validadas para uso da água na geração hidrelétrica.

Existem ainda outros casos nos quais não incide a cobrança sobre a exploração, uso ou aproveitamento da água. Podem ser citados; uso de águas interiores salobras desde que certificada pela CNA a presença de mais de $2.500 \mathrm{mg} / \mathrm{L}$ de sólidos totais dissolvidos; populações rurais até 2.500 habitantes e serviços de abastecimento correlatos; entidades públicas ou privadas sem fins lucrativos que prestem serviços 
de assistência médica, serviço social ou de educação escolar gratuita em benefício de populações rurais até 2.500 habitantes.

Os usuários que efetivamente cumprem com o pagamento da cobrança podem subtrair do total, os custos de obtenção e instalação dos aparelhos de medição de vazão. Cabe observar que essa medição possui importância relevante neste Capítulo da Lei Federal de Direitos. É previsto, por exemplo, que os aparelhos de medição devem possuir um selo oficial da CNA e que qualquer problema com o medidor deve ser comunicado à Comissão no prazo de 10 dias.

É preciso destacar que a Lei Federal de Direitos, por meio da qual é regulado o sistema de cobrança sobre captação de água no México, não faz referência ao modo como as zonas de disponibilidade foram diferenciadas, embora, a princípio, pareça uma distinção em que são considerados somente aspectos relativos à disponibilidade quantitativa. Entretanto, apesar de atender exclusivamente a esse aspecto, a aplicação do sistema de cobrança é coerente com o preceito da escassez relativa, pois onera mais fortemente àqueles usuários situados em regiões de grande concentração urbana e industrial, portanto, mais saturadas.

\subsubsection{Cobrança sobre lançamento de efluentes}

O sistema de cobrança sobre lançamento de efluentes é regulado por meio do Capítulo XIV do Título II da Lei Federal de Direitos. Na legislação é estabelecida a obrigação de pagamento pelas águas residuárias lançadas de maneira permanente, intermitente ou fortuita, em corpos de água, no solo ou infiltradas em terreno. Assim, as pessoas físicas e jurídicas estão sujeitas à cobrança sobre o uso dos corpos de água nacionais nos quais lançam seus efluentes.

A cobrança estabelecida depende do tipo de corpo receptor, do volume lançado e dos poluentes encontrados no efluente. Estão sujeitos ao pagamento os usuários que lancem acima dos limites estabelecidos como padrão de emissão e, nestes casos, somente é cobrado o excedente de poluição. É, portanto, essa característica que torna o sistema mexicano de cobrança em multa por não atendimento, um instrumento de comando e controle. Vale destacar que, ao longo da década de 90, o desenvolvimento 
do sistema estabeleceu a cobrança como instrumento econômico de gestão somente em 1996, em 1997 retrocedeu ao sistema inicial de 1991 - porém mais elaborado.

De qualquer maneira, apesar desse trabalho não considerar as multas por não atendimento um tipo de instrumento econômico, é interessante apresentar e analisar a maneira pela qual a cobrança está estabelecida na legislação, principalmente porque a Lei Federal de Direitos passa por constantes reformulações, o que torna mais fácil ajustar o atual sistema em verdadeiro instrumento econômico de gestão.

No atual sistema, os corpos de água são classificados em 3 tipos. Os de tipo A compreendem rios usados para irrigação e aqüíferos, águas costeiras com exploração pesqueira, navegação e outros usos, e solos utilizados na irrigação; os de tipo B são representados pelos rios usados para abastecimento urbano e aqüíferos, reservatórios naturais e artificiais utilizados para irrigação, águas costeiras usadas para recreação, estuários e várzeas ou pântanos; os de tipo C são rios utilizados para proteção da vida aquática, reservatórios naturais e artificiais utilizados para abastecimento urbano e aqüíferos.

Conforme a localização da descarga existe um padrão de emissão específico, ou seja, em um mesmo tipo (A, B ou C) pode haver limites diferenciados, dependendo da natureza do corpo receptor. Os parâmetros utilizados são: Óleos e Graxas; Sólidos Suspensos Totais (SST); Demanda Bioquímica de Oxigênio (DBO); Nitrogênio (N); Fósforo (P); Arsênico ( $\left.\mathrm{As}_{2} \mathrm{O}_{3}\right)$; Cádmio (Cd); Cobre $(\mathrm{Cu})$; Cromo (Cr); Mercúrio (Hg); Níquel (Ni); Chumbo (Pb); Zinco (Zn); Cianetos ( $\left.\mathrm{CN}^{-}\right)$; Coliformes Fecais; e pH. No caso dos dois últimos parâmetros, os limites estabelecidos como padrão de emissão são os mesmos para todos os corpos de água. São eles: 1.000 como número mais provável (NMP) de coliformes fecais por cada 100 mililitros e pH entre 5 e 10 unidades. Para os outros parâmetros a concentração é medida na sua forma total (Ex: Nitrogênio Total). Na TABELA 13 são apresentados os demais padrões de emissão. 
TABELA 13 - Limites máximos de concentração estabelecidos como padrão de emissão no México.

\begin{tabular}{|c|c|c|c|c|c|c|c|c|c|c|c|c|c|c|c|}
\hline \multirow[b]{2}{*}{ Tipo } & \multirow[b]{2}{*}{ Corpo Receptor } & \multicolumn{14}{|c|}{ PARÂMETROS E CONCENTRAÇÕES (mg/L) } \\
\hline & & \begin{tabular}{|r|} 
Óleos e \\
Graxas \\
\end{tabular} & SST & DBO & N & $\mathrm{P}$ & $\mathrm{As}_{2} \mathrm{O}_{3}$ & $\mathrm{Cd}$ & $\mathrm{Cu}$ & $\mathrm{Cr}$ & $\mathrm{Hg}$ & $\mathrm{Ni}$ & $\mathrm{Pb}$ & $\mathrm{Zn}$ & $\mathrm{CN}^{-}$ \\
\hline \multirow{3}{*}{ A } & Rios usados para irrigação e aqüíferos & 15,0 & 150,0 & 150,0 & 40,0 & 20,0 & 0,2 & 0,2 & 4,0 & 1,0 & 0,010 & 2,0 & 0,5 & 10,0 & 1,0 \\
\hline & $\begin{array}{l}\text { Águas costeiras com exploração } \\
\text { pesqueira, navegação e outros usos }\end{array}$ & 15,0 & 150,0 & 150,0 & N.A & N.A & 0,1 & 0,1 & 4,0 & 0,5 & 0,010 & 2,0 & 0,2 & 10,0 & 1,0 \\
\hline & Solos utilizados na irrigação & 15,0 & N.A & N.A & N.A & N.A & 0,2 & 0,05 & 4,0 & 0,5 & 0,005 & 2,0 & 5,0 & 10,0 & 2,0 \\
\hline \multirow{5}{*}{ B } & $\begin{array}{l}\text { Rios usados para abastecimento urbano } \\
\text { e aqüíferos }\end{array}$ & 15,0 & 75,0 & 75,0 & 40,0 & 20,0 & 0,1 & 0,2 & 4,0 & 0,5 & 0,005 & 2,0 & 0,2 & 10,0 & 1,0 \\
\hline & $\begin{array}{c}\text { Reservatórios naturais e artificiais } \\
\text { utilizados para irrigação }\end{array}$ & 15,0 & 75,0 & 75,0 & 40,0 & 20,0 & 0,2 & 0,2 & 4,0 & 1,0 & 0,010 & 2,0 & 0,5 & 10,0 & 2,0 \\
\hline & Águas costeiras usadas para recreação & 15,0 & 75,0 & 75,0 & N.A & N.A & 0,2 & 0,2 & 4,0 & 1,0 & 0,010 & 2,0 & 0,5 & 10,0 & 2,0 \\
\hline & Estuários & 15,0 & 75,0 & 75,0 & 15,0 & 5,0 & 0,1 & 0,1 & 4,0 & 0,5 & 0,010 & 2,0 & 0,2 & 10,0 & 1,0 \\
\hline & Várzeas ou pântanos & 15,0 & 75,0 & 75,0 & N.A & N.A & 0,1 & 0,1 & 4,0 & 0,5 & 0,005 & 2,0 & 0,2 & 10,0 & 1,0 \\
\hline C & $\begin{array}{c}\text { Rios utilizados para proteção da vida } \\
\text { aquática, reservatórios naturais e artificiais } \\
\text { utilizados para abastecimento urbano } \\
\text { e aqǘferos }\end{array}$ & 15,0 & 40,0 & 30,0 & 15,0 & 5,0 & 0,1 & 0,1 & 4,0 & 0,5 & 0,005 & 2,0 & 0,2 & 10,0 & 1,0 \\
\hline
\end{tabular}

N.A.: Não se aplica.

Fonte: MÉXICO (2002). 
Assim, a cobrança é aplicada sobre os efluentes que possuam pelo menos um dos parâmetros de poluição fora dos limites do padrão de emissão. Para o cálculo dos valores consideram-se o volume lançado nos últimos três meses e a carga poluidora. Vale ressaltar que, qualquer que seja o caso, a cobrança somente incide sobre volume igual ou superior a $9.000 \mathrm{~m}^{3}$ por trimestre.

A equação (7) apresenta a cobrança para o parâmetro coliforme fecal.

$$
\text { Cobrança }(\mathrm{CF})=\mathrm{V} \text {. \$(Tipo) }
$$

Onde:

Cobrança (CF) = Valor cobrado para o parâmetro coliforme fecal (\$) $\mathrm{V}=$ Volume de efluente lançado no trimestre $\left(\mathrm{m}^{3}\right)$

$\$($ Tipo $)=$ Valor unitário de cobrança em função do tipo de corpo receptor $\left(\$ / \mathrm{m}^{3}\right)$.

Para tipo A o valor é de PESOMX\$ 0,9165 ou US\$ 0,09276; para corpos tipo B e C o valor é de PESOMX\$ 0,4579 ou US\$ 0,04635, de acordo com a cotação de 15/07/2002.

Para o potencial hidrogeniônico $(\mathrm{pH})$, a cobrança também é aplicada sobre o volume lançado de acordo com as faixas de pH apresentadas na TABELA 14.

TABELA 14 - Valores cobrados de acordo as faixas de pH do efluente lançado.

\begin{tabular}{c|c|c}
\hline \multirow{2}{*}{ Faixas em unidades de $\mathrm{pH}$} & \multicolumn{2}{|c}{ Valor Unitário Cobrado $\left(\$ / \mathrm{m}^{3}\right)$} \\
\cline { 2 - 3 } & Peso Mexicano & Dólar* \\
\hline Menor que 5 até 4 & 0,037 & 0,00374 \\
Menor que 4 até 3 & 0,128 & 0,01295 \\
Menor que 3 até 2 & 0,405 & 0,04099 \\
Menor que 2 até 1 & 1,185 & 0,11994 \\
Menor que 1 & 1,644 & 0,16640 \\
Maior que 10 até 11 & 0,202 & 0,02044 \\
Maior que 11 até 12 & 0,630 & 0,06377 \\
Maior que 12 até 13 & 0,896 & 0,09069 \\
Maior que 13 & 1,275 & 0,12905 \\
\hline
\end{tabular}

* Cotação de 15/07/2002.

Fonte: MÉXICO (2002). 
Para os demais parâmetros básicos de poluição (Óleos e Graxas, SST, DBO, N e P), metais pesados e cianetos, a cobrança é dada pela equação (8):

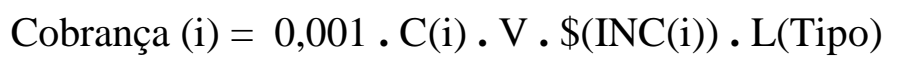

Onde:

Cobrança (i) = Valor cobrado para o parâmetro i $(\$)$

C(i) = Concentração do parâmetro i no efluente lançado (mg/L)

$\mathrm{V}=$ Volume de efluente lançado no trimestre $\left(\mathrm{m}^{3}\right)$

\$(INC(i)) = Valor unitário de cobrança em função do índice de não cumprimento do parâmetro i $(\$ / \mathrm{kg})$

L(Tipo $)$ Fator de localização da descarga em função do tipo de corpo receptor

Nesta formulação o fator de 0,001 é usado para transformar a concentração de $\mathrm{mg} / \mathrm{L}$ para kg/m³ . Além disso, o Índice de Não Cumprimento do parâmetro i (INC(i)) retrata a quantidade de vezes que a concentração do parâmetro no efluente ultrapassa os limites máximos estabelecidos como padrão de emissão. Este índice é obtido por meio da equação (9). Já o fator de localização é estabelecido de acordo com o tipo de corpo receptor: Tipo A, $\mathrm{L}=0,56$; Tipo $\mathrm{B}, \mathrm{L}=1,0$ e Tipo $\mathrm{C}, \mathrm{L}=1,2$.

$$
\operatorname{INC}(\mathrm{i})=[\mathrm{C}(\mathrm{i})-\mathrm{PE}(\mathrm{i})] / \mathrm{PE}(\mathrm{i})
$$

Onde:

INC(i) = Índice de não cumprimento do parâmetro i

C(i) = Concentração do parâmetro i no efluente lançado (mg/L)

PE(i) = Padrão de emissão do parâmetro i (mg/L)

A TABELA 15 apresenta os valores unitários de cobrança de acordo com o INC. Depois de estabelecido os valores de cobrança para todos os parâmetros de poluição encontrados no efluente, inclusive coliformes fecais e $\mathrm{pH}$, os usuários são obrigados a pagar somente o maior valor de cobrança dentre os calculados para cada parâmetro. É interessante destacar que o sistema mexicano leva em conta, de maneira direta, o padrão de emissão. O padrão de qualidade é considerado de forma indireta, por meio do fator de localização. 
TABELA 15 - Valores unitários de cobrança de acordo com INC.

\begin{tabular}{|c|c|c|c|c|}
\hline \multirow{3}{*}{ Faixas de INC } & \multicolumn{4}{|c|}{ Valor Unitário Cobrado (\$/kg) } \\
\hline & \multicolumn{2}{|c|}{ Parâmetros Básicos } & \multicolumn{2}{|c|}{ Metais Pesados e Cianetos } \\
\hline & PESOMX & Dólar & PESOMX & Dólar \\
\hline Maior que 0,00 até 0,10 & 0,00 & 0,000 & 0,00 & 0,00 \\
\hline Maior que 0,10 até 0,20 & 1,64 & 0,166 & 69,59 & 7,04 \\
\hline Maior que 0,20 até 0,30 & 1,96 & 0,198 & 82,61 & 8,36 \\
\hline Maior que 0,30 até 0,40 & 2,20 & 0,223 & 91,37 & 9,25 \\
\hline Maior que 0,40 até 0,50 & 2,35 & 0,238 & 98,12 & 9,93 \\
\hline Maior que 0,50 até 0,60 & 2,51 & 0,254 & 103,68 & 10,49 \\
\hline Maior que 0,60 até 0,70 & 2,61 & 0,264 & 108,45 & 10,98 \\
\hline Maior que 0,70 até 0,80 & 2,73 & 0,276 & 112,69 & 11,41 \\
\hline Maior que 0,80 até 0,90 & 2,78 & 0,281 & 116,48 & 11,79 \\
\hline Maior que 0,90 até 1,00 & 2,91 & 0,295 & 119,95 & 12,14 \\
\hline Maior que 1,00 até 1,10 & 2,96 & 0,300 & 123,08 & 12,46 \\
\hline Maior que 1,10 até 1,20 & 3,08 & 0,312 & 126,05 & 12,76 \\
\hline Maior que 1,20 até 1,30 & 3,13 & 0,317 & 128,80 & 13,04 \\
\hline Maior que 1,30 até 1,40 & 3,17 & 0,321 & 131,38 & 13,30 \\
\hline Maior que 1,40 até 1,50 & 3,28 & 0,332 & 133,79 & 13,54 \\
\hline Maior que 1,50 até 1,60 & 3,31 & 0,335 & 136,12 & 13,78 \\
\hline Maior que 1,60 até 1,70 & 3,34 & 0,338 & 138,31 & 14,00 \\
\hline Maior que 1,70 até 1,80 & 3,42 & 0,346 & 140,41 & 14,21 \\
\hline Maior que 1,80 até 1,90 & 3,46 & 0,350 & 142,41 & 14,41 \\
\hline Maior que 1,90 até 2,00 & 3,48 & 0,352 & 144,29 & 14,60 \\
\hline Maior que 2,00 até 2,10 & 3,58 & 0,362 & 146,15 & 14,79 \\
\hline Maior que 2,10 até 2,20 & 3,62 & 0,366 & 147,93 & 14,97 \\
\hline Maior que 2,20 até 2,30 & 3,65 & 0,369 & 149,64 & 15,15 \\
\hline Maior que 2,30 até 2,40 & 3,69 & 0,373 & 151,30 & 15,31 \\
\hline Maior que 2,40 até 2,50 & 3,72 & 0,377 & 152,93 & 15,48 \\
\hline Maior que 2,50 até 2,60 & 3,76 & 0,381 & 154,47 & 15,63 \\
\hline Maior que 2,60 até 2,70 & 3,80 & 0,385 & 155,96 & 15,79 \\
\hline Maior que 2,70 até 2,80 & 3,84 & 0,389 & 157,43 & 15,93 \\
\hline Maior que 2,80 até 2,90 & 3,88 & 0,393 & 158,86 & 16,08 \\
\hline Maior que 2,90 até 3,00 & 3,92 & 0,397 & 160,23 & 16,22 \\
\hline Maior que 3,00 até 3,10 & 3,97 & 0,402 & 161,58 & 16,35 \\
\hline Maior que 3,10 até 3,20 & 4,00 & 0,405 & 162,91 & 16,49 \\
\hline Maior que 3,20 até 3,30 & 4,02 & 0,407 & 164,21 & 16,62 \\
\hline Maior que 3,30 até 3,40 & 4,05 & 0,410 & 165,46 & 16,75 \\
\hline Maior que 3,40 até 3,50 & 4,08 & 0,413 & 166,68 & 16,87 \\
\hline Maior que 3,50 até 3,60 & 4,12 & 0,417 & 167,86 & 16,99 \\
\hline Maior que 3,60 até 3,70 & 4,13 & 0,418 & 169,02 & 17,11 \\
\hline Maior que 3,70 até 3,80 & 4,16 & 0,421 & 170,20 & 17,23 \\
\hline Maior que 3,80 até 3,90 & 4,19 & 0,424 & 171,30 & 17,34 \\
\hline Maior que 3,90 até 4,00 & 4,20 & 0,425 & 172,42 & 17,45 \\
\hline Maior que 4,00 até 4,10 & 4,22 & 0,427 & 173,50 & 17,56 \\
\hline Maior que 4,10 até 4,20 & 4,24 & 0,429 & 174,58 & 17,67 \\
\hline Maior que 4,20 até 4,30 & 4,30 & 0,435 & 175,60 & 17,77 \\
\hline Maior que 4,30 até 4,40 & 4,32 & 0,437 & 176,65 & 17,88 \\
\hline Maior que 4,40 até 4,50 & 4,35 & 0,440 & 177,65 & 17,98 \\
\hline Maior que 4,50 até 4,60 & 4,40 & 0,445 & 178,64 & 18,08 \\
\hline Maior que 4,60 até 4,70 & 4,41 & 0,446 & 179,61 & 18,18 \\
\hline Maior que 4,70 até 4,80 & 4,42 & 0,447 & 180,56 & 18,28 \\
\hline Maior que 4,80 até 4,90 & 4,44 & 0,449 & 181,53 & 18,37 \\
\hline Maior que 4,90 até 5,00 & 4,46 & 0,451 & 182,46 & 18,47 \\
\hline Maior que 5,00 & 4,49 & 0,454 & 183,37 & 18,56 \\
\hline
\end{tabular}

Fonte: MÉXICO (2002). 
Estão isentos do pagamento da cobrança sobre lançamento de efluentes os usuários que respeitarem o padrão de emissão; os usuários que lançarem em redes de coleta que não sejam bens de domínio público; os usuários que devolvam à fonte original de onde foi extraída a água, desde que apresentem um certificado da CNA atestando que a água não sofreu mudanças em sua qualidade e sua temperatura. Esta última situação apresenta ambigüidade, entretanto, cobre aqueles usuários que usam águas altamente poluídas.

São isentas ainda: populações rurais menores que 2.500 habitantes e os serviços de água e esgoto correlatos; descargas provenientes da irrigação; entidades sem fins lucrativos que prestem serviços de assistência médica, social ou de educação escolar gratuita em benefício de comunidades rurais inferiores a 2.500 habitantes; usuários domésticos localizados em áreas carentes de serviço de coleta; e usuários que apresentem, à Comissão Nacional da Água (CNA), um programa de ações para melhoria da qualidade de suas águas residuárias, com finalidade de não ultrapassar os limites estabelecidos como padrão de emissão. Neste último caso, o usuário deve prestar esclarecimentos periódicos a respeito do desenvolvimento e dos resultados dos programas. Caso contrário, é efetuada a cobrança sobre efluentes lançados nos dois últimos trimestres nos quais o usuário foi isento.

Os usuários que contem com estações de tratamento de águas residuárias ou que tenham investido na racionalização do processo produtivo - a fim de melhorar a qualidade de seus efluentes - poderão obter descontos na cobrança sobre captação de água, desde que os parâmetros poluentes apresentem concentrações bem inferiores às do padrão de emissão. Esse benefício é válido somente para usos de águas nacionais que gerem descarga de águas residuárias.

Apesar de essa metodologia de cobrança sobre lançamento de águas residuárias ser uma espécie de multa por não atendimento, ela pode ser ajustada para incidir sobre qualquer grau de poluição, não somente naqueles acima do padrão de emissão. Da maneira como está, o sistema serve ao controle de uma regulação que é o padrão de emissão. Entretanto, é preciso inserir no sistema, de maneira clara, os aspectos relativos ao padrão de qualidade dos corpos de água, pois é ele que retrata o estado das águas, que nem sempre apresentarão boa qualidade pelo simples cumprimento isolado do padrão de emissão. 


\subsection{Considerações dos casos internacionais}

O sistema francês de cobrança tem por base o rateio de custos de investimento na recuperação ambiental da bacia, na qual os recursos foram gerados, portanto, visa a viabilidade financeira. Porém, ainda que econômico, a finalidade dos instrumentos de gestão ambiental deve ser a gestão do recurso natural e não a arrecadação. Assim, em um sistema de cobrança, os valores propostos devem refletir o comprometimento apresentado pelo corpo de água, capacidade de oferta hídrica e qualidade desejada para ele - não o valor de uma conta a ser paga.

A metodologia francesa considera alguns parâmetros que procuram atender ao preceito da escassez relativa. Entretanto, aplica valores de cobrança mais elevados sobre lançamentos em meio receptor com capacidade de assimilação maior, ou seja, o sistema incentiva o usuário a descarregar seus efluentes em corpos de água mais saturados (comprometidos em termos de qualidade). Ademais, encoraja a ocupação do solo em regiões mais adensadas, uma vez que, corpos hídricos de pouca qualidade normalmente estão próximos a essas regiões.

Na França os valores de cobrança praticados não induziram ao comportamento racional dos usuários. Mesmo assim, houve melhoria na qualidade das águas, devido aos investimentos feitos para esse objetivo. Outros fatores concorreram para que esse objetivo fosse alcançado, como: regulamentação relativa aos rejeitos poluentes e auxílio financeiro fornecido pelas Agências de Bacia na forma de subsídios. Percebese, portanto, que a cobrança possui caráter corretivo, pois a poluição só é suprimida por meio de investimentos realizados com a arrecadação.

Na Alemanha, a cobrança sobre captação é diretamente atrelada ao sistema de licenças para esse uso. Os critérios considerados são uniformes para todas as regiões, portanto, não considera a escassez relativa da água. Em parte, isso pode ser explicado pelo fato de a outorga da licença levar em conta a possibilidade de comprometimento da qualidade do corpo de água. Nesse caso, somente a aplicação da licença garante a manutenção de uma situação ecológica aceitável.

O sistema alemão de cobrança sobre lançamento de efluentes também funciona atrelado ao sistema de licenciamento que, nesse caso, fixa o padrão de emissão a ser observado pelo usuário. A cobrança é efetuada sobre qualquer quantidade lançada, 
porém, caso o padrão de emissão seja atendido, há descontos no valor cobrado. Vale ressaltar, no entanto, que a observância isolada do padrão de emissão não garante o atendimento ao padrão de qualidade do corpo de água receptor.

O atual arranjo institucional da gestão das águas na Inglaterra e País de Gales data de 1996, com a criação da Environment Agency (EA). Apesar de esse sistema de gestão considerar as bacias hidrográficas como unidade de planejamento, verifica-se a centralização das funções de gestão no Poder Público Federal.

A cobrança sobre usos da água na Inglaterra e País de Gales foi introduzida em 1993. Esse instrumento é atrelado ao licenciamento das captações e lançamentos de efluentes. As licenças existem desde 1965 e são consideradas o principal instrumento de controle dos usos da água. O objetivo da cobrança é a recuperação dos custos de regulação do sistema de gestão das águas, ou seja, a arrecadação. A cobrança não retrata o real valor do recurso hídrico, apesar da sua formulação considerar alguns parâmetros (não todos) coerentes com o preceito da escassez relativa.

A gestão das águas na Austrália passa por revisão profunda, desde a introdução dos instrumentos econômicos como mecanismo de alocação dos recursos hídricos. Em todo o país são encontradas diversas experiências na utilização da cobrança sobre usos da água e dos mercados de direitos de uso e poluição. Todavia, é difícil avaliar os ganhos da adoção desses instrumentos. Cabe ressaltar, entretanto, que a cobrança sobre captação adotada no Estado de New South Wales objetiva a recuperação dos custos dos serviços de oferta de água. Portanto, sua aplicação é questionável como instrumento econômico de gestão.

A alocação de água, para atender as necessidades ambientais, é outro aspecto importante que deve ser destacado na experiência australiana. A discussão a respeito das “vazões ecológicas”, passa pela análise dessa peculiaridade da gestão de recursos hídricos na Austrália.

No Chile, o mercado de direitos de uso da água é utilizado, como instrumento econômico, desde 1951. Entretanto, durante esse período, o sistema sofreu algumas intervenções. Atualmente, o comércio das águas é efetivo somente entre irrigantes; poucas transações são realizadas entre diferentes setores usuários, pois ainda existem diversos impedimentos de ordem legal e institucional. 
A proposta de Política Nacional de Recursos Hídricos do Chile traz a reboque várias recomendações, que podem tornar o mercado de direitos de uso da água efetivo para todos os setores usuários. A política prevê novo arranjo do sistema de outorga dos direitos de uso; além disso, reconhece a importância da gestão integrada, descentralizada e participativa.

O sistema mexicano de cobrança sobre captação não deixa claro o critério de diferenciação das zonas de disponibilidade. Contudo, relativa à questão quantitativa, a cobrança sobre captação atua mais fortemente em regiões de alta demanda para abastecimento e usos industriais. Dessa maneira, esse sistema reconhece o preceito da escassez relativa.

No México a cobrança sobre lançamento de efluentes experimentou grandes transformações durante o período de 1991 a 1997. Atualmente, o sistema estabelece a cobrança sobre concentrações acima do padrão de emissão, portanto, é considerada multa por não atendimento de regulação. Apesar disso, trata-se de metodologia que pode ser ajustada para incidir sobre qualquer nível de poluição. 


\section{Duas experiências brasileiras em gestão das águas e os instrumentos econômicos}

Neste capítulo são apresentadas e analisadas duas experiências brasileiras em gestão das águas, principalmente no que diz respeito à utilização dos instrumentos econômicos. No primeiro caso aborda-se a experiência do Ceará, primeiro Estado a implantar a cobrança sobre usos da água e possuidor de arranjo institucional peculiar. No segundo caso apresenta-se a evolução institucional que o Estado de São Paulo tem experimentado, principalmente por ter sido o primeiro Estado a possuir uma política de gestão de recursos hídricos; apresenta-se ainda, a proposta paulista de implementação da cobrança, que tramita na Assembléia Legislativa para aprovação. Ao final do capítulo são feitas algumas considerações sobre estes casos.

\subsection{Caso do Ceará}

A gestão das águas no Estado do Ceará sempre se caracterizou por possuir forte intervenção federal. Por meio do DNOCS*, a política das águas era definida e executada; assim, foram feitos grandes investimentos em infra-estrutura hídrica para combate às secas. A partir da década de 80 , o Estado reconheceu que deveria atuar de maneira relevante em políticas de gestão das águas e, desta forma, a Secretaria de Recursos Hídricos (SRH) conduziu a realização do Plano Estadual de Recursos Hídricos, passo inicial para a política de águas no Estado. Neste plano foi previsto o arranjo institucional do sistema de gestão, que tem sido implementado desde 1992, e dele foi gerada a Política Estadual dos Recursos Hídricos (Lei $n^{0}$ 11.996/92) que prevê a cobrança pelo uso da água bruta.

A política cearense de recursos hídricos, entre suas várias realizações, em 1993 criou a Companhia de Gestão de Recursos Hídricos (COGERH), agente técnico do

\footnotetext{
* Departamento Nacional de Obras Contra Seca
} 
Sistema Integrado de Gestão dos Recursos Hídricos (SIGERH), com competência administrativa sobre todo e qualquer fornecimento de água bruta proveniente dos mananciais superficiais e subterrâneos que integram o sistema de oferta dos recursos hídricos do Estado. Portanto, compete à COGERH ser o suporte institucional para aplicação dos instrumentos necessários a gestão dos recursos hídricos e, entre eles, está a cobrança sobre usos da água.

No Ceará, a bacia hidrográfica é adotada como unidade de planejamento e gestão. O amadurecimento da unidade de gestão e a participação efetiva da sociedade têm levado à formação dos respectivos Comitês de Bacia. Nesse tocante, a COGERH atua como uma Agência de Bacia.

Esta estrutura centralizada difere de outros modelos institucionais adotados em Estados brasileiros. Além disso, é contrária ao que se deve observar em uma gestão ambiental obediente aos preceitos da sustentabilidade, mais especificamente, quando são consideradas as especificidades locais.

Neste contexto, ALVARES DA SILVA \& BEZERRA (2001) confirmam que a COGERH tem atuado como se fosse uma agência estadual, uma vez que realiza várias atribuições pertinentes a uma Agência de Bacia. Os autores admitem ser pouco provável que as bacias do Ceará tenham condições econômicas de implantar agências de água, nos moldes previstos na Política Nacional de Recursos Hídricos. Entretanto, os autores op. cit. admitem que a instalação dos Comitês de Bacia e as crescentes demandas de gerenciamento e mediação de conflitos de uso da água, geraram a necessidade de descentralização das atribuições da COGERH. Assim, optou-se pela criação de unidades descentralizadas, denominadas Gerências de Bacia.

Foram criadas 6 Gerências de Bacia para as 11 bacias hidrográficas do Ceará, divididas da seguinte maneira: Gerência do Curu e Litoral; Gerência do Banabuiú, Médio e Baixo Jaguaribe; Gerência do Alto Jaguaribe; Gerência do Salgado, Gerência do Parnaíba e Gerência do Acaraú e Coreaú. Para o caso das Bacias Metropolitanas, optou-se pela criação de uma Superintendência interna à COGERH. (ALVARES DA SILVA \& BEZERRA, 2001)

Sobre a metodologia de alocação da água praticada no Estado, ARAÚJO e SOUZA (1999) afirmam que ela pressupõe a organização dos usuários e o apoio técnico do órgão gestor - COGERH. Isto, de alguma forma, já é observado, pois a 
cada ano, no início do período de estiagem, são realizados seminários para cada bacia e/ou vale com vistas a definição das vazões a serem liberadas de cada reservatório; regulamentação dos volumes outorgados entre usuários - por meio de um processo de negociação; emprego de medidas de controle de quantidade e qualidade da água.

TEIXERA et al. (1999) comentam que o processo de apoio à organização dos usuários leva em consideração três situações:

- Açude: nível básico de organização dos usuários. Neste caso, pescadores, vazanteiros, irrigantes e mesmo o abastecimento das cidades dependem de um mesmo reservatório de água. Neste nível, é apoiado o fortalecimento ou a constituição de associações de usuários.

- Vale perenizado: nível um pouco mais complexo de atuação que envolve um ou mais açudes e trechos de rios perenizados onde se localizam, normalmente, os grandes perímetros públicos irrigados, irrigantes privados, agroindústrias, indústrias e abastecimento de várias cidades. Neste nível são constituídas as comissões de usuários das águas dos vales perenizados.

- Bacia Hidrográfica: nível de atuação mais complexo que abrange toda a área da bacia, entendida como unidade de planejamento e gestão, com todos os conflitos e potencialidades. A partir da consolidação do processo de organização dos dois níveis anteriores (açudes e vales perenizados), são constituídos os Comitês de Bacia visando a concretização do processo de gestão participativa dos recursos hídricos.

A primeira experiência no âmbito de bacia hidrográfica foi a constituição do Comitê da Bacia Hidrográfica do Curu em 1997. A sua origem teve como núcleo básico a Comissão dos Usuários do Vale do Curu. Atualmente o Comitê do Curu conta com 50 membros, dividido em 04 setores: usuários (15 membros), sociedade civil (15 membros), poder público municipal (10 membros) e poder público estadual e federal (10 membros). Apresenta ainda três Comissões permanentes: Estudos e Planejamento; Operação e Gerenciamento; e Meio Ambiente e Educação Ambiental. (ALVARES DA SILVA \& BEZERRA, 2001)

Com objetivo de sistematizar informações e fornecer subsídios aos Comitês de Bacia nas decisões que lhes cabe, têm sido realizados estudos na busca de adequar o uso, o controle e a preservação das águas às necessidades sociais e governamentais, 
identificadas nas diversas bacias hidrográficas. Neste sentido, o Plano Estadual de Recursos Hídricos é periodicamente atualizado, e são realizados investimentos para a formulação dos Planos de Gerenciamento das Bacias Hidrográficas e do Sistema de Suporte à Decisão Espacial, desenvolvidos pela COGERH. (TEIXEIRA et al., 1999)

Percebe-se que a aplicação dos instrumentos propostos na política das águas no Ceará tem sido acompanhada de uma base de informações ampla, principalmente por meio do desenvolvimento do monitoramento - outro instrumento de gestão. Neste sistema são considerados aspectos quantitativos e qualitativos que servem à tomada de decisão na fase de operação (principalmente a definição da vazão a ser liberada pelos açudes). Atualmente, a COGERH gerencia 108 açudes públicos, parte em convênio com o DNOCS, com capacidade total de acumulação de 10,3 bilhões de metros cúbicos, o que representa cerca de $85 \%$ da capacidade total de acumulação de água do Estado. Estes açudes são responsáveis pela perenização de 1.938 km de rios intermitentes do Ceará. (MACEDO, 2000)

O financiamento de toda a estrutura técnica e administrativa da COGERH é garantido, parcialmente, pela cobrança sobre captação. No Ceará este instrumento econômico de gestão das águas é aplicado como fonte de arrecadação para cobrir os custos administrativos da entidade encarregada de aplicá-lo. A definição dos valores e a aplicação restrita a certos usuários não consideram as especificidades ambientais locais - relativas principalmente à escassez do recurso hídrico.

No Estado não existe cobrança sobre lançamento de efluentes. Apesar disso, ARAÚJO \& SOUZA (1999) propõem algumas medidas, as quais poderiam servir ao controle do lançamento de águas residuárias. Citam-se: o cadastro e o inventário de fontes de emissão (inclusive esgoto doméstico), caracterização deste efluente e análise de sua adequação frente a padrões de emissão, considerada a Resolução CONAMA n ${ }^{0}$ 20/86 e o enquadramento dos corpos de água.

Os autores op.cit. comentam a necessidade do controle de cargas difusas, haja vista que o assoreamento dos açudes e a poluição das águas por produtos agrícolas e resíduos de atividades agropecuárias são observados com freqüência no Estado. Cabe destacar que estas ações sugeridas, caso postas em prática, dotariam o Ceará de subsídios fundamentais a uma possível cobrança sobre lançamento de efluentes. 


\subsubsection{Formação do valor cobrado no Ceará}

Em 1996, o governo do Ceará, por meio do Decreto nº 24.264, estabeleceu as tarifas de cobrança para usos e usuários industriais, e concessionárias de serviços de abastecimento. As tarifas seriam aplicadas pela COGERH sobre as águas superficiais e subterrâneas de domínio do Estado, observada a outorga concedida pela Secretaria dos Recursos Hídricos (SRH). A tarifa fixada para as indústrias - R\$ 0,60/m³ - era equivalente a cerca de $50 \%$ do valor da água tratada fornecida pela Companhia de Água e Esgoto do Ceará (CAGECE), e só deveria ser aplicada sobre usos industriais superiores a $70 \mathrm{~m}^{3} /$ mês. Para as concessionárias de abastecimento, a tarifa fixada foi de $\mathrm{R} \$ 0,01 / \mathrm{m}^{3}$, equivalente a $1 / 60$ da tarifa para as indústrias.

RIBEIRO \& LANNA (1997) comentam que, “aparentemente estes valores foram arbitrados mais em função de negociações com os usuários do que em função de outras referências econômicas ou financeiras. Esta cobrança, no entanto, não pode ser considerada pela retirada de água bruta, pois, no semi-árido, a água só pode ser disponibilizada pela implantação de reservatórios - sendo assim, a COGERH estaria cobrando a água como contrapartida pelo serviço de sua disponibilização, a partir dos reservatórios que opera e dos que planeja construir”.

Como se percebe, o método de cobrança no Ceará não pode ser considerado um instrumento econômico de gestão. É somente uma forma de arrecadação de recursos, que, por vezes, não são aplicados em investimentos, mas sim na administração do sistema, operação e manutenção da infra-estrutura existente. Os valores adotados são desprovidos de qualquer referência ambiental, e têm por base somente o custo da água tratada pela CAGECE.

Em dezembro de 1997, preservando o estabelecido em 1996, definiram-se os critérios que orientam a atual política global da tarifa de água bruta estadual:

- Uso Industrial - 50\% do valor da água tratada fornecida pela CAGECE para o uso industrial com consumo superior a $70 \mathrm{~m}^{3} /$ mês.

- Concessionárias de abastecimento de água potável - 1/60 (um sessenta avos) da tarifa para os usuários industriais de água bruta. 
- Irrigação, piscicultura e aqüicultura (utilização do espelho d’água) - a tarifa será estabelecida pelo Comitê de Bacia. Caso não haja Comitê, o valor será aquele estabelecido pela COGERH após discussão com usuários destas bacias. Em todos os casos, o valor para a irrigação deverá ser, no mínimo, equivalente 1/600 (um seiscentos avos) do valor para os usuários industriais de água bruta.

- Usuários de água pressurizada ou conduzida em canais - as tarifas serão fixadas para cada sistema, por meio de portaria do Secretário de Recursos Hídricos.

Em dezembro de 1999, foi editado o Decreto $n^{0} 25.721$, o qual reajustou os valores a serem cobrados. Para concessionárias de abastecimento foi estabelecido o valor de $\mathrm{R} \$ 0,013 / \mathrm{m}^{3}$ e para usos industriais o valor de $\mathrm{R} \$ 0,67 / \mathrm{m}^{3}$. Cabe destacar que para concessionárias de abastecimento que utilizam água do Sistema Integrado Metropolitano (fonte de abastecimento da capital Fortaleza) este valor é de R\$ $0,028 / \mathrm{m}^{3}$, no qual, está incluso o custo referente ao consumo de energia elétrica nas estações de bombeamento do referido sistema.

A cobrança sobre a irrigação no Ceará ainda é incipiente e aplicada somente em quatro sistemas de oferta hídrica: Açude Acarape do Meio, Canal do Trabalhador e nos vales do rio Jaguaribe e do Banabuiú. A cobrança nos dois primeiros sistemas faz parte de negociação entre irrigantes e a COGERH, neles os valores cobrados variam entre $\mathrm{R} \$ 0,004 / \mathrm{m}^{3}$ e $\mathrm{R} \$ 0,02 / \mathrm{m}^{3}$. No baixo Jaguaribe o sistema de cobrança foi implementado em 2001 em convênio com a Agência Nacional de Águas (ANA), que estipulou o valor de $\mathrm{R} \$ 0,01 / \mathrm{m}^{3}$. Com o dinheiro arrecadado a ANA pretende indenizar, a cada ano, os agricultores que venham a ficar sem água para produzir, desde que troquem a lavoura de arroz por outras de valor agregado maior e menos indutoras de água.

Apesar da tarifa para uso com irrigação não ter sido implementada de forma ampla, existem estudos acerca da matéria, entre os quais, cita-se ARAÚJO (1996). A partir de estudo realizado por Lanna em 1994, o autor propôs um modelo de cobrança pelo uso da água para irrigação - baseado no custo médio da água bruta da bacia. O modelo considera a recuperação financeira dos investimentos em infraestrutura, para um período de retorno de 50 anos e juros de $8 \%$ ao ano. 
O modelo leva em conta uma forma de subsídio cruzado, a área irrigável e o volume de água utilizado. Nele há a possibilidade de escolha, por parte do tomador de decisão, da área limite que levaria o usuário a ter o subsídio ou a sobretarifação. A equação (10) representa o modelo proposto por ARAÚJO (1996).

$$
\text { Tarifa }=\mathrm{S} 1 . \mathrm{A}+\$ \mathrm{a} \cdot \mathrm{V}
$$

Onde:

S1 = Subsídio

A = Área irrigável

\$a = Custo médio da água bruta da bacia

$\mathrm{V}=$ Volume utilizado

A aplicação deste modelo foi feita para a bacia do rio Curu, e os resultados mostraram que ele "pune" propriedades improdutivas, por meio de altos custos unitários. Propriedades com altas taxas de uso da terra teriam custo médio próximo à média da bacia.

Cabe destacar que apesar da cobrança sobre irrigação ser recente e restrita a poucas áreas, existe por parte dos agricultores uma relevante disposição a pagar pela água, desde que a oferta hídrica seja garantida durante o ano todo.

Ainda sobre o modelo tarifário mencionado, GARRIDO (2000) comenta que a sua utilização poderá causar distorções na alocação da água entre os irrigantes e incentivar seu consumo excessivo, pois estimularia os agricultores a utilizarem todas suas terras irrigáveis, mesmo não havendo viabilidade para tal uso.

Todavia, entendida essa viabilidade como ambiental, isso não seria verdadeiro. O fato de o cálculo ser baseado em terras classificadas como irrigáveis, imaginando critérios adequados para esta classificação, já garante essa viabilidade e, além disso, utiliza a cobrança para integrar a gestão dos recursos água e solo.

Por outro lado, entendida como econômica, de fato isso poderá ocorrer, pois o valor cobrado onera, por demais, propriedades improdutivas (que passariam a ter que irrigar para diminuir seu custo unitário com água). Entretanto, a improdutividade pode estar relacionada à falta de mercado para os produtos ou, à não disponibilidade de água suficiente para atingir toda a área irrigável. Esta segunda hipótese levaria a grande contradição, uma vez que o sistema de gestão puniria o usuário por existir deficiência do próprio sistema. 
Recentemente, a Secretaria de Recursos Hídricos (SRH) firmou acordo com o Banco Mundial para a realização de estudo, cujo objetivo é definir e implementação da política tarifária de água bruta no Estado do Ceará. Este estudo prevê a cobrança sobre captação e lançamento de efluentes. Cabe destacar que, este é o primeiro passo que o Estado dá na definição de sistema de cobrança sobre lançamento de efluentes. Ressalta-se que o modelo previsto é o de SOUZA (1995), o mesmo utilizado para o estudo de caso dessa dissertação.

\subsection{Caso de São Paulo}

O Estado de São Paulo possui um quadro crítico de escassez quantitativa e qualitativa dos recursos hídricos. As bacias hidrográficas do Alto Tietê, Piracicaba, Turvo Grande e Mogi-Guaçu são as mais comprometidas em relação a oferta quantitativa, com índices abaixo de $1.500 \mathrm{~m}^{3} / \mathrm{hab} / \mathrm{ano}$. A premente necessidade de administrar esse cenário de escassez fez com que, em meados dos anos 80, o Estado considerasse o desenvolvimento do Sistema Estadual de Recursos Hídricos.

A evolução na forma de administrar as águas neste Estado teve início em 1985. Naquele ano, o Departamento de Águas e Energia Elétrica (DAEE) - órgão estadual responsável pelo gerenciamento quantitativo das águas, promoveu a descentralização administrativa por meio da criação de Diretorias de Bacias Hidrográficas.

Em 1987, o Decreto Estadual n ${ }^{0} 27.576$ criou o Conselho Estadual de Recursos Hídricos (CRH) e o Comitê Coordenador do Plano Estadual de Recursos Hídricos (CORHI). Eram objetivos do CRH: formulação da Política Estadual de Recursos Hídricos, elaboração do Plano Estadual de Recursos Hídricos e proposta de estruturação do Sistema de Gestão dos Recursos Hídricos do Estado.

CONEJO (2000) ressalta que, neste processo evolutivo, um grande avanço foi alcançado quando da inclusão - na Constituição do Estado de São Paulo de 1989 dos artigos 205 a 213 - todos eles dedicados exclusivamente aos recursos hídricos. O artigo 205 determina a instituição, por intermédio de lei, de um sistema integrado de gerenciamento de recursos hídricos, congregando órgãos estaduais e municipais e a sociedade civil, cabendo ao Estado assegurar meios financeiros e institucionais para consecução dos objetivos. Para isso, foi acrescentado o artigo 211, que assim dispõe: 
“Art. 211. Para garantir as ações previstas no artigo 205, a utilização dos recursos hídricos será cobrada segundo as peculiaridades de cada bacia hidrográfica, na forma da lei, e o produto aplicado nos serviços e obras referidos no inciso I, do parágrafo único, deste artigo".

"I - em serviços e obras hidráulicas e de saneamento de interesse comum, previstos nos planos estaduais de recursos hídricos e de saneamento básico”.

Em fevereiro de 1991, foi sancionado o primeiro Plano Estadual de Recursos Hídricos, em dezembro do mesmo ano foi aprovada a Política Estadual de Recursos Hídricos (Lei 7.663), que estabeleceu o Sistema Integrado de Gerenciamento de Recursos Hídricos (SIGRH). No Brasil, a Lei 7.663 foi pioneira no trato da gestão das águas; antecedeu, inclusive, a Política Nacional de Recursos Hídricos (Lei Federal 9.433) - publicada em janeiro de 1997.

A estrutura do SIGRH está fundamentada em três instâncias: a instância consultiva/deliberativa, representada pelo Conselho Estadual de Recursos Hídricos (CRH) e Comitês de Bacias Hidrográficas (CBHs); a instância técnica, constituída do Comitê Coordenador do Plano Estadual de Recursos Hídricos (CORHI); e a instância executiva, constituída das Agências de Bacia. Para dar suporte financeiro à Política Estadual de Recursos Hídricos e suas realizações, pela Lei 7.663 foi criado o Fundo Estadual de Recursos Hídricos (FEHIDRO), regulamentado em 1993.

Segundo CONEJO (2000), devido a esse novo arcabouço institucional, ocorreu um rearranjo administrativo no ano de 1993, com a criação da Secretaria de Recursos Hídricos, Saneamento e Obras. Cabe a esta secretaria o planejamento e execução das políticas estaduais de recursos hídricos e de saneamento. A ela estão vinculados o Conselho Estadual de Recursos Hídricos (CRH), DAEE, Companhia de Saneamento Básico do Estado de São Paulo (SABESP) e o FEHIDRO.

Ainda em 1993, foi instalado o CRH - órgão superior do sistema constituído de forma paritária por representantes do Estado (Secretárias de Estado), dos Municípios (Prefeitos) e da Sociedade Civil. Cada segmento representativo tem direito a 11 (onze) votos. Em novembro de 1993, uma deliberação do CRH aprovou as normas gerais para composição, organização, competência e funcionamento dos Comitês de Bacias Hidrográficas (CBHs), com composição tripartite e paritária das mesmas 
classes integrantes do CRH. Ao final do mesmo ano foi instalado o primeiro Comitê - o Comitê das Bacias Hidrográficas dos rios Piracicaba, Capivari e Jundiaí.

Em 1994 foi promulgada a Lei 9.034, relativa ao segundo Plano Estadual de Recursos Hídricos, referente ao período 1994/1995. Esta lei aprovou a divisão do Estado em 22 Unidades Hidrográficas de Gerenciamento de Recursos Hídricos (UGRHI). Neste plano, mencionou-se ainda a caracterização dos Programas de Ação Continuada (PDC), os requisitos de conteúdo de Relatórios de Situação dos Recursos Hídricos, além de recomendações à elaboração dos Planos de Bacias Hidrográficas.

Em 1998 ocorreu outra evolução importante na regulamentação do SIGRH. Foi aprovada a Lei 10.020, que cria as Agências de Bacias Hidrográficas. Sua criação é dada por decisão dos respectivos Comitês e aprovação do CRH. Cabe às Agências ser o suporte técnico, administrativo e financeiro dos Comitês; dentre suas funções destaca-se: "fornecer subsídios ao Comitê de Bacia para que este delibere sobre a cobrança pela utilização das águas” (art. 4, VI); “efetuar a cobrança pela utilização dos recursos hídricos da Bacia de domínio do Estado, na forma fixada pela lei” (art. $\left.4^{\mathrm{o}}, \mathrm{VIII}\right)$

Recentemente, foi aprovado o terceiro Plano Estadual de Recursos Hídricos referente ao período 2000/2003. Neste plano um dos objetivos propostos para uso dos recursos arrecadados com a cobrança é “orientar a localização de atividades econômicas grandes usuárias ou potencialmente poluidoras das águas nas bacias hidrográficas ou em áreas adequadas, em termos de disponibilidade hídrica ou padrões de qualidade, considerando-se o planejamento e o zoneamento ambientais”.

Deste modo, a legislação reconhece a importância que os recursos arrecadados da cobrança podem ter no ordenamento de uso do solo. Entretanto, um maior passo poderá ser dado quando os legisladores reconhecerem o valor do instrumento em si, e não somente da sua arrecadação.

A Lei 7.663/91 está sendo regulamentada por partes e a implementação do novo arranjo institucional tem sido feita de modo gradual. Cabe destacar que no Estado existem 20 Comitês instalados, cobrindo-o completamente, uma vez que dois dos Comitês abrangem duas Unidades Hidrográficas de Gerenciamento de Recursos Hídricos (UGRHI). Destaca-se também que as Agências de Bacia estão em processo de implementação. 
Referente aos instrumentos de gestão considerados pela Lei 7.663, destaca-se que a outorga de direitos de uso da água e as penalidades aplicadas aos infratores da legislação já foram regulamentadas (Decreto 41.258/96; Portaria DAEE nº 717 /96 e Portaria DAEE $n^{0}$ 01/98). Com relação à cobrança pelo uso dos recursos hídricos e o rateio de custos das obras, são instrumentos que ainda precisam ser regulamentados. A regulamentação da cobrança tramita na Assembléia Legislativa para votação desde 1998, por meio do projeto de lei $\mathrm{n}^{0} 20$ de 1998 (PL 20/98), e atualmente pelo projeto de lei $n^{0} 676$ de 12/12/2000 (PL 676/00).

De acordo com CONEJO (2000), o PL 20/98 de regulamentação da cobrança no Estado de São Paulo passou por extenso processo de discussão, no âmbito dos comitês e audiências públicas. O autor relata os princípios fundamentais acordados nesse processo:

- O produto da cobrança deve ser creditado em sub-contas do Fundo Estadual de Recursos Hídricos (FEHIDRO), correspondentes às bacias em que for arrecadado, ou ainda, repassado ao mesmo Fundo, quando feita a cobrança pelas Agências de Bacias e administrado por essas entidades.

- Descentralização: é da própria bacia a decisão sobre alocação dos recursos oriundos da cobrança pelo uso dos recursos hídricos na bacia hidrográfica, mediante deliberações do Comitê. Existe a possibilidade de alocação de até $50 \%$ dos recursos fora da bacia, por deliberação do Comitê, desde que o investimento redunde em benefício para a bacia.

- Vinculação: a cobrança pelos usos dos recursos hídricos está vinculada à implementação de programas, projetos, serviços e obras, de interesse coletivo, previstos nos Planos Estaduais de Recursos Hídricos e de Saneamento Básico, aprovados pelos respectivos Comitês de Bacia e pelo Conselho Estadual de Recursos Hídricos.

- Forma de implementação: a implantação da cobrança deve ser feita com participação dos Comitês de Bacia, de forma gradativa e com a organização de um cadastro específico de usuários de recursos hídricos.

- Valores da cobrança: a fixação dos valores para cobrança pela utilização dos recursos hídricos deve obedecer ao seguinte procedimento: 
Estabelecimento, pelo Conselho Estadual de Recursos Hídricos, dos limites e das condicionantes;

$\checkmark$ Proposta, pelos Comitês de Bacia, dos programas quadrienais a serem efetivamente realizados, das parcelas de investimentos a serem cobertos com o produto da cobrança, e dos valores a serem cobrados na Bacia;

$\checkmark$ Referendo, pelo Conselho Estadual de Recursos Hídricos, das propostas dos Comitês, dos programas quadrienais de investimentos e dos valores da cobrança;

$\checkmark$ Aprovação e fixação dos valores a serem aplicados em cada Bacia, por decreto do governador do Estado.

- Bases da cobrança: a fixação dos valores a serem cobrados tem por base o volume de água captado - extraído ou derivado, o volume consumido (água não devolvida à bacia) e a carga dos efluentes lançados em corpos de água.

Apesar de todo o processo de discussão a respeito da instituição da cobrança como instrumento econômico de gestão das águas no Estado de São Paulo, verificase ainda a existência de forte resistência dos setores industrial e agrícola.

Desta maneira, ao final do exercício de 2000, o PL 20/98 foi retirado e, imediatamente, um novo texto de projeto de lei (PL 676/00) foi encaminhado à Assembléia Legislativa. Este novo projeto foi resultado das rodadas de negociação realizadas, principalmente, com os setores supracitados e representantes do Fórum Paulista da Sociedade Civil nos Comitês de Bacia.

\subsubsection{Proposta de formação do valor a ser cobrado em São Paulo}

A proposta de implantação da cobrança sobre usos da água no Estado de São Paulo é derivada de estudos que começaram a ser realizados em 1992. O primeiro estudo foi efetuado pela Fundação do Desenvolvimento Administrativo (FUNDAP), integrante da Administração Indireta do Estado, e contou também com a participação de técnicos do FUNDAP, do DAEE e consultores das áreas jurídica, institucional e econômica. BARTH (2000)

Esse estudo propôs para a cobrança os seguintes objetivos básicos: redistribuir custos de maneira mais eqüitativa; gerenciar a demanda, aumentando a produtividade 
e eficiência na utilização dos recursos hídricos; alimentar fundo financeiro necessário ao plano regional de recursos hídricos; e fomentar o desenvolvimento regional integrado, especialmente em suas dimensões social e ambiental.

GARRIDO (2000) comenta que a metodologia utilizada nesse primeiro estudo considerava os princípios usuário-pagador e poluidor-pagador, por meio do rateio de custos de investimentos entre os setores usuários, adotando-se o custo médio como referência para cobrança. Todavia, para o caso do lançamento de efluentes, a fixação dos valores era baseada nos custos marginais de longo prazo - metodologia também empregada para o caso da captação de água pelas indústrias.

Segundo BARTH (2000), a maior contribuição do trabalho realizado em 1992 foi a preparação de uma equipe multidisciplinar que estivesse apta a discutir o tema, bem como acompanhar e supervisionar os estudos detalhados que seriam realizados posteriormente. Assim, como grande subsídio ao processo de discussão da cobrança, o DAEE, em 1994, contratou o Consórcio formado pela empresa de consultoria Consórcio Nacional de Engenheiros Consultores (CNEC) e pela Fundação Instituto de Pesquisas Econômicas (FIPE). Nesse estudo, foram apresentadas e caracterizadas metodologias alternativas de cobrança.

Segundo BARTH (2000), a proposta dos consultores deu ênfase à metodologia de rateio de planos de investimentos. Entretanto, em debates realizados sobre essa questão, defendeu-se que a cobrança deveria ser, essencialmente, um instrumento de gestão e não apenas fonte de arrecadação para financiamento de obras. O resultado final desse estudo não conseguiu obter consenso entre entidades participantes do seu acompanhamento.

Em dezembro de 1996, o CORHI deliberou a constituição de dois Grupos de Trabalho com técnicos da Secretaria do Meio Ambiente (SMA), Companhia Estadual de Saneamento Básico (CETESB) e Departamento de Águas e Energia Elétrica (DAEE), para fornecerem subsídios à implementação da cobrança pelo uso da água. Foram constituídos o Grupo de Trabalho do Modelo Jurídico-Institucional e o Grupo de Trabalho do Modelo de Simulação. (CORHI, 1997)

É interessante mencionar que esse estudo deu origem à proposta do projeto de lei para implantação da cobrança (PL 20/98), encaminhada à Assembléia Legislativa em dezembro de 1997. O modelo de simulação proposto considerava que a cobrança 
seria aplicada sobre a utilização das águas superficiais e subterrâneas dos seguintes segmentos: serviços de água e esgoto; indústrias com captações próprias; irrigantes; e outros, como geração hidrelétrica, abastecimento rural, lazer, recreação, aqüicultura, navegação. CORHI (1997)

O modelo propôs para todo o Estado uma tabela de "Preços Unitários Básicos" (PUB) para os seguintes usos das águas (TABELA 16): usos não consuntivos, usos consuntivos, diluição dos lançamentos de DBO (Demanda Bioquímica de Oxigênio), DQO (Demanda Química de Oxigênio), RS (Resíduo Sedimentável) e CI (Carga Inorgânica: Metais, Cianetos e Fluoretos).

TABELA 16 - Preços Unitários Básicos e Máximos.

\begin{tabular}{ccccc}
\hline Usos & Unidade & Símbolo & PUB (R\$) & Preço Unitário Máximo (R\$) \\
\hline Captação & $\mathrm{m}^{3}$ & PUB $_{\text {Cap }}$ & 0,01 & 0,05 \\
\hline Consumo & $\mathrm{m}^{3}$ & PUB $_{\text {Cons }}$ & 0,02 & 0,10 \\
\hline Lançamentos & & & & \\
- de DBO & $\mathrm{kg} \mathrm{DBO}$ & PUB $_{\mathrm{DBO}}$ & 0,10 & 1,00 \\
- de DQO & $\mathrm{kg} \mathrm{DQO}$ & PUB $_{\mathrm{DQO}}$ & 0,05 & 0,50 \\
- de RS & litro & PUB $_{\mathrm{RS}}$ & 0,01 & 0,10 \\
- de CI & $\mathrm{kg}$ & $\mathrm{PUB}_{\mathrm{CI}}$ & 1,00 & 10,00 \\
\hline
\end{tabular}

Fonte: Adaptado de CORHI (1997).

O “Preço Unitário Final” (PUF) da cobrança, para cada parâmetro, seria obtido pela multiplicação do "Preço Unitário Básico” por coeficientes multiplicadores que considerassem: natureza do manancial; classe do corpo de água; finalidade a que se destina; localização dos usuários na bacia; sazonalidade; e peculiaridades locais. O “Preço Unitário Final” para cada parâmetro, assim calculado, deveria ser menor que o “Preço Unitário Máximo” indicado na TABELA 16.

Desta maneira, o valor total da cobrança para determinado usuário seria a soma dos valores de cada parâmetro, limitado superiormente por um valor calculado como porcentagem do "Custo Médio Referencial de Produção Anual” ou do faturamento anual. Assim, a cobrança seria dada pela equação (11): 


$$
\text { Cobrança }=\sum_{j} \operatorname{PUB}_{j} \cdot \mathrm{Q}_{\mathrm{j}, \mathrm{i}} \cdot \mathrm{X}_{\mathrm{j} . \mathrm{i}}
$$

Onde:

Cobrança = Valor cobrado sobre captação, consumo, ou lançamento de efluentes $\mathrm{PUB}_{\mathrm{j}}=$ Preço unitário básico do uso $\mathrm{j}$

$\mathrm{Q}_{\mathrm{j}, \mathrm{i}}=$ Quantidade de água utilizada ou poluente lançado pelo o uso j na bacia i $\mathrm{X}_{\mathrm{j}, \mathrm{i}}=$ Coeficientes multiplicadores para o uso $\mathrm{j}$ na bacia $\mathrm{i}$

Percebe-se que a metodologia proposta procura considerar a escassez relativa por meio de coeficientes multiplicadores. Estes poderiam retratar o grau de saturação no qual se encontra a bacia, e assim estabelecer valores que levem em conta estas especificidades. Porém, é preciso que a aplicação dos coeficientes seja acompanhada de Preços Unitários Básicos (PUB) que realmente retratem o real valor da água, caso contrário, a cobrança poderá não fornecer incentivos à racionalização do uso da água.

Para esta proposta, é relevante a preocupação anteriormente mencionada, pois os PUB tiveram como referência o sistema francês de cobrança. Portanto, a adoção desses números, por parte da proposta de São Paulo, poderá não ser indutor de conduta racional em relação à utilização dos recursos hídricos, como também não ocorre na França. Entretanto, é preciso esperar os resultados de sua aplicação, uma vez que a realidade francesa é distinta da realidade brasileira.

SEROA DA MOTTA (1998) comenta que a forma proposta para cobrança no Estado de São Paulo utiliza como critério distributivo a capacidade de pagamento. Para o autor, esta solução parece ter sido resultante do processo de negociação entre os interesses setoriais e, certamente, o sistema paulista aponta para um mecanismo de geração de receita, sem qualquer motivação para induzir a racionalização de uso por preços ótimos ou eficientes.

Atualmente, a aplicação da cobrança no Estado de São Paulo ainda depende da aprovação do PL 676/00.

Esse sistema de cobrança proposto estará diretamente atrelado à existência anterior dos Planos de Recursos Hídricos, previamente aprovados pelos respectivos Comitês de Bacia e pelo Conselho Estadual de Recursos Hídricos (CRH) (art. $2^{\circ}$ ). 
O PL 676/00 prevê a implantação gradativa da cobrança, com participação dos Comitês e organização do cadastro específico de usuários; além disso, existe a possibilidade da Assembléia Legislativa - de forma direta e complementar - exercer a fiscalização em relação à aplicação dos recursos da cobrança por parte dos Comitês de Bacia. (art. $3^{\circ}$ e art. $4^{\circ}$ )

$\mathrm{O}$ artigo $5^{\circ}$ estabelece que estão sujeitos à Cobrança todos aqueles que utilizam recursos hídricos - excetuando-se a utilização destinada às necessidades domésticas de pequenos núcleos populacionais em zonas rurais e nos casos de usos inferiores a 10 m³/mês. Em cada bacia, caberá à entidade responsável pela outorga a aplicação da cobrança enquanto a referida bacia ainda estiver desprovida de Agência. (art. $7^{\circ}$ )

Entre os artigos incluídos no PL 676 de 2000, o (art. 12º) apresenta grande controvérsia. Este artigo fixa em $\mathrm{R} \$ 0,01 / \mathrm{m}^{3}$ o valor máximo a ser cobrado nos casos de captação, extração, derivação e consumo, sem que haja a mesma amarração nos casos de diluição, transporte e assimilação de efluentes, que são objeto dos artigos $13^{\circ}$ ao $15^{\circ}$. Percebe-se que este condicionante (valor limite de $\mathrm{R} \$ 0,01 / \mathrm{m}^{3}$ para os casos de captação, extração, derivação e consumo) poderá comprometer a cobrança como instrumento econômico de gestão.

\subsection{Considerações dos casos nacionais}

As experiências do Brasil, no uso dos instrumentos econômicos de gestão dos recursos hídricos, são dotadas de caráter incipiente. Assim, a implantação dos instrumentos econômicos dentro da política de recursos hídricos e seus resultados, ainda não oferecem subsídios para precisa avaliação em relação à melhoria na qualidade ambiental. Entretanto, vale ressaltar que nos casos aqui analisados existe tendência a se seguir as experiências internacionais, as quais, no caso específico da cobrança, deixam a desejar no que concerne ao reconhecimento da escassez relativa como preceito de um sistema cuja finalidade deve ser racionalizar o uso da água.

Na análise da experiência do Estado do Ceará é evidente a pouca preocupação do Estado em transformar a cobrança em instrumento de gestão e estimulo ao uso racional dos seus recursos hídricos. O Ceará, por possuir severa escassez de água, deveria usar a cobrança para garantir acesso à água em boa quantidade e qualidade. 
Além disso, é notória a necessidade de se conciliar a gestão do uso do solo com gestão da água, pois nem sempre onde existe “solo” existe água e vice-versa. Assim, o produto da cobrança poderia ajudar no alcance desse objetivo. O modelo proposto por ARAÚJO (1996) reconhece a necessidade da gestão integrada entre o solo e a água, porém, como o próprio autor afirma, é preciso alguns ajustes para aplicá-lo, como por exemplo: considerar a sazonalidade na estimação do consumo de água para irrigação; avaliar os custos da água baseados em investimentos futuros, custos de operação, manutenção e gerenciamento; considerar a capacidade de pagamento das populações atingidas pela cobrança.

A experiência do Estado de São Paulo em gestão das águas, em termos legais, possui caráter pioneiro. Entretanto, as práticas de gestão ainda não são integradas, ou seja, há diferentes instâncias administrativas responsáveis por parte da gestão das águas, porém, elas não “conversam” entre si. A pendência da aprovação do sistema de cobrança sobre usos da água é um retrato dos interesses corporativistas atuantes no Estado de São Paulo. Este tipo de atuação tem limitado, inclusive, a participação da sociedade nos Comitês de Bacia do Estado.

Em relação ao sistema de cobrança proposto para o Estado de São Paulo, cabe observar que ele considera, em sua formulação, alguns preceitos de escassez relativa. É o caso da aplicação dos coeficientes multiplicadores, cujo emprego possibilitaria estabelecer valores diferenciados de acordo com especificidades locais. Todavia, o sistema peca ao estabelecer um valor limite máximo para cobrança sobre captação, o qual em muitas situações não retrata a escassez verificada. Desta maneira, o sistema tende a se transformar em um procedimento de respeito a regras que, neste caso, é o pagamento da cobrança, pois o valor cobrado é “tabelado" e poderá não induzir à mudança no comportamento dos usuários. 


\section{Materiais e Métodos}

Com base nas formas e sistemas de cobrança sobre usos da água, analisados por meio da clássica revisão bibliográfica; para a aplicação de estudo de caso, adota-se o sistema de cobrança proposto e desenvolvido por SOUZA (1995).

\subsection{Cobrança}

Essa metodologia leva em conta a cobrança sobre lançamento de efluentes (considerada a carga de poluição) e sobre consumo de água.

A escolha dessa metodologia parte do princípio que o uso da água deve estar associado diretamente à manutenção de sua qualidade e ao uso do solo da bacia, portanto, comprometido com a qualidade ambiental desejada pela sociedade. Neste contexto, enquadra-se bem a metodologia utilizada, porque considera as questões acima expostas e, fundamentalmente, as especificidades ambientais locais.

O princípio essencial que rege essa metodologia é o da escassez relativa. Esse preceito é traduzido pelo estado de saturação do corpo de água, ou seja, na menor ou maior capacidade de atender ao serviço ambiental requerido. Assim, no ponto de aplicação do instrumento, a formulação considera a qualidade ambiental desejada, por meio do padrão de qualidade. Como a intenção da aplicabilidade da cobrança é a gestão, acredita-se que, em função da dimensão da escassez e da qualidade almejada para o corpo de água, essa metodologia poderá funcionar como mecanismo capaz de regular a apropriação dos recursos hídricos e ordenamento de uso do solo.

Desta maneira, essa metodologia procura resolver as causas dos problemas que geram escassez dos recursos hídricos. Portanto, neste caso, a cobrança sobre usos da água atua como instrumento de gestão que, atrelado a outros instrumentos, poderá compor um sistema de gestão, cuja arrecadação deverá ser conseqüência de sua aplicação e não seu objetivo. 


\subsubsection{Cobrança sobre lançamento de efluentes}

Esta metodologia parte da definição do padrão de qualidade do corpo de água receptor e dos usos dos recursos hídricos; a partir desses aspectos define-se a vazão mínima destinada à diluição e depuração de efluentes $(\mathrm{Q})$ e a concentração máxima possível de um parâmetro de poluição (padrão de qualidade do corpo de água), (c). Com essas duas variáveis pode-se calcular a carga de saturação (equação 12) relativa a um parâmetro de poluição de determinado corpo hídrico. Assim:

$$
\mathrm{Cs}=\mathrm{Q} \cdot \mathrm{c}
$$

Onde:

Cs = Carga de saturação do corpo de água (mg/s);

$\mathrm{Q}$ = Vazão do corpo receptor, destinada à diluição e depuração de efluentes (L/s);

c = Concentração máxima permitida para determinado parâmetro (mg/L).

Uma vez calculada a carga de saturação, consideram-se todas as atividades em cujos efluentes sejam encontrados os parâmetros passíveis de cobrança. Esses usos contribuem com a carga de poluição remanescente (Ce), interpretada como o produto entre a vazão e a concentração do parâmetro poluidor contido no efluente. A partir de então, define-se o índice de carga (Ic) (equação 13):

$$
\text { Ic }=\left(\mathrm{Cs}-\sum \mathrm{Ce}\right) / \mathrm{Cs}
$$

Onde:

Ic $=$ Índice de carga

Cs = Carga de saturação do corpo de água (mg/s)

$\sum \mathrm{Ce}=$ Somatório das cargas poluidoras remanescentes, emitidas no corpo receptor a montante do ponto de lançamento, considerando a sua depuração (mg/s)

É importante destacar que, de maneira isolada, o índice de carga (Ic) expressa o nível de comprometimento da qualidade do corpo d’água receptor, com relação a um determinado parâmetro de poluição. Este índice garante a ponderação da capacidade 
de suporte do recurso hídrico, uma vez que todas as atividades estão contempladas, e a vazão mínima para depuração devidamente incorporada ao índice especificado.

A relação entre o índice de carga e o valor cobrado é feita por meio da equação definida a partir do custo médio de sistemas de tratamento de efluentes (método de valoração denominado custos de controle). Neste sentido, define-se um multiplicador (Kc) para cada poluente a ser cobrado, o que permite o cálculo do valor da cobrança para cada atividade. Neste trabalho o (Kc) é expresso em (US\$/mês)/(L/s).

Alguns fatores são essenciais na consideração da cobrança sobre lançamento de efluentes. Dentre eles destacam-se: a sazonalidade, ou seja, época do lançamento, entre outras - estação de seca ou de chuva, porque a disponibilidade de água pode influenciar, significativamente, o valor a ser cobrado; uso associado ao lançamento, algumas atividades podem ser estimuladas em detrimento de outras - segundo as necessidades sociais envolvidas poderá haver cobrança diferenciada por atividade; outro fator a ser ponderado é a eficiência na alocação de recursos financeiros para o tratamento de efluentes. Há determinados sistemas que possuem maior eficiência na eliminação de um mesmo poluente, assim, devem ser estimulados - observando que deve ser sempre removida a quantidade mínima estabelecida pela legislação, a fim de atender o padrão de emissão.

Define-se o fator de ponderação (U) (fator ponderador para a cobrança sobre lançamento de efluentes), com a finalidade de expressar a sazonalidade, diferentes atividades e eficiência na alocação de recursos financeiros. O valor deste ponderador é determinado pela gestão da bacia e nunca menor do que 1 (um).

Para incentivar usuários os quais conseguem que as concentrações de poluentes em seus lançamentos sejam menores que aquelas indicadas no padrão de emissão, e para penalizar os que lançam em concentrações acima dos limites - utiliza-se a razão (ce/cp), onde (ce) é a concentração do poluente no efluente, e (cp) é a concentração máxima do poluente estipulada pelo padrão de emissão. Portanto, o valor a ser pago (Te) sobre lançamento de carga de poluição é (equação 14):

$$
\mathrm{Te}=\mathrm{Kc} \cdot \mathrm{Qe} \cdot \mathrm{U} \cdot \text { (ce/cp) }
$$

Onde:

Te = Cobrança sobre lançamento de efluentes (US\$/mês) 
Kc = Coeficiente multiplicador (US\$/mês)/(L/s)

$\mathrm{Qe}=$ Vazão do efluente final $(\mathrm{L} / \mathrm{s})$

$\mathrm{U}=$ Fator ponderador da sazonalidade, do tipo de usuário e da eficiência econômica

do tratamento, para o caso de lançamento de efluentes

ce $=$ Concentração do poluente no efluente final $(\mathrm{mg} / \mathrm{L})$

cp = Concentração máxima permitida pelo padrão de emissão (mg/L)

O valor total cobrado é o somatório dos valores calculados para cada poluente, de cada apropriador que lance efluentes no corpo receptor.

\subsubsection{Cobrança sobre consumo de água}

A cobrança sobre captação considera apenas a quantidade de água efetivamente consumida; isto é, deve-se descontar da vazão extraída a quantidade devolvida na forma de efluentes (observando que os efluentes são lançados em águas superficiais). A consideração a respeito da cobrança sobre consumo de água, parte do pressuposto que a vazão captada líquida afeta a capacidade de depuração e diluição do corpo de água. Assim, o autor relaciona o consumo de água com a pior situação de poluição encontrada no corpo de água; isto é, considera-se o parâmetro poluente que apresenta situação mais próxima à saturação.

Sempre que existir captação líquida, haverá queda na capacidade assimilativa do corpo hídrico. Como essa queda é proporcional à vazão captada, consideram-se os momentos: imediatamente anterior e posterior à captação superficial. Na situação anterior à captação o coeficiente multiplicador $\left(\mathrm{K}_{1}\right)$ é função de $\left(\mathrm{I}_{1}\right)$, sendo $\left(\mathrm{I}_{1}\right)$ o índice de carga do corpo de água, portanto (equação 15):

$$
\mathrm{I}_{1}=(\mathrm{Cs}-\Sigma \mathrm{Ce}) / \mathrm{Cs}
$$

Para o cálculo de ( $\left.\mathrm{I}_{2}\right)$, situação imediatamente posterior à captação, associa-se à vazão consumida a queda na capacidade de depuração e diluição do corpo receptor. Portanto, a vazão destinada a esses serviços ambientais sofre uma redução de (Qcon). Então, $\left(\mathrm{I}_{2}\right)$ é calculado pela seguinte expressão (equação 16): 


$$
\mathrm{I}_{2}=\left[(\mathrm{Q}-\mathrm{Qcon}) . c-\sum \mathrm{Qe} . c e\right] /[(\mathrm{Q}-\mathrm{Q} \text { con }) . c]
$$

Para o cálculo de $\left(\mathrm{K}_{1}\right)$ e $\left(\mathrm{K}_{2}\right)$ são utilizadas as mesmas expressões de cálculo do $(\mathrm{Kc})$, para o caso de lançamento de efluentes.

Para o cálculo do valor da cobrança sobre a captação de água superficial (Tc), é necessária a comparação entre a situação anterior e a posterior à captação superficial, realizada por meio da subtração dos coeficientes multiplicadores $\left(\mathrm{K}_{1}\right)$ e $\left(\mathrm{K}_{2}\right)$. Assim, a cobrança sobre consumo de água é dada pela equação (17).

$$
\mathrm{Tc}=\left(\mathrm{K}_{2}-\mathrm{K}_{1}\right) \cdot \mathrm{S} \cdot \sum \mathrm{Qe} \cdot \mathrm{ce} / \mathrm{cp}
$$

Onde:

Tc = Cobrança sobre consumo de água (US\$/mês)

$\mathrm{K}_{2}=$ Coeficiente multiplicador da situação posterior à captação (US\$/mês)/(L/s)

$\mathrm{K}_{1}=$ Coeficiente multiplicador da situação anterior à captação (US\$/mês)/(L/s)

$\mathrm{S}=$ Fator ponderador da sazonalidade e do tipo de atividade

Qe = Vazão do efluente final de cada emissão à montante da captação (L/s)

ce = Concentração do poluente no efluente final de cada emissão (mg/L)

cp = Concentração máxima permitida pelo padrão de emissão (mg/L)

Cabe observar que no somatório expresso pela equação (17) deve-se considerar o comportamento dos poluentes (conservativos ou não conservativos), para que seja adotada a real carga poluidora remanescente que existe em uma seção de estudo específica. Para contornar a falta de informações concernentes à autodepuração no trecho de corpo hídrico, no qual a metodologia de cobrança foi aplicada, optou-se por arbitrar uma taxa de depuração que incide no somatório das cargas remanescentes a montante da seção em estudo.

Para traçar as curvas de custo dos sistemas de tratamento de efluentes, SOUZA (1995) utiliza a publicação de Vernick e Walter de 1981, com atualizações feitas por meio da Engineering News Record (ENR). A partir dos dados encontrados nesta bibliografia e da análise de regressão efetuada, foram obtidas curvas de melhor comportamento para expressar os custos totais (TABELA 17). 
TABELA 17 - Curvas de custos totais de sistemas de tratamento de efluentes.

\begin{tabular}{c|c|c}
\hline Lagoa anaeróbia & Lagoa facultativa & Sistemas de desnitrificação \\
\hline $\mathrm{y}=7,12 \cdot 10^{-5} \cdot \mathrm{x}^{0,694644}$ & $\mathrm{y}=1,31 \cdot 10^{-4} \cdot \mathrm{x}^{0,673418}$ & $\mathrm{y}=1,17 \cdot 10^{-3} \cdot \mathrm{x}^{0,649126}$ \\
\hline
\end{tabular}

Onde: $\mathrm{x}=$ Vazão do efluente $\left(\mathrm{m}^{3} / \mathrm{dia}\right) ; \mathrm{y}=$ Custos totais $\left(10^{6} . \mathrm{US} \$ / \mathrm{ano}\right)$

Para a construção das curvas dos coeficientes multiplicadores (K) translada-se a curva de custos totais de forma a atender às seguintes condições: impor que a curva de cobrança corte o eixo das abscissas no ponto 1 (um), ou seja, para $y=0, x=1$; inverter a curva, isto é, os valores das ordenadas devem crescer à medida que os valores das abscissas se tornem menores, portanto, $\mathrm{x}=1-\mathrm{x}$; ajustar as unidades ( $\mathrm{m}^{3}$ /dia em L/s, milhões de dólares em dólares, e ano em mês); e adotar o coeficiente multiplicador (K) no eixo das ordenadas e o valor de (I) no eixo das abscissas. A TABELA 18 apresenta os coeficientes multiplicadores.

TABELA 18 - Coeficientes multiplicadores de acordo com o tipo de tratamento.

\begin{tabular}{c|c|c}
\hline Lagoa anaeróbia & Lagoa facultativa & Sistema de desnitrificação \\
\hline $\mathrm{K}=5,13 \cdot 10^{2} \cdot(1-\mathrm{I})^{0,69}$ & $\mathrm{~K}=9,42 \cdot 10^{2} \cdot(1-\mathrm{I})^{0,67}$ & $\mathrm{~K}=8,42 \cdot 10^{3} \cdot(1-\mathrm{I})^{0,65}$ \\
\hline
\end{tabular}

Onde: $\mathrm{K}$ em (US\$/mês)/(L/s); I = Índice de carga

O critério adotado para a escolha do $(\mathrm{K})$ relacionado aos sistemas de tratamento é o seguinte: para (I) variando entre 1 e 0,02, o custo associado é o de uma lagoa anaeróbia, ou do tratamento primário, se houver informações; para (I) variando entre 0,02 e 0, o custo associado é de uma lagoa facultativa, ou de tratamento secundário; e para valores menores do que 0 , o custo associado é de um sistema de desnitrificação, ou de tratamento terciário, caso haja disponibilidade de informações.

A metodologia de cobrança adotada preconiza o custo médio do tratamento de efluentes na ponderação do valor econômico da água. Vale ressaltar, porém, que este não é um método fechado; portanto, pode ser usado outro método de valoração. 


\section{Estudo de Caso: reservatório de Salto Grande (Americana, SP)}

\subsection{Bacia do rio Atibaia e o reservatório de Salto Grande}

Antes da aplicação da metodologia de cobrança, procurou-se contextualizar a área de estudo frente às suas características físicas, ambientais e sócio-econômicas.

O reservatório de Salto Grande está localizado no município de Americana, SP. Ele é formado pelo represamento do rio Atibaia, portanto, pertence a uma sub-bacia da bacia hidrográfica do rio Piracicaba, a qual, em conjunto com as bacias dos rios Capivari e Jundiaí, forma a 5a Unidade de Gerenciamento de Recursos Hídricos (UGRHI) do Estado de São Paulo.

A bacia do rio Piracicaba localiza-se em uma das regiões de maior crescimento econômico do país ( $3^{\circ}$ pólo industrial do Brasil, atrás da Região Metropolitana de São Paulo (RMSP) e do Rio de Janeiro). A origem desse crescimento foi a política de desenvolvimento adotada nos anos 70 que incentivou o deslocamento de parte das atividades industriais e agroindustriais da Região Metropolitana de São Paulo para o interior do Estado - notadamente para a referida bacia. Assim, alguns municípios especialmente da região de Campinas, passaram a constituir pólos de atração de diversas atividades consumidoras e degradadoras dos recursos hídricos.

O estilo de desenvolvimento adotado na região acarretou um alto índice de urbanização (93,5\% para a bacia do Piracicaba em 2000). Nesta bacia, a disputa pela água permanece crescendo, além disso, são verificados alguns processos de saturação quantitativa e qualitativa dos recursos hídricos.

De acordo com COPLAENGE (2000), a bacia do rio Atibaia é a mais crítica em termos de demanda/disponibilidade. Em 2000, considerada a vazão Q7,10 (vazão mínima anual de sete dias consecutivos e período de retorno de 10 anos), a demanda nessa bacia atingiu 139,5\% da oferta, já em relação à vazão Q95 (vazão mínima anual com 95\% de permanência) a demanda atingiu 106\% da disponibilidade. 
A bacia do rio Atibaia localiza-se no centro leste do Estado de São Paulo, entre os paralelos $22^{\circ} 41^{\prime}$ e $23^{\circ} 18^{\prime}$ ao sul e os meridianos $46^{\circ} 00^{\prime}$ e $47^{\circ} 16^{\prime}$ a oeste; sua área de drenagem é cerca de $2.820 \mathrm{~km}^{2}$, e vai da divisa com Minas Gerais até o rio Piracicaba. Nessa bacia, a população estimada para o ano de 2002 é cerca de 910 mil habitantes (48\% da área do município de Campinas encontra-se nessa bacia), deste total, 94\% residem em zonas urbanizadas. Entre os municípios presentes nessa bacia destacam-se: Campinas, Americana, Paulínia e Atibaia.

Pertencente à bacia do rio Atibaia, o reservatório de Salto Grande possui como coordenadas: Latitude Sul de $22^{\circ} 44^{\prime}$ e Longitude Oeste de $44^{\circ} 19^{\prime}$. A represa está a altitude de aproximadamente 540 m em relação ao nível do mar. Data de 1950, o início de sua operação, cuja finalidade primordial era a geração de energia elétrica.

O rio Atibaia é a única drenagem significativa que alimenta o reservatório, cuja barragem está cerca de $850 \mathrm{~m}$ a montante da confluência do rio Atibaia com o rio Jaguari - formadores do rio Piracicaba. Encontra-se, instalada na represa, a Usina Hidrelétrica de Americana, de propriedade da CPFL - Geração de Energia S.A., com capacidade de geração de 30 MW. A TABELA 19 apresenta algumas características do reservatório de Salto Grande.

TABELA 19 - Características do reservatório de Salto Grande.

\begin{tabular}{l|c}
\hline \multicolumn{1}{c|}{ Reservatório } & Medida \\
\hline Área da bacia hidráulica & $11,5 \mathrm{~km}^{2}$ \\
Perímetro & $64 \mathrm{~km}$ \\
Comprimento & $17 \mathrm{~km}$ \\
Nível máximo operativo & $501,30 \mathrm{~m}$ \\
Volume máximo operativo & $106,7.10^{6} \mathrm{~m}^{3}$ \\
Nível mínimo operativo & $500,28 \mathrm{~m}$ \\
Volume mínimo operativo & $93,6.10^{6} \mathrm{~m}^{3}$ \\
Nível médio operativo & $501,00 \mathrm{~m}$ \\
Profundidade máxima & $19 \mathrm{~m}$ \\
Profundidade média & $9 \mathrm{~m}$ \\
\hline
\end{tabular}

Fonte: FERREIRA (2000). 
Baseado na classificação climática de Köppen, a bacia do rio Atibaia apresenta, no seu trecho superior, clima temperado brando sem estação seca e com verão suave - tipo CFb. Nesse trecho, a temperatura média anual é de $18^{\circ} \mathrm{C}$. Nos trechos médio e inferior - onde está o reservatório de Salto Grande, o clima é temperado brando com inverno seco e verão quente - tipo Cwa, com temperatura média anual de $20^{\circ} \mathrm{C}$. No trecho superior são registrados os maiores valores de precipitação (1500 mm/ano); no trecho inferior os menores valores (1200 mm/ano). Os meses de dezembro, janeiro e fevereiro são os mais quentes e chuvosos; por sua vez, os meses de junho, julho e agosto são os mais frios e secos. (FERREIRA, 2000)

A represa está na bacia sedimentar do Paraná. Apresenta rochas sedimentares paleozóicas representadas pelo grupo Tubarão - formação Itararé (CPi), as quais são formadas por arenitos de granulação variada, imaturos passando a arcósios, além de conglomerados e sedimentos mais finos representados por siltitos, folhelhos, ritmitos e tilitos que repousam sobre as superfícies erosivas entalhadas em rochas cristalinas eopaleozóicas e pré-cambrianas. As litologias da formação Itararé são constituídas, quase inteiramente, por sedimentos clásticos, embora possam ocorrer finas camadas de carvão e calcário em locais específicos. (CETEC, 2000)

As águas da represa cobrem uma área da Depressão Periférica Paulista que se encontra embutida entre as Cuestas e o Planalto Atlântico, e apresenta topografia predominantemente colinosa. Em volta do reservatório ocorre relevo de degradação em planaltos dissecados, formado por colinas amplas onde predominam declividades até $15 \%$; amplitudes locais inferiores a $100 \mathrm{~m}$; interflúvios com área superior a 4 $\mathrm{km}^{2}$; topos extensos e aplainados; vertentes com perfis retilíneos a convexos; vales abertos a fechados; baixa densidade de drenagem; e planícies aluviais interiores restritas. (CETEC, 2000)

Os solos encontrados no entorno da represa são diferenciados de acordo com a margem. À margem direita, no início da bacia hidráulica, encontra-se o Podzólico Vermelho-Amarelo, seguido de Terra Roxa Estruturada, uma pequena faixa de solos Litólicos, uma grande área de Latossolo Vermelho-Amarelo e, próximo à barragem, novamente Terra Roxa Estruturada. Na margem esquerda predomina o Podzólico Vermelho-Amarelo com pequenas faixas de Terra Roxa Estruturada e Latossolo Vermelho-Escuro. (LEITE, 1998) 
A água de Salto Grande é aproveitada para usos múltiplos. Além da geração de energia elétrica, são verificados outros usos: captações para agropecuária, aqüicultura e abastecimento urbano; recreação/lazer e disposição de efluentes líquidos de origem doméstica. Segundo RIOS (1999), esse reservatório também funciona como grande sistema de tratamento de efluentes, e contribui para a melhoria da qualidade da água do rio Atibaia a jusante do reservatório. O autor encontrou eficiências de retenção de 88\% do material particulado total; 91\% do material particulado inorgânico; 73\% do material particulado orgânico; $76 \%$ do fósforo total; 69\% do fosfato total dissolvido; $86 \%$ do fosfato inorgânico dissolvido e $71 \%$ de ferro total.

A grande ocupação urbana e industrial na bacia do rio Atibaia é fonte principal de poluentes. Essa bacia serve de manancial abastecedor para 16 municípios e recebe seus efluentes domésticos e industriais (cerca de 48,51 tDBO/dia). O ponto que reúne grande parte desses poluentes é a represa de Salto Grande, que apresenta um quadro de extrema degradação - confirmado pelos estudos de LEITE (1998), RIOS (1999), TEIXEIRA (2000) e FERREIRA (2000).

A TABELA 20 apresenta o quadro geral de uso e ocupação do solo na bacia do rio Atibaia. Percebe-se que em áreas não urbanizadas predominam as pastagens e os campos antrópicos, com cerca de 71,5\% da área da bacia. As culturas predominantes são: milho, cana-de-açúcar, café, uva e laranja; às coberturas vegetais naturais correspondem matas formadas por floresta ombrófila densa, estacional semidecidual, capoeiras, cerrados e vegetação natural de várzea. Os reflorestamentos, por sua vez, são constituídos predominantemente por eucaliptos e pinus; nas pastagens cultivadas ocorre o predomínio da braquiária.

No entorno do reservatório, o uso e ocupação do solo é diferenciado de acordo com as margens. Na margem direita predomina a cultura da cana-de-açúcar, algumas faixas de culturas anuais, capoeira, citrus e mata natural. À margem esquerda são encontrados campos antrópicos, representados por chácaras de veraneio, clubes e áreas de lazer públicas e urbanizadas - consideradas bairros da cidade de Americana (RIOS, 1999). Outras ocupações encontradas nessa margem são pastagens e culturas de citrus e café. 
TABELA 20 - Uso e ocupação do solo na bacia do rio Atibaia.

\begin{tabular}{lcc}
\multicolumn{1}{c}{ Usos e Ocupações } & Área $\left(\mathrm{km}^{2}\right)$ & Porcentagem (\%) \\
\hline Culturas Temporárias & 117,26 & 4,2 \\
Culturas Perenes & 68,91 & 2,4 \\
Cobertura Vegetal Natural & 342,95 & 12,2 \\
Reflorestamentos & 123,93 & 4,4 \\
Pastagens e Campos Antrópicos & $2.017,55$ & 71,5 \\
Áreas Urbanas e Industriais & 149,80 & 5,3 \\
Área Total & $2.820,40$ & 100 \\
\hline
\end{tabular}

Fonte: Baseada em dados de COPLAENGE (2000).

Na FIGURA 2 é apresentada a localização da $5^{\text {a }}$ UGRHI que compreende as bacias dos rios Piracicaba, Capivari e Jundiaí. Na FIGURA 3 é mostrada com detalhe a bacia do rio Atibaia.

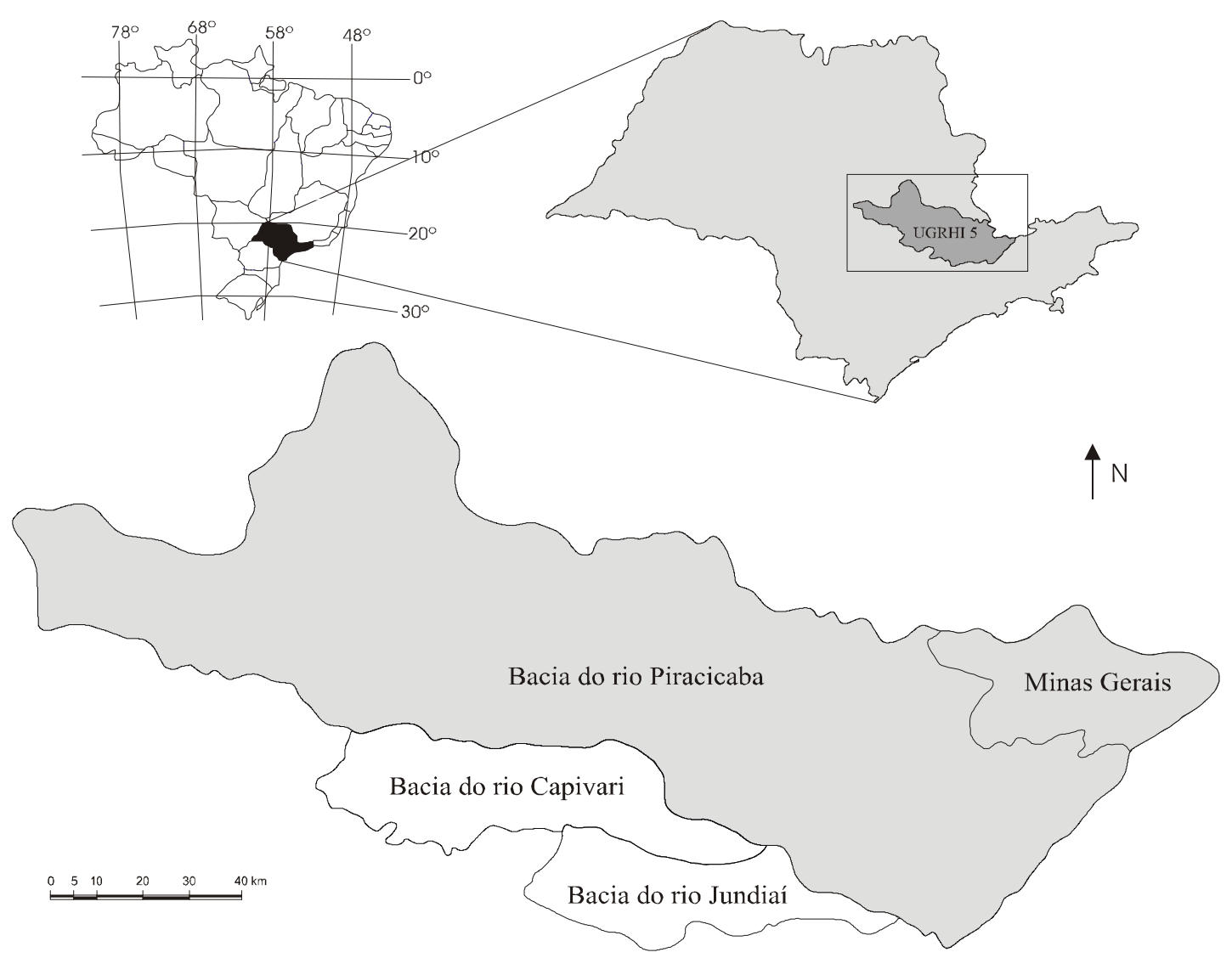

FIGURA 2 - Bacias hidrográficas componentes da $5{ }^{\mathrm{a}}$ UGRHI. 


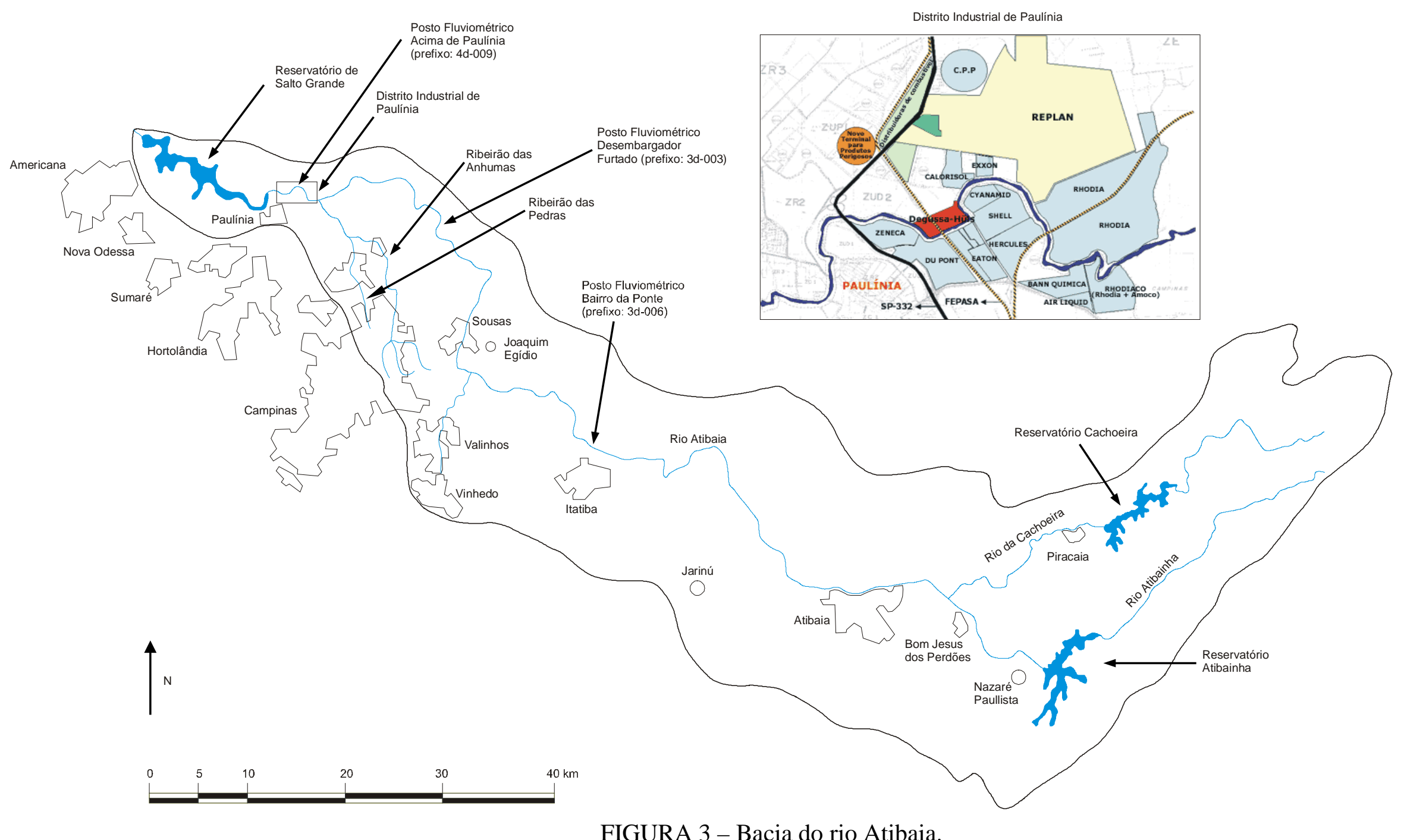




\subsection{Aplicação da cobrança sobre usos da água no reservatório de Salto Grande}

Este capítulo tem como objetivo o exercício da aplicação da metodologia de cobrança - desenvolvida por SOUZA (1995) - sobre usos da água no reservatório de Salto Grande. Nessa aplicação não foram considerados usos como recreação/lazer e aqüicultura, portanto, ela ficou restrita a usos como: captação para abastecimento urbano, captação do setor agropecuário, lançamento de efluentes líquidos de origem doméstica e geração de energia.

Na aplicação da metodologia e na discussão dos resultados foi considerado o quadro de elevada escassez apresentado por esse corpo de água. Neste contexto, o emprego dos instrumentos econômicos de gestão dos recursos hídricos pode fornecer incentivos ao uso racional das águas e amenizar possíveis conflitos. Ressalta-se que a cobrança é um instrumento econômico cuja atuação no ordenamento de uso do solo pode ter importância relevante, principalmente, em regiões que apresentam elevado grau de saturação em relação ao uso da água.

\subsubsection{Cenário de vazões}

A vazão média mensal (Qmed,mês) foi adotada para aplicação da metodologia. O cálculo dessas vazões considerou a série histórica do posto fluviométrico Acima de Paulínia (prefixo 4D-009) da CPFL - Geração de Energia S.A., localizado no rio Atibaia na Latitude de $22^{\circ} 44^{\prime}$ 38' ' S e Longitude de $47^{\circ} 07^{\prime} 47^{\prime \prime}$ O. Este fluviômetro está a jusante da confluência do ribeirão Anhumas com o rio Atibaia (FIGURA 3), portanto, retrata bem as vazões que adentram o reservatório de Salto Grande.

Devido à reversão de $31 \mathrm{~m}^{3} / \mathrm{s}$ da bacia do rio Piracicaba para o abastecimento da Região Metropolitana de São Paulo (RMPS) - por meio do Sistema Cantareira, as séries temporais de vazões dos rios Atibaia, Jaguari e Piracicaba têm sofrido os efeitos desta transposição interbacias. MORAES et al. (1997) realizaram análise exploratória das séries históricas de vazões desses rios, e constataram a influência da construção das barragens do Sistema Cantareira no decréscimo das vazões a jusante deste sistema. 
No caso do rio Atibaia os efeitos foram detectados a partir de 1975 e ficaram mais patentes quando do início da reversão interbacias, nesse rio, em 1976. Este fato justifica a opção em adotar a série de vazões a partir 1975, estendendo-a até 1996 (último ano de dados disponíveis), a fim de tornar as simulações de cobrança mais próximas à realidade. Cabe observar que os meses com falha foram completados por meio de regressões lineares. Para efetuar essas regressões foram utilizadas as séries históricas dos postos: Desembargador Furtado (prefixo 3D-003) e Bairro da Ponte (prefixo 3D-006), ambos de propriedade do DAEE e localizados no rio Atibaia a montante do posto Acima de Paulínia. A TABELA 21 e FIGURA 4 apresentam as vazões médias mensais afluentes ao reservatório de Salto Grande.

TABELA 21 - Vazões médias mensais afluentes ao reservatório de Salto Grande.

\begin{tabular}{c|cccccccccccc}
\hline Mês & Jan & Fev & Mar & Abr & Mai & Jun & Jul & Ago & Set & Out & Nov & Dez \\
\hline Qmed (m³/s) & 55,5 & 52,8 & 50,3 & 36,5 & 31,4 & 33,5 & 26,6 & 21,5 & 26,9 & 30,2 & 33,0 & 43,9 \\
\hline
\end{tabular}

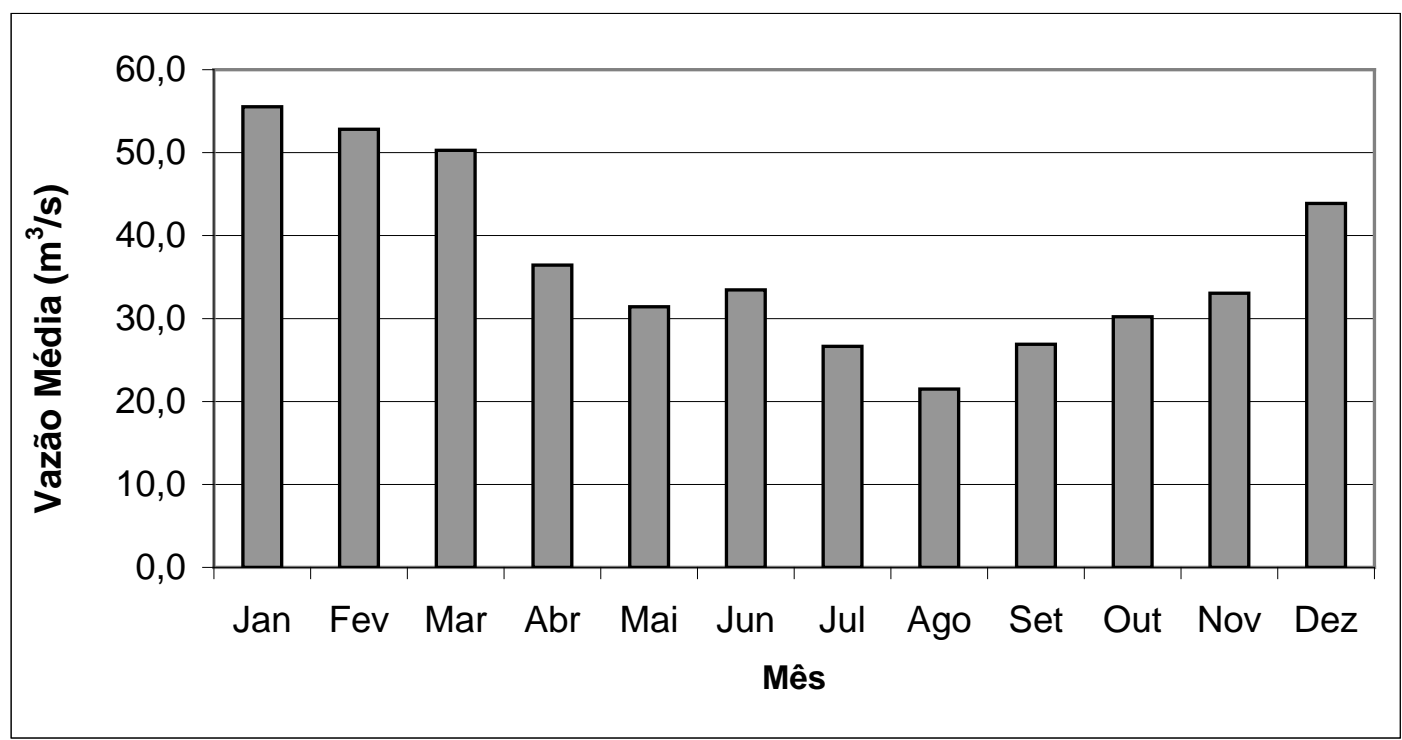

FIGURA 4 - Gráfico de vazões médias mensais afluentes ao reservatório de Salto Grande.

O regime de vazões a jusante do Sistema Cantareira tem sofrido influência da operação dos reservatórios nas cabeceiras dos rios Atibainha e Cachoeira (bacia do Atibaia) e dos rios Jacareí/Jaguari (bacia do Jaguari). Na bacia do rio Atibaia, a área 
de drenagem desses reservatórios $\left(715 \mathrm{~km}^{2}\right)$ - pertencente ao Sistema Cantareira corresponde a cerca de $25,3 \%$ da área de drenagem de toda a bacia $\left(2.820 \mathrm{~km}^{2}\right.$ ); aí ocorrem os maiores índices pluviométricos de precipitação. Portanto, boa parte do volume de água drenado pela bacia do Atibaia fica retido no Sistema Cantareira, que apenas contribui para o rio Atibaia a vazão regularizada média de $8,2 \mathrm{~m}^{3} / \mathrm{s}$.

As vazões do rio Atibaia são influenciadas por outras reversões além daquela anteriormente mencionada. É o caso das exportações do rio Atibaia para o rio Jundiaí Mirim (bacia do rio Jundiaí), para abastecimento do município de Jundiaí, e da bacia do Atibaia para as bacias dos rios Capivari e Piracicaba, por meio do sistema de abastecimento de água de Campinas. É o caso, ainda, da importação da bacia do rio Jaguari para a bacia do rio Atibaia.

Portanto, na bacia do rio Atibaia, a disponibilidade hídrica superficial resulta do balanço entre vazões naturais dos trechos a jusante do Sistema Cantareira; vazão liberada por esse sistema; vazões exportadas e provenientes de importações. Para se obter uma idéia da grandeza dessas vazões, a TABELA 22 apresenta o quadro geral da disponibilidade hídrica superficial na bacia do Atibaia para vazões de referência $\mathrm{Q}_{7,10}$ e $\mathrm{Q}_{95}$.

TABELA 22 - Disponibilidade hídrica superficial na bacia do rio Atibaia.

\begin{tabular}{l|cc}
\hline \multicolumn{1}{c|}{ Bacia do rio Atibaia } & $\mathrm{Q}_{7,10}\left(\mathrm{~m}^{3} / \mathrm{s}\right)$ & $\mathrm{Q}_{95}\left(\mathrm{~m}^{3} / \mathrm{s}\right)$ \\
\hline Vazão natural a jusante do Sistema Cantareira & 7,32 & 11,01 \\
Vazão regularizada pelo Sistema Cantareira & 3,00 & 3,00 \\
Somatório das vazões importadas & 1,17 & 1,17 \\
Somatório das vazões exportadas & 2,31 & 2,31 \\
Vazão Total & 9,18 & 12,87 \\
\hline
\end{tabular}

Fonte: Baseada em dados de COPLAENGE (2000).

\subsubsection{Cenário de cargas poluidoras}

A jusante do Sistema Cantareira o rio Atibaia está enquadrado na Classe 2, de acordo com decreto estadual $n^{0}$ 10.755/77 e observada a resolução CONAMA 20/86. Ao longo desse rio existem trechos em desconformidade com o enquadramento. Este 
é o caso do trecho que se inicia logo após a confluência do ribeirão das Anhumas até a barragem do reservatório de Salto Grande. De acordo com o relatório de qualidade das águas interiores do Estado de São Paulo de 2000 (CETESB, 2001), esse trecho apresenta valores críticos de matéria orgânica biodegradável, amônia, fósforo total, alumínio, fenóis e coliforme fecal no ponto ATIB02605 na entrada do reservatório de Salto Grande, junto à captação da cidade de Sumaré. Este ponto de monitoramento situa-se a jusante do pólo industrial de Paulínia e do ribeirão Anhumas, no qual cerca de 10,3 tDBO/dia de origem doméstica são despejados do município de Campinas. Trata-se, portanto, de um trecho comprometido em relação à qualidade da água, onde se observa escassez relativa dos recursos hídricos.

A TABELA 23 mostra os valores dos parâmetros de qualidade utilizados pela CETESB no cálculo do Índice de Qualidade das Águas (IQA), para o ano de 2000, no posto ATIB02605. Os parâmetros coletados nesse posto retratam o estado da água afluente a represa de Salto Grande. O IQA incorpora nove parâmetros considerados relevantes à avaliação da qualidade da água voltada ao abastecimento público. Além dos usados no IQA, a TABELA 23 apresenta outros parâmetros considerados críticos para o trecho estudado.

TABELA 23 - Parâmetros de qualidade da água do rio Atibaia em 2000.

\begin{tabular}{|c|c|c|c|c|c|c|c|}
\hline \multicolumn{8}{|c|}{$\begin{array}{l}\text { LOCAL: RIO ATIBAIA, PONTE NA RODOVIA SP-332, NO } \\
\text { CÓDIGO DO POSTO: ATIB02605 } \\
\text { ENQRADRAMENTO: CLASSE } 2 \\
\end{array}$} \\
\hline PARÂMETROS UTILIZADOS NO IQA & $\begin{array}{c}\text { PADRÃO DE } \\
\text { QUALIDADE } \\
\text { CONAMA 20/86 } \\
\end{array}$ & JAN & MAR & MAI & JUL & SET & NOV \\
\hline TEMPERATURA DA ÁGUA $\left({ }^{\circ} \mathrm{C}\right)$ & & 27 & 26 & 25 & 22 & 25 & 24 \\
\hline $\mathrm{pH}$ & 6,0 a 9,0 & 7,4 & 7,0 & 7,0 & 7,5 & 7,1 & 7,3 \\
\hline OXIGÊNIO DISSOLVIDO $\left(\mathrm{mgO}_{2} / \mathrm{L}\right)$ & 5,0 & 5,4 & 5,9 & 5,5 & 5,6 & 5,7 & 6,0 \\
\hline $\mathrm{DBO}_{5,20}\left(\mathrm{mgO}_{2} / \mathrm{L}\right)$ & 5 & 5 & 3 & 5 & 7 & 15 & 10 \\
\hline NITROGÊNIO TOTAL (mgN/L) & & 1,76 & 3,58 & 4,70 & 6,63 & 2,70 & 2,39 \\
\hline FÓSFORO TOTAL (mgP/L) & 0,025 & 0,411 & 0,260 & 0,258 & 0,548 & 0,299 & 0,356 \\
\hline RESÍDUO TOTAL (mg/L) & & 304 & 186 & 323 & 423 & 270 & 237 \\
\hline TURBIDEZ (UNT) & 100 & 110 & 37 & 10 & 8 & 75 & 85 \\
\hline COLIFORME FECAL (NMP/100mL) & $1,0 \mathrm{E}+03$ & $3,0 \mathrm{E}+05$ & $1,7 \mathrm{E}+04$ & $2,2 \mathrm{E}+04$ & $2,3 \mathrm{E}+04$ & $1,3 \mathrm{E}+05$ & $1,3 \mathrm{E}+04$ \\
\hline \multicolumn{8}{|l|}{ OUTROS PARÂMETROS CRÍTICOS } \\
\hline NITROGÊNIO AMÔNIACAL (mgN/L) & 1,0 & 0,63 & 1,27 & 2,50 & 4,60 & 1,20 & 1,00 \\
\hline ALUMÍNIO (mg/L) & 0,1 & 4,28 & 4,57 & 0,54 & 0,20 & 7,03 & 2,74 \\
\hline FENÓIS (mg/L) & 0,001 & $<0,003$ & 0,010 & 0,032 & 0,065 & 0,012 & 0,005 \\
\hline MANGANÊS (mg/L) & 0,10 & 0,16 & 0,12 & 0,08 & 0,07 & 0,19 & 0,15 \\
\hline
\end{tabular}

Fonte: Adaptado de CETESB (2001). 
Percebe-se que em 2000, alguns parâmetros apresentaram concentrações fora dos limites estabelecidos pela resolução CONAMA 20/86. Entre eles destacam-se a Demanda Bioquímica de Oxigênio $\left(\mathrm{DBO}_{5,}{ }_{20}\right)$ e o Fósforo Total - principal nutriente responsável pelo processo de eutrofização verificado em Salto Grande. Cabe destacar que esta é uma tendência verificada em anos anteriores ao de 2000.

RIOS (1999) e TEIXEIRA (2000), por meio de estudos realizados em Salto Grande, confirmaram o processo de eutrofização nesse corpo de água. Um sintoma característico desse processo é o aumento da biomassa de algas e plantas aquáticas; além disso, a diminuição da transparência da água; redução do volume útil dos reservatórios devido à sedimentação; queda na concentração de oxigênio dissolvido; odores desagradáveis e mortandade de peixes. A FIGURA 5 retrata a presença do processo de eutrofização no reservatório de Salto Grande, ao identificar a presença de um banco de macrófitas aquáticas - um dos sintomas de ocorrência do referido processo - que nesse corpo de água cobre aproximadamente $10 \%$ da área da bacia hidráulica. (RIOS, 1999)

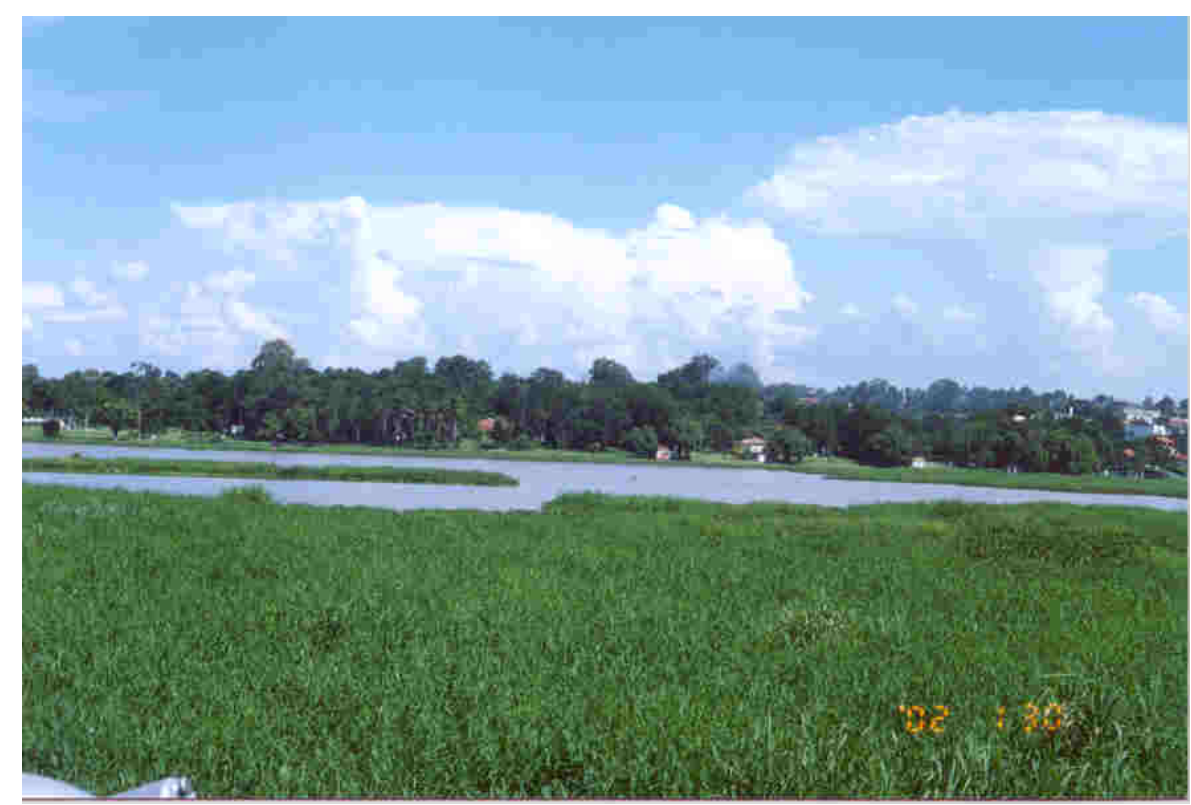

FIGURA 5 - Banco de macrófitas no reservatório de Salto Grande (2001).

De acordo com TEIXEIRA (2000), a matéria orgânica de origem doméstica é o principal poluente responsável pelo processo de eutrofização no reservatório de Salto Grande. Neste caso, são esgotos provenientes de Campinas e Paulínia que interferem 
na qualidade da água dessa represa, que está periodicamente em desconformidade com os padrões de qualidade estabelecidos para esse trecho do rio Atibaia.

As TABELAS 25, 26 e 27 apresentam as principais fontes pontuais de poluição no trecho do rio Atibaia onde se localiza o reservatório. Assim, são apresentados os cenários de cargas poluidoras potenciais e remanescentes de DBO, para os anos de 2000, 2005 e 2010. Entende-se por cargas poluidoras potenciais, o total de poluição gerada, antes de passar por qualquer tipo de abatimento. Após o abatimento tem-se, caracterizada, as cargas poluidoras remanescentes.

Nos cenários de 2005 e 2010 são considerados os investimentos que têm sido realizados na construção de sistemas de tratamento de esgoto urbano, inseridos no Projeto de Qualidade das Águas e Controle da Poluição Hídrica (PQA), cujo término está previsto para o final de 2004. A TABELA 24 apresenta, para o trecho estudado, estações de tratamento de esgotos propostas ou em obras.

TABELA 24 - Estações de tratamento de esgoto propostas ou em obras.

\begin{tabular}{c|c|c|c}
\hline Município & Corpo Receptor & Tipo de tratamento & Capacidade (L/s) \\
\hline Campinas & Rib. das Pedras & Lodo ativado & 200 \\
Campinas & Rib. Anhumas & Lodo ativado & 600 \\
Paulínia & Rio Atibaia & Lagoa aerada e de decantação & 122 \\
Americana & Res. de Salto Grande & $\begin{array}{c}\text { Lodo ativado com valo de } \\
\text { oxidação (em obras) }\end{array}$ & 75 \\
\hline
\end{tabular}

Fonte: Baseada em dados de COPLAENGE (2000).

Esses investimentos contribuirão para a diminuição das cargas poluidoras e, por conseqüência, para escassez relativa verificada no referido trecho do rio Atibaia.

Para as pretensões deste estudo e aplicação da metodologia de cobrança sobre os usos da água no reservatório, o parâmetro de poluição escolhido foi a DBO - pela facilidade de obtenção dos dados. Apesar de o Fósforo Total ser o parâmetro ambiental que representa a pior situação no trecho, a escolha da DBO não invalida as simulações realizadas, pois se trata de um parâmetro que tem os limites de saturação permanentemente fora do estabelecido na Resolução CONAMA 20/86, como visto na TABELA 23. 
TABELA 25 - Cargas poluidoras pontuais potenciais e remanescentes no trecho do rio Atibaia, desde a confluência do ribeirão Anhumas até o início da bacia hidráulica da represa de Salto Grande em 2000.

\begin{tabular}{l|c|c}
\hline \multirow{2}{*}{ Fonte Poluidora } & \multicolumn{2}{c}{ Carga Poluidora (kg/DBO/dia) } \\
\cline { 2 - 3 } & Potencial & Remanescente \\
\hline Campinas (29\% da carga total) & 14.480 & 10.300 \\
Indústrias & 27.983 & 4.932 \\
Paulínia & 2.498 & 2.299 \\
TOTAL & 44.961 & 17.531 \\
\hline
\end{tabular}

Fonte: Baseada em dados de COPLAENGE (2000).

TABELA 26 - Cargas poluidoras pontuais potenciais e remanescentes no trecho do rio Atibaia, desde a confluência do ribeirão Anhumas até o início da bacia hidráulica da represa de Salto Grande em 2005.

\begin{tabular}{l|c|c}
\hline \multirow{2}{*}{\multicolumn{1}{c|}{ Fonte Poluidora }} & \multicolumn{2}{c}{ Carga Poluidora (kg/DBO/dia) } \\
\cline { 2 - 3 } & Potencial & Remanescente \\
\hline Campinas (29\% da carga total) & 15.372 & 1.484 \\
Indústrias & 27.983 & 4.932 \\
Paulínia & 2.990 & 322 \\
TOTAL & 46.345 & 6.738 \\
\hline
\end{tabular}

Fonte: Baseada em dados de COPLAENGE (2000).

TABELA 27 - Cargas poluidoras pontuais potenciais e remanescentes no trecho do rio Atibaia, desde a confluência do ribeirão Anhumas até o início da bacia hidráulica da represa de Salto Grande em 2010.

\begin{tabular}{l|c|c}
\hline \multirow{2}{*}{\multicolumn{1}{c|}{ Fonte Poluidora }} & \multicolumn{2}{c}{ Carga Poluidora (kg/DBO/dia) } \\
\cline { 2 - 3 } & Potencial & Remanescente \\
\hline Campinas (29\% da carga total) & 16.045 & 1.398 \\
Indústrias & 27.983 & 4.932 \\
Paulínia & 3.523 & 194 \\
TOTAL & 47.551 & 6.524 \\
\hline
\end{tabular}

Fonte: Baseada em dados de COPLAENGE (2000). 
Nas simulações realizadas não foram consideradas as cargas poluidoras difusas urbanas e rurais existentes no trecho. Percebe-se que, nas diversas fontes de consulta, existem deficiências em relação a este tipo de informação, um exemplo é a falta de um cadastro sistematizado de irrigantes. Cabe salientar, ainda, que para os cenários estabelecidos não foi considerado acréscimo ou decréscimo nas cargas poluidoras de origem industrial. Todavia, com a introdução da cobrança e a efetivação da outorga como instrumentos de gestão, espera-se que a poluição industrial diminua ao longo do tempo, por meio do uso de sistemas de tratamento de efluentes mais eficientes ou tecnologias menos consumidoras de água.

\subsubsection{Cobrança sobre captação para abastecimento da cidade de Sumaré}

A cidade de Sumaré localiza-se na bacia do rio Piracicaba - área conurbada de Campinas. Uma de suas fontes de água para abastecimento humano é o reservatório de Salto Grande, que consegue atender cerca de 70\% da população urbana de Sumaré - município que possui um índice de urbanização em torno de 99,45\%. Na TABELA 28 estão as projeções de: população, demanda total de água e demanda de água do reservatório de Salto Grande para abastecimento de Sumaré.

TABELA 28 - Projeções demográficas e demandas de água para cidade de Sumaré.

\begin{tabular}{c|ccc}
\hline & 2000 & 2005 & 2010 \\
\hline População urbana (hab) & 191.201 & 225.039 & 261.472 \\
$\begin{array}{c}\text { Demanda total de água }\left(\mathrm{m}^{3} / \mathrm{s}\right) \\
\begin{array}{c}\text { Demanda atendida pelo } \\
\text { reservatório }\left(\mathrm{m}^{3} / \mathrm{s}\right)\end{array}\end{array}$ & 0,626 & 0,716 & 0,832 \\
\hline
\end{tabular}

Fonte: Baseada em dados de COPLAENGE (2000).

As TABELAS 29, 30 e 31 apresentam os resultados obtidos das simulações da cobrança sobre captação para abastecimento da cidade de Sumaré nos anos de 2000, 2005 e 2010, respectivamente. Foi utilizado o regime de vazões médias mensais, com intuito de representar a sazonalidade existente e mostrar a variação que ocorre nos valores da cobrança durante o ano. Cabe observar que parte alguma da água captada por Sumaré retorna ao rio Atibaia, portanto a vazão consumida é igual à captada. 
TABELA 29 - Cobrança sobre captação no reservatório de Salto Grande para abastecimento da cidade de Sumaré em 2000.

\begin{tabular}{|c|c|c|c|c|c|c|c|c|c|c|c|c|}
\hline Variáveis & Jan & Fev & Mar & Abr & Mai & Jun & Jul & Ago & Set & Out & Nov & Dez \\
\hline $\mathrm{Q}(\mathrm{L} / \mathrm{s})$ & 55.500 & 52.800 & 50.300 & 36.500 & 31.400 & 33.500 & 26.600 & 21.500 & 26.900 & 30.200 & 33.000 & 43.900 \\
\hline c (mg/L) & 5 & 5 & 5 & 5 & 5 & 5 & 5 & 5 & 5 & 5 & 5 & 5 \\
\hline Cs (mg/s) & 277.500 & 264.000 & 251.500 & 182.500 & 157.000 & 167.500 & 133.000 & 107.500 & 134.500 & 151.000 & 165.000 & 219.500 \\
\hline$\sum \mathrm{Ce}(\mathrm{mg} / \mathrm{s})^{*}$ & 141.037 & 141.037 & 141.037 & 141.037 & 141.037 & 141.037 & 141.037 & 141.037 & 141.037 & 141.037 & 141.037 & 141.037 \\
\hline Qcon (L/s) & 432 & 432 & 432 & 432 & 432 & 432 & 432 & 432 & 432 & 432 & 432 & 432 \\
\hline ср (mg/L) & 60 & 60 & 60 & 60 & 60 & 60 & 60 & 60 & 60 & 60 & 60 & 60 \\
\hline $\mathrm{S}$ & 1 & 1 & 1 & 1 & 1 & 1 & 1 & 1 & 1 & 1 & 1 & 1 \\
\hline $\mathrm{I}_{1}$ & 0,492 & 0,466 & 0,439 & 0,227 & 0,102 & 0,158 & $-0,060$ & $-0,312$ & $-0,049$ & 0,066 & 0,145 & 0,357 \\
\hline $\mathrm{K}_{1} * *$ & 321,59 & 332,85 & 344,18 & 429,42 & 476,42 & 455,60 & $8.747,32$ & $10.045,30$ & $8.683,79$ & 489,40 & 460,36 & 378,07 \\
\hline $\mathrm{I}_{2}$ & 0,488 & 0,461 & 0,434 & 0,218 & 0,089 & 0,147 & $-0,078$ & $-0,339$ & $-0,066$ & 0,052 & 0,134 & 0,351 \\
\hline $\mathrm{K}_{2} * *$ & 323,33 & 334,74 & 346,23 & 432,97 & 480,99 & 459,70 & $8.840,92$ & 10.178,71 & $8.775,65$ & 494,29 & 464,56 & 380,65 \\
\hline$\left(\mathrm{K}_{2}-\mathrm{K}_{1}\right)^{* *}$ & 1,74 & 1,89 & 2,05 & 3,54 & 4,58 & 4,10 & 93,60 & 133,41 & 91,87 & 4,89 & 4,20 & 2,59 \\
\hline $\mathrm{T}_{\mathrm{c}}$ (US\$/mês) & 4.086,90 & $4.447,80$ & $4.829,45$ & $8.326,75$ & $10.756,07$ & $9.634,26$ & $220.006,82$ & $313.596,88$ & 215.940,30 & $11.493,60$ & $9.883,90$ & $6.084,79$ \\
\hline
\end{tabular}

* Somatório das cargas poluidoras remanescentes a montante da captação (Campinas e Indústrias - TABELA 25), descontados 20\% de autodepuração (valor arbitrado)

** (US\$/mês)/(L/s)

\begin{tabular}{c|cc}
\hline Arrecadação em 2000 & \multicolumn{2}{|c}{ Cobrança Unitária } \\
\hline (US\$/ano) & (US\$/mªno) & (US\$/hab/ano) \\
\hline $819.087,52$ & 0,060 & 4,28 \\
\hline
\end{tabular}


TABELA 30 - Cobrança sobre captação no reservatório de Salto Grande para abastecimento da cidade de Sumaré em 2005.

\begin{tabular}{|c|c|c|c|c|c|c|c|c|c|c|c|c|}
\hline Variáveis & Jan & $\mathrm{Fev}$ & Mar & Abr & Mai & Jun & Jul & Ago & Set & Out & Nov & Dez \\
\hline $\mathrm{Q}(\mathrm{L} / \mathrm{s})$ & 55.500 & 52.800 & 50.300 & 36.500 & 31.400 & 33.500 & 26.600 & 21.500 & 26.900 & 30.200 & 33.000 & 43.900 \\
\hline c $(\mathrm{mg} / \mathrm{L})$ & 5 & 5 & 5 & 5 & 5 & 5 & 5 & 5 & 5 & 5 & 5 & 5 \\
\hline Cs (mg/s) & 277.500 & 264.000 & 251.500 & 182.500 & 157.000 & 167.500 & 133.000 & 107.500 & 134.500 & 151.000 & 165.000 & 219.500 \\
\hline$\sum \mathrm{Ce}(\mathrm{mg} / \mathrm{s})^{*}$ & 59.407 & 59.407 & 59.407 & 59.407 & 59.407 & 59.407 & 59.407 & 59.407 & 59.407 & 59.407 & 59.407 & 59.407 \\
\hline Qcon (L/s) & 495 & 495 & 495 & 495 & 495 & 495 & 495 & 495 & 495 & 495 & 495 & 495 \\
\hline cp (mg/L) & 60 & 60 & 60 & 60 & 60 & 60 & 60 & 60 & 60 & 60 & 60 & 60 \\
\hline S & 1 & 1 & 1 & 1 & 1 & 1 & 1 & 1 & 1 & 1 & 1 & 1 \\
\hline $\mathrm{I}_{1}$ & 0,786 & 0,775 & 0,764 & 0,674 & 0,622 & 0,645 & 0,553 & 0,447 & 0,558 & 0,607 & 0,640 & 0,729 \\
\hline $\mathrm{K}_{1} * *$ & 177,10 & 183,30 & 189,54 & 236,48 & 262,36 & 250,90 & 294,18 & 340,72 & 291,91 & 269,51 & 253,51 & 208,20 \\
\hline $\mathrm{I}_{2}$ & 0,784 & 0,773 & 0,761 & 0,670 & 0,616 & 0,640 & 0,545 & 0,434 & 0,550 & 0,600 & 0,634 & 0,726 \\
\hline $\mathrm{K}_{2} * *$ & 178,20 & 184,49 & 190,83 & 238,72 & 265,25 & 253,49 & 298,01 & 346,24 & 295,67 & 272,60 & 256,17 & 209,83 \\
\hline$\left(\mathrm{K}_{2}-\mathrm{K}_{1}\right)^{* *}$ & 1,10 & 1,20 & 1,30 & 2,24 & 2,89 & 2,59 & 3,84 & 5,52 & 3,76 & 3,09 & 2,66 & 1,64 \\
\hline $\mathrm{T}_{\mathrm{c}}$ (US\$/mês) & $1.087,30$ & $1.183,37$ & $1.284,98$ & $2.216,41$ & $2.863,75$ & $2.564,79$ & $3.799,77$ & $5.465,61$ & $3.727,76$ & $3.060,32$ & $2.631,31$ & $1.619,24$ \\
\hline
\end{tabular}

* Somatório das cargas poluidoras remanescentes a montante da captação (Campinas e Indústrias - TABELA 26), descontados 20\% de autodepuração (valor arbitrado)

** (US\$/mês)/(L/s)

\begin{tabular}{c|cc}
\hline Arrecadação em 2005 & \multicolumn{2}{|c}{ Cobrança Unitária } \\
\hline (US\$/ano) & (US\$/mªno) & (US\$/hab/ano) \\
\hline $31.504,61$ & 0,002 & 0,14 \\
\hline
\end{tabular}


TABELA 31 - Cobrança sobre captação no reservatório de Salto Grande para abastecimento da cidade de Sumaré em 2010.

\begin{tabular}{|c|c|c|c|c|c|c|c|c|c|c|c|c|}
\hline Variáveis & Jan & $\mathrm{Fev}$ & Mar & Abr & Mai & Jun & Jul & Ago & Set & Out & Nov & Dez \\
\hline $\mathrm{Q}(\mathrm{L} / \mathrm{s})$ & 55.500 & 52.800 & 50.300 & 36.500 & 31.400 & 33.500 & 26.600 & 21.500 & 26.900 & 30.200 & 33.000 & 43.900 \\
\hline c $(\mathrm{mg} / \mathrm{L})$ & 5 & 5 & 5 & 5 & 5 & 5 & 5 & 5 & 5 & 5 & 5 & 5 \\
\hline Cs (mg/s) & 277.500 & 264.000 & 251.500 & 182.500 & 157.000 & 167.500 & 133.000 & 107.500 & 134.500 & 151.000 & 165.000 & 219.500 \\
\hline$\sum \mathrm{Ce}(\mathrm{mg} / \mathrm{s})^{*}$ & 58.611 & 58.611 & 58.611 & 58.611 & 58.611 & 58.611 & 58.611 & 58.611 & 58.611 & 58.611 & 58.611 & 58.611 \\
\hline Qcon (L/s) & 576 & 576 & 576 & 576 & 576 & 576 & 576 & 576 & 576 & 576 & 576 & 576 \\
\hline cp (mg/L) & 60 & 60 & 60 & 60 & 60 & 60 & 60 & 60 & 60 & 60 & 60 & 60 \\
\hline S & 1 & 1 & 1 & 1 & 1 & 1 & 1 & 1 & 1 & 1 & 1 & 1 \\
\hline $\mathrm{I}_{1}$ & 0,789 & 0,778 & 0,767 & 0,679 & 0,627 & 0,650 & 0,559 & 0,455 & 0,564 & 0,612 & 0,645 & 0,733 \\
\hline $\mathrm{K}_{1} * *$ & 175,46 & 181,60 & 187,78 & 234,29 & 259,93 & 248,57 & 291,45 & 337,56 & 289,20 & 267,01 & 251,16 & 206,27 \\
\hline $\mathrm{I}_{2}$ & 0,787 & 0,776 & 0,764 & 0,674 & 0,620 & 0,644 & 0,550 & 0,440 & 0,555 & 0,604 & 0,638 & 0,729 \\
\hline $\mathrm{K}_{2} * *$ & 176,72 & 182,98 & 189,28 & 236,87 & 263,27 & 251,56 & 295,89 & 343,94 & 293,56 & 270,58 & 254,24 & 208,16 \\
\hline$\left(\mathrm{K}_{2}-\mathrm{K}_{1}\right)^{* *}$ & 1,27 & 1,38 & 1,50 & 2,59 & 3,34 & 2,99 & 4,44 & 6,38 & 4,35 & 3,57 & 3,07 & 1,89 \\
\hline $\mathrm{T}_{\mathrm{c}}$ (US\$/mês) & $1.238,24$ & $1.347,74$ & $1.463,55$ & $2.525,77$ & $3.264,47$ & $2.923,27$ & $4.333,24$ & $6.236,93$ & $4.251,00$ & $3.488,87$ & $2.999,19$ & $1.844,65$ \\
\hline
\end{tabular}

* Somatório das cargas poluidoras remanescentes a montante da captação (Campinas e Indústrias - TABELA 27), descontados 20\% de autodepuração (valor arbitrado)

** (US\$/mês)/(L/s)

\begin{tabular}{c|cc}
\hline Arrecadação em 2010 & \multicolumn{2}{|c}{ Cobrança Unitária } \\
\hline (US\$/ano) & (US\$/mªno) & (US\$/hab/ano) \\
\hline $35.916,92$ & 0,002 & 0,14 \\
\hline
\end{tabular}


Os resultados das simulações feitas para os três cenários mostram, de maneira clara, as diferenças entre os valores cobrados ao longo do ano e em anos diferentes. A partir de 2005 nota-se um decréscimo brusco do valor arrecadado - proporcional à diminuição da carga remanescente lançada, a qual representa o comprometimento do trecho do corpo de água. Já a partir de 2010, com o pequeno decréscimo de carga remanescente e aumento do volume captado, o montante cobrado nesse ano cresce cerca de $14 \%$ em relação a 2005; neste caso, o aumento é proporcional ao acréscimo na captação.

Em 2000, os valores unitários de cobrança variariam de US\$ 0,27/ $\mathrm{m}^{3}$ no mês de junho a US\$ $0,0035 / \mathrm{m}^{3}$ no mês de janeiro. No ano, a cobrança unitária média estaria em torno de US\$ 0,06/ $\mathrm{m}^{3}$. Este valor é maior que o estipulado para ser cobrado na proposta do Estado de São Paulo $\left(\mathrm{R} \$ 0,01 / \mathrm{m}^{3}\right)$. Se for considerada uma cotação média do dólar para o ano de 2000 ( $\mathrm{R}$ \$ 1,83), o valor médio anual da cobrança sobre a captação para abastecimento da cidade de Sumaré seria de R $0,11 / \mathrm{m}^{3}$. Para efeito de comparação e ilustração, se esta situação ocorresse no México, o valor estimado para a cobrança unitária seria de US $\$ 0,027 / \mathrm{m}^{3}$. Portanto, em uma mesma ordem de grandeza.

Baseado nas simulações percebe-se que a uniformização, para todo o Estado de São Paulo, de um valor fixo - neste caso $\mathrm{R} \$ 0,01 / \mathrm{m}^{3}$ - poderá não representar, em muitas situações, o real valor do recurso hídrico - independentemente do usuário, da época do ano e de sua localização. Neste caso, o instrumento perde sua capacidade de incentivar a conduta racional perante o consumo de água; assim, a finalidade do instrumento econômico na gestão passa a ser o cumprimento de uma obrigação (o pagamento).

Cabe destacar que, não é pelo fato de o valor cobrado ser alto que o sistema de cobrança atingirá seus objetivos; existem condicionantes de natureza econômica, como a elasticidade preço da demanda, - e de natureza institucional que devem ser observados dentro de um sistema de gestão - no qual a cobrança é apenas um dos instrumentos. Entretanto, um dos primeiros passos é a busca de um valor que retrate quanto o recurso natural realmente vale para uma sociedade. Nesse caso, o conceito de escassez relativa deve ser incorporado em qualquer sistema de cobrança que não vise apenas a arrecadação. 
Na simulação realizada para o ano de 2005, percebe-se drástica mudança no valor cobrado. Em relação a 2000, o montante arrecadado em 2005 representaria cerca de 3,85\%. Este resultado deixa clara a importância dos investimentos previstos, em sistemas de tratamento de esgoto. Esses sistemas possibilitarão diminuição de 61,6\% da carga poluidora remanescente no trecho analisado. Para o ano de 2005 a cobrança unitária média atingiria valores de US\$ $0,002 / \mathrm{m}^{3}$ - mesmo valor unitário observado na simulação feita para 2010.

Segundo o Departamento de Água e Esgoto de Sumaré, o custo unitário dos processos físico-químicos envolvidos no tratamento da água derivada do reservatório de Salto Grande era de $\mathrm{R} \$ 1,65 / \mathrm{m}^{3}$ em 2000 . Caso a cobrança fosse somada a esse custo, ela representaria cerca 6,25\% do custo total unitário. Cabe destacar que, com os investimentos realizados ao longo dos anos em sistemas de tratamento de esgoto, o custo de tratamento da água tende a diminuir, motivado pela melhoria da qualidade da água captada. Essa tendência também é seguida pelos custos com a cobrança.

\subsubsection{Cobrança sobre captação do setor agropecuário}

No entorno do reservatório de Salto Grande há diversos tipos de ocupações e usos do solo, os quais demandam água e a utilizam por meio de sistemas de captação particulares. É o caso do setor agropecuário, cujas demandas de água foram obtidas de estudo realizado pela Secretaria do Meio Ambiente em 1994, no qual a bacia do rio Atibaia foi dividida em compartimentos ambientais. Foram usadas demandas do compartimento ambiental Salto Grande, que abrange apenas o reservatório e sua área de influência. (SÃO PAULO, 1994)

A TABELA 32 apresenta as demandas de água do referido setor para os três períodos simulados. Nas TABELAS 33, 34 e 35 estão os resultados das simulações da cobrança sobre consumo de água do setor agropecuário em Salto Grande.

TABELA 32 - Demandas de água em Salto Grande para o setor agropecuário.

\begin{tabular}{l|lll}
\hline & 2000 & 2005 & 2010 \\
\hline Demanda $\left(\mathrm{m}^{3} / \mathrm{s}\right)$ & 0,019 & 0,021 & 0,023 \\
\hline
\end{tabular}

Fonte: SÃO PAULO (1994) 
TABELA 33 - Cobrança sobre captação no reservatório de Salto Grande para atendimento ao setor agropecuário em 2000.

\begin{tabular}{|c|c|c|c|c|c|c|c|c|c|c|c|c|}
\hline Variáveis & Jan & $\mathrm{Fev}$ & Mar & Abr & Mai & Jun & Jul & Ago & Set & Out & Nov & Dez \\
\hline $\mathrm{Q}(\mathrm{L} / \mathrm{s})$ & 55.500 & 52.800 & 50.300 & 36.500 & 31.400 & 33.500 & 26.600 & 21.500 & 26.900 & 30.200 & 33.000 & 43.900 \\
\hline c $(\mathrm{mg} / \mathrm{L})$ & 5 & 5 & 5 & 5 & 5 & 5 & 5 & 5 & 5 & 5 & 5 & 5 \\
\hline Cs (mg/s) & 277.500 & 264.000 & 251.500 & 182.500 & 157.000 & 167.500 & 133.000 & 107.500 & 134.500 & 151.000 & 165.000 & 219.500 \\
\hline$\sum \mathrm{Ce}(\mathrm{mg} / \mathrm{s})^{*}$ & 162.324 & 162.324 & 162.324 & 162.324 & 162.324 & 162.324 & 162.324 & 162.324 & 162.324 & 162.324 & 162.324 & 162.324 \\
\hline Qcon (L/s) & 19 & 19 & 19 & 19 & 19 & 19 & 19 & 19 & 19 & 19 & 19 & 19 \\
\hline ср (mg/L) & 60 & 60 & 60 & 60 & 60 & 60 & 60 & 60 & 60 & 60 & 60 & 60 \\
\hline S & 1 & 1 & 1 & 1 & 1 & 1 & 1 & 1 & 1 & 1 & 1 & 1 \\
\hline $\mathrm{I}_{1}$ & 0,415 & 0,385 & 0,355 & 0,111 & $-0,034$ & 0,031 & $-0,220$ & $-0,510$ & $-0,207$ & $-0,075$ & 0,016 & 0,260 \\
\hline $\mathrm{K}_{1} * *$ & 354,35 & 366,75 & 379,24 & 473,16 & $8.604,51$ & 502,01 & $9.584,23$ & $11.006,40$ & $9.514,62$ & $8.825,23$ & 931,74 & 416,57 \\
\hline $\mathrm{I}_{2}$ & 0,415 & 0,385 & 0,354 & 0,110 & $-0,035$ & 0,030 & $-0,221$ & $-0,511$ & $-0,208$ & $-0,076$ & 0,016 & 0,260 \\
\hline $\mathrm{K}_{2} * *$ & 354,43 & 366,84 & 379,34 & 473,33 & $8.607,90$ & 502,21 & $9.588,68$ & $11.012,73$ & $9.518,99$ & $8.828,84$ & 932,10 & 416,70 \\
\hline$\left(\mathrm{K}_{2}-\mathrm{K}_{1}\right)^{* *}$ & 0,08 & 0,09 & 0,10 & 0,17 & 3,39 & 0,20 & 4,45 & 6,33 & 4,37 & 3,61 & 0,36 & 0,12 \\
\hline $\mathrm{T}_{\mathrm{c}}$ (US\$/mês) & 226,51 & 246,44 & 267,49 & 459,98 & $9.160,34$ & 531,75 & $12.045,65$ & $17.116,78$ & $11.824,72$ & $9.768,84$ & 972,85 & 336,68 \\
\hline
\end{tabular}

* Somatório das cargas poluidoras remanescentes no trecho em estudo (TABELA 25), descontados 20\% de autodepuração (valor arbitrado)

** (US\$/mês)/(L/s)

\begin{tabular}{c|cc}
\hline Arrecadação em 2000 & \multicolumn{2}{|c}{ Cobrança Unitária } \\
\hline (US\$/ano) & (US\$/mªno) & (US\$/ha/ano) \\
\hline $62.958,04$ & 0,105 & $1.144,70$ \\
\hline
\end{tabular}


TABELA 34 - Cobrança sobre captação no reservatório de Salto Grande para atendimento ao setor agropecuário em 2005.

\begin{tabular}{|c|c|c|c|c|c|c|c|c|c|c|c|c|}
\hline Variáveis & Jan & Fev & Mar & Abr & Mai & Jun & Jul & Ago & Set & Out & Nov & Dez \\
\hline $\mathrm{Q}(\mathrm{L} / \mathrm{s})$ & 55.500 & 52.800 & 50.300 & 36.500 & 31.400 & 33.500 & 26.600 & 21.500 & 26.900 & 30.200 & 33.000 & 43.900 \\
\hline c $(\mathrm{mg} / \mathrm{L})$ & 5 & 5 & 5 & 5 & 5 & 5 & 5 & 5 & 5 & 5 & 5 & 5 \\
\hline Cs (mg/s) & 277.500 & 264.000 & 251.500 & 182.500 & 157.000 & 167.500 & 133.000 & 107.500 & 134.500 & 151.000 & 165.000 & 219.500 \\
\hline$\sum \mathrm{Ce}(\mathrm{mg} / \mathrm{s})^{*}$ & 62.389 & 62.389 & 62.389 & 62.389 & 62.389 & 62.389 & 62.389 & 62.389 & 62.389 & 62.389 & 62.389 & 62.389 \\
\hline Qcon (L/s) & 21 & 21 & 21 & 21 & 21 & 21 & 21 & 21 & 21 & 21 & 21 & 21 \\
\hline ср (mg/L) & 60 & 60 & 60 & 60 & 60 & 60 & 60 & 60 & 60 & 60 & 60 & 60 \\
\hline S & 1 & 1 & 1 & 1 & 1 & 1 & 1 & 1 & 1 & 1 & 1 & 1 \\
\hline $\mathrm{I}_{1}$ & 0,775 & 0,764 & 0,752 & 0,658 & 0,603 & 0,628 & 0,531 & 0,420 & 0,536 & 0,587 & 0,622 & 0,716 \\
\hline $\mathrm{K}_{1} * *$ & 183,19 & 189,60 & 196,05 & 244,61 & 271,38 & 259,52 & 304,29 & 352,43 & 301,94 & 278,77 & 262,23 & 215,35 \\
\hline $\mathrm{I}_{2}$ & 0,775 & 0,764 & 0,752 & 0,658 & 0,602 & 0,627 & 0,531 & 0,419 & 0,536 & 0,587 & 0,622 & 0,716 \\
\hline $\mathrm{K}_{2} * *$ & 183,23 & 189,65 & 196,11 & 244,71 & 271,50 & 259,63 & 304,45 & 352,67 & 302,10 & 278,90 & 262,34 & 215,42 \\
\hline$\left(\mathrm{K}_{2}-\mathrm{K}_{1}\right)^{* *}$ & 0,05 & 0,05 & 0,06 & 0,10 & 0,13 & 0,11 & 0,17 & 0,24 & 0,16 & 0,13 & 0,12 & 0,07 \\
\hline$\underline{\mathrm{T}_{\mathrm{c}} \text { (US\$/mês) }}$ & 49,75 & 54,12 & 58,75 & 101,02 & 130,29 & 116,78 & 172,47 & 247,18 & 169,23 & 139,16 & 119,79 & 73,94 \\
\hline
\end{tabular}

* Somatório das cargas poluidoras remanescentes no trecho em estudo (TABELA 26), descontados 20\% de autodepuração (valor arbitrado)

** (US\$/mês)/(L/s)

\begin{tabular}{c|cc}
\hline Arrecadação em 2005 & \multicolumn{2}{|c}{ Cobrança Unitária } \\
\hline (US\$/ano) & (US\$/mªno) & (US\$/ha/ano) \\
\hline $1.432,49$ & 0,002 & 23,87 \\
\hline
\end{tabular}


TABELA 35 - Cobrança sobre captação no reservatório de Salto Grande para atendimento ao setor agropecuário em 2010.

\begin{tabular}{|c|c|c|c|c|c|c|c|c|c|c|c|c|}
\hline Variáveis & Jan & Fev & Mar & Abr & Mai & Jun & Jul & Ago & Set & Out & Nov & Dez \\
\hline $\mathrm{Q}(\mathrm{L} / \mathrm{s})$ & 55.500 & 52.800 & 50.300 & 36.500 & 31.400 & 33.500 & 26.600 & 21.500 & 26.900 & 30.200 & 33.000 & 43.900 \\
\hline c $(\mathrm{mg} / \mathrm{L})$ & 5 & 5 & 5 & 5 & 5 & 5 & 5 & 5 & 5 & 5 & 5 & 5 \\
\hline Cs (mg/s) & 277.500 & 264.000 & 251.500 & 182.500 & 157.000 & 167.500 & 133.000 & 107.500 & 134.500 & 151.000 & 165.000 & 219.500 \\
\hline$\sum \mathrm{Ce}(\mathrm{mg} / \mathrm{s})^{*}$ & 60.407 & 60.407 & 60.407 & 60.407 & 60.407 & 60.407 & 60.407 & 60.407 & 60.407 & 60.407 & 60.407 & 60.407 \\
\hline Qcon (L/s) & 23 & 23 & 23 & 23 & 23 & 23 & 23 & 23 & 23 & 23 & 23 & 23 \\
\hline ср (mg/L) & 60 & 60 & 60 & 60 & 60 & 60 & 60 & 60 & 60 & 60 & 60 & 60 \\
\hline S & 1 & 1 & 1 & 1 & 1 & 1 & 1 & 1 & 1 & 1 & 1 & 1 \\
\hline $\mathrm{I}_{1}$ & 0,782 & 0,771 & 0,760 & 0,669 & 0,615 & 0,639 & 0,546 & 0,438 & 0,551 & 0,600 & 0,634 & 0,725 \\
\hline $\mathrm{K}_{1} * *$ & 179,15 & 185,42 & 191,73 & 239,22 & 265,40 & 253,80 & 297,58 & 344,66 & 295,29 & 272,63 & 256,45 & 210,61 \\
\hline $\mathrm{I}_{2}$ & 0,782 & 0,771 & 0,760 & 0,669 & 0,615 & 0,639 & 0,545 & 0,437 & 0,550 & 0,600 & 0,634 & 0,725 \\
\hline $\mathrm{K}_{2} * *$ & 179,20 & 185,48 & 191,79 & 239,32 & 265,53 & 253,92 & 297,76 & 344,92 & 295,46 & 272,77 & 256,57 & 210,69 \\
\hline$\left(\mathrm{K}_{2}-\mathrm{K}_{1}\right)^{* *}$ & 0,05 & 0,06 & 0,06 & 0,10 & 0,13 & 0,12 & 0,18 & 0,25 & 0,17 & 0,14 & 0,12 & 0,08 \\
\hline$\underline{\mathrm{T}_{\mathrm{c}} \text { (US\$/mês) }}$ & 51,59 & 56,13 & 60,93 & 104,77 & 135,13 & 121,12 & 178,88 & 256,37 & 175,52 & 144,33 & 124,24 & 76,69 \\
\hline
\end{tabular}

* Somatório das cargas poluidoras remanescentes no trecho em estudo (TABELA 27), descontados 20\% de autodepuração (valor arbitrado)

** (US\$/mês)/(L/s)

\begin{tabular}{c|cc}
\hline Arrecadação em 2010 & \multicolumn{2}{|c}{ Cobrança Unitária } \\
\hline (US\$/ano) & (US\$/mªno) & (US\$/ha/ano) \\
\hline $1.485,69$ & 0,002 & 22,51 \\
\hline
\end{tabular}


Os resultados das simulações realizadas para cobrança sobre consumo de água do setor agropecuário, retratam bem as diferenças sazonais que ocorrem durante o ano. Em 2000 a média dos valores cobrados nos meses mais secos (julho a outubro) seria cerca de 47 (quarenta e sete) vezes maior que nos meses mais chuvosos (dezembro a março). Ainda em 2000, os valores unitários de cobrança variariam entre US\$ $0,35 / \mathrm{m}^{3}$ em agosto e US\$ $0,00445 / \mathrm{m}^{3}$ no mês de janeiro. A cobrança unitária média durante o ano de 2000 seria de US\$ 0,105/m³ .

Com os avanços dos investimentos realizados na recuperação do rio Atibaia, especialmente do trecho estudado, a tendência é diminuir o valor cobrado, pois este retrata a escassez relativa. Assim, a partir de 2005 o setor agropecuário pagaria cerca de 2,3\%, em relação ao valor arrecadado em 2000, ou seja, um decréscimo de 97,7\% na cobrança, causado por uma diminuição de $61,6 \%$ da carga poluidora remanescente no referido trecho de rio. Já em 2010 o setor passaria a contribuir com 3,7\% a mais em relação a 2005, mesmo com diminuição da carga poluidora remanescente. Neste caso, o aumento do valor arrecadado é proporcional ao acréscimo no consumo. Nas simulações realizadas para os anos de 2005 e 2010, o valor médio anual da cobrança unitária seria de US\$0,002/m .

\subsubsection{Cobrança sobre lançamento de efluentes da cidade de Paulínia}

A cidade de Paulínia está situada na bacia do rio Atibaia (FIGURA 3), junto ao começo da área de inundação do reservatório de Salto Grande. Este corpo de água, além de receber cargas poluentes dos efluentes industriais das plantas localizadas em Paulínia, serve como corpo receptor direto de efluentes de origem doméstica gerados na cidade.

Como um dos objetivos deste trabalho é realizar simulações de cobrança sobre usos diretos da água do reservatório, as simulações para o setor industrial não fazem parte do escopo desta análise. Esses usuários não utilizam o reservatório de maneira direta, ou seja, não captam água e nem lançam efluentes diretamente no reservatório. Entretanto essas descargas industriais são próximas ao reservatório, fato que provoca grandes danos a esse sistema hídrico. As simulações de cobrança para esse setor industrial podem ser encontradas no trabalho de RIGHETTO (2001). 
Logo, somente a cidade de Paulínia utiliza, de maneira direta, o reservatório de Salto Grande; neste caso, para disposição e transporte dos efluentes de origem doméstica, gerados por população urbana estimada em 50 mil pessoas. Na TABELA 36 são apresentadas as projeções demográficas e de cargas poluidoras remanescentes geradas na cidade de Paulínia para os três cenários simulados. Cabe destacar que, a partir de 2005, é prevista uma diminuição de $86 \%$ da carga poluidora remanescente, devida à implantação de estação de tratamento de esgoto.

TABELA 36 - Projeção das cargas poluidoras remanescentes da cidade de Paulínia.

\begin{tabular}{c|ccc}
\hline & 2000 & 2005 & 2010 \\
\hline População urbana (hab) & 46.268 & 55.371 & 65.244 \\
$\begin{array}{c}\text { População urbana atendida } \\
\text { com coleta de esgoto (hab) }\end{array}$ & 41.641 & 49.834 & 58.720 \\
$\begin{array}{c}\text { Carga poluidora remanescente } \\
\text { (kg/DBO/dia) }\end{array}$ & 2.299 & 322 & 194 \\
\hline
\end{tabular}

Fonte: Baseada em dados de COPLAENGE (2000).

As TABELAS 37, 38 e 39 mostram os resultados das simulações da cobrança sobre lançamento de efluentes da cidade de Paulínia para os três cenários analisados. 
TABELA 37 - Cobrança sobre lançamento de efluentes líquidos de origem doméstica da cidade de Paulínia em 2000.

\begin{tabular}{|c|c|c|c|c|c|c|c|c|c|c|c|c|}
\hline Variáveis & Jan & Fev & Mar & Abr & Mai & Jun & Jul & Ago & Set & Out & Nov & Dez \\
\hline Q (L/s) & 55.500 & 52.800 & 50.300 & 36.500 & 31.400 & 33.500 & 26.600 & 21.500 & 26.900 & 30.200 & 33.000 & 43.900 \\
\hline c $(\mathrm{mg} / \mathrm{L})$ & 5 & 5 & 5 & 5 & 5 & 5 & 5 & 5 & 5 & 5 & 5 & 5 \\
\hline Cs (mg/s) & 277.500 & 264.000 & 251.500 & 182.500 & 157.000 & 167.500 & 133.000 & 107.500 & 134.500 & 151.000 & 165.000 & 219.500 \\
\hline $\mathrm{Ce}(\mathrm{mg} / \mathrm{s})^{*}$ & 26.609 & 26.609 & 26.609 & 26.609 & 26.609 & 26.609 & 26.609 & 26.609 & 26.609 & 26.609 & 26.609 & 26.609 \\
\hline$\sum \mathrm{Ce}(\mathrm{mg} / \mathrm{s})^{* *}$ & 162.324 & 162.324 & 162.324 & 162.324 & 162.324 & 162.324 & 162.324 & 162.324 & 162.324 & 162.324 & 162.324 & 162.324 \\
\hline ср (mg/L) & 60 & 60 & 60 & 60 & 60 & 60 & 60 & 60 & 60 & 60 & 60 & 60 \\
\hline $\mathrm{U}$ & 1 & 1 & 1 & 1 & 1 & 1 & 1 & 1 & 1 & 1 & 1 & 1 \\
\hline $\mathrm{I}_{\mathrm{C}}$ & 0,415 & 0,385 & 0,355 & 0,111 & $-0,034$ & 0,031 & $-0,220$ & $-0,510$ & $-0,207$ & $-0,075$ & 0,016 & 0,260 \\
\hline $\mathrm{K}_{\mathrm{c}} * * *$ & 354,35 & 366,75 & 379,24 & 473,16 & $8.604,51$ & 502,01 & $9.584,23$ & $11.006,40$ & $9.514,62$ & $8.825,23$ & 931,74 & 416,57 \\
\hline T (US\$/mês) & $157.147,4$ & $162.649,2$ & $168.185,1$ & 209.839,6 & $3.815 .956,4$ & $222.632,5$ & $4.250 .447,0$ & $4.881 .155,8$ & $4.219 .574,8$ & $3.913 .840,8$ & 413.209,6 & $184.743,4$ \\
\hline
\end{tabular}

* Carga remanescente lançada pelo usuário, igual ao produto entre a vazão do efluente final (Qe) e a concentração do poluente nesse efluente (ce)

** Somatório das cargas poluidoras remanescentes no trecho em estudo (TABELA 25), descontados 20\% de autodepuração (valor arbitrado)

*** (US\$/mês)/(L/s)

\begin{tabular}{c|cc}
\hline Arrecadação em 2000 & \multicolumn{2}{|c}{ Cobrança Unitária } \\
\hline (US\$/ano) & (US\$/kgDBO/ano) & (US\$/hab/ano) \\
\hline $22.599 .381,61$ & 26,932 & 542,72 \\
\hline
\end{tabular}


TABELA 38 - Cobrança sobre lançamento de efluentes líquidos de origem doméstica da cidade de Paulínia em 2005.

\begin{tabular}{|c|c|c|c|c|c|c|c|c|c|c|c|c|}
\hline Variáveis & Jan & Fev & Mar & Abr & Mai & Jun & Jul & Ago & Set & Out & Nov & Dez \\
\hline Q (L/s) & 55.500 & 52.800 & 50.300 & 36.500 & 31.400 & 33.500 & 26.600 & 21.500 & 26.900 & 30.200 & 33.000 & 43.900 \\
\hline c (mg/L) & 5 & 5 & 5 & 5 & 5 & 5 & 5 & 5 & 5 & 5 & 5 & 5 \\
\hline Cs (mg/s) & 277.500 & 264.000 & 251.500 & 182.500 & 157.000 & 167.500 & 133.000 & 107.500 & 134.500 & 151.000 & 165.000 & 219.500 \\
\hline $\mathrm{Ce}(\mathrm{mg} / \mathrm{s})^{*}$ & 3.727 & 3.727 & 3.727 & 3.727 & 3.727 & 3.727 & 3.727 & 3.727 & 3.727 & 3.727 & 3.727 & 3.727 \\
\hline$\sum \mathrm{Ce}(\mathrm{mg} / \mathrm{s})^{* *}$ & 62.389 & 62.389 & 62.389 & 62.389 & 62.389 & 62.389 & 62.389 & 62.389 & 62.389 & 62.389 & 62.389 & 62.389 \\
\hline ср (mg/L) & 60 & 60 & 60 & 60 & 60 & 60 & 60 & 60 & 60 & 60 & 60 & 60 \\
\hline $\mathrm{U}$ & 1 & 1 & 1 & 1 & 1 & 1 & 1 & 1 & 1 & 1 & 1 & 1 \\
\hline $\mathrm{I}_{\mathrm{c}}$ & 0,775 & 0,764 & 0,752 & 0,658 & 0,603 & 0,628 & 0,531 & 0,420 & 0,536 & 0,587 & 0,622 & 0,716 \\
\hline $\mathrm{K}_{\mathrm{c}} * * *$ & 183,19 & 189,60 & 196,05 & 244,61 & 271,38 & 259,52 & 304,29 & 352,43 & 301,94 & 278,77 & 262,23 & 215,35 \\
\hline Te (US\$/mês) & $11.378,86$ & $11.777,23$ & $12.178,08$ & $15.194,23$ & $16.856,96$ & $16.120,55$ & $18.901,33$ & 21.891,64 & $18.755,63$ & 17.316,33 & $16.288,69$ & $13.377,05$ \\
\hline
\end{tabular}

* Carga remanescente lançada pelo usuário, igual ao produto entre a vazão do efluente final (Qe) e a concentração do poluente nesse efluente (ce)

** Somatório das cargas poluidoras remanescentes no trecho em estudo (TABELA 26), descontados 20\% de autodepuração (valor arbitrado)

*** (US\$/mês)/(L/s)

\begin{tabular}{c|cc}
\hline Arrecadação em 2005 & \multicolumn{2}{|c}{ Cobrança Unitária } \\
\hline (US\$/ano) & (US\$/kgDBO/ano) & (US\$/hab/ano) \\
\hline $190.036,58$ & 1,617 & 3,81 \\
\hline
\end{tabular}


TABELA 39 - Cobrança sobre lançamento de efluentes líquidos de origem doméstica da cidade de Paulínia em 2010.

\begin{tabular}{|c|c|c|c|c|c|c|c|c|c|c|c|c|}
\hline Variáveis & Jan & Fev & Mar & Abr & Mai & Jun & Jul & Ago & Set & Out & Nov & Dez \\
\hline Q (L/s) & 55.500 & 52.800 & 50.300 & 36.500 & 31.400 & 33.500 & 26.600 & 21.500 & 26.900 & 30.200 & 33.000 & 43.900 \\
\hline c (mg/L) & 5 & 5 & 5 & 5 & 5 & 5 & 5 & 5 & 5 & 5 & 5 & 5 \\
\hline Cs (mg/s) & 277.500 & 264.000 & 251.500 & 182.500 & 157.000 & 167.500 & 133.000 & 107.500 & 134.500 & 151.000 & 165.000 & 219.500 \\
\hline $\mathrm{Ce}(\mathrm{mg} / \mathrm{s})^{*}$ & 2.245 & 2.245 & 2.245 & 2.245 & 2.245 & 2.245 & 2.245 & 2.245 & 2.245 & 2.245 & 2.245 & 2.245 \\
\hline$\sum \mathrm{Ce}(\mathrm{mg} / \mathrm{s})^{* *}$ & 60.407 & 60.407 & 60.407 & 60.407 & 60.407 & 60.407 & 60.407 & 60.407 & 60.407 & 60.407 & 60.407 & 60.407 \\
\hline ср (mg/L) & 60 & 60 & 60 & 60 & 60 & 60 & 60 & 60 & 60 & 60 & 60 & 60 \\
\hline $\mathrm{U}$ & 1 & 1 & 1 & 1 & 1 & 1 & 1 & 1 & 1 & 1 & 1 & 1 \\
\hline $\mathrm{I}_{\mathrm{c}}$ & 0,782 & 0,771 & 0,760 & 0,669 & 0,615 & 0,639 & 0,546 & 0,438 & 0,551 & 0,600 & 0,634 & 0,725 \\
\hline $\mathrm{K}_{\mathrm{c}} * * *$ & 179,15 & 185,42 & 191,73 & 239,22 & 265,40 & 253,80 & 297,58 & 344,66 & 295,29 & 272,63 & 256,45 & 210,61 \\
\hline Te (US\$/mês) & $6.703,19$ & $6.937,87$ & $7.174,00$ & $8.950,79$ & $9.930,29$ & $9.496,48$ & $11.134,61$ & $12.896,17$ & $11.048,78$ & $10.200,90$ & $9.595,53$ & $7.880,30$ \\
\hline
\end{tabular}

* Carga remanescente lançada pelo usuário, igual ao produto entre a vazão do efluente final (Qe) e a concentração do poluente nesse efluente (ce)

** Somatório das cargas poluidoras remanescentes no trecho em estudo (TABELA 27), descontados 20\% de autodepuração (valor arbitrado)

*** (US\$/mês)/(L/s)

\begin{tabular}{c|cc}
\hline Arrecadação em 2010 & \multicolumn{2}{|c}{ Cobrança Unitária } \\
\hline (US\$/ano) & (US\$/kgDBO/ano) & (US\$/hab/ano) \\
\hline $111.948,90$ & 1,581 & 1,91 \\
\hline
\end{tabular}


A simulação realizada para o ano de 2000 deixa patente quão onerosa seria a cobrança sobre lançamento de efluentes em situação de elevada escassez. Nesse cenário, a cobrança unitária média seria de US\$26,9/kgDBO, com variação entre US\$ 68,5/kgDBO em agosto a US\$ 2,20/kgDBO em janeiro. Se for considerada a cotação média do dólar em 2000 (R \$ 1,83), a cobrança unitária média no ano seria de $\mathrm{R}$ \$ 49,3/kgDBO, portanto, um valor 49 (quarenta e nove) vezes maior que o Preço Unitário Máximo (PUM), para lançamento de efluentes, da proposta de cobrança do Estado de São Paulo (R\$1,00/kgDBO).

A partir de 2005 verifica-se um decréscimo superior a 99\% na arrecadação, motivado pela introdução do sistema de tratamento de esgotos de Paulínia. Nesse cenário a cidade passa a requerer serviço ambiental bem menor. Os valores cobrados simulados para esse cenário seriam: cobrança unitária média de US\$1,62/kgDBO, variando entre US\$2,19/kgDBO em agosto a US\$ 1,14/kgDBO em janeiro.

A partir de 2010 o trecho experimentaria uma redução de 3,2\% na carga total remanescente e $40 \%$ na carga poluidora remanescente da cidade de Paulínia. Como resultado dessas variações, ter-se-ia uma diminuição de $41 \%$ no total arrecadado em relação a 2005. Em 2010, o valor da cobrança unitária média estaria em torno de US\$ 1,58/kgDBO, portanto, decréscimo de 2,2\% em relação à cobrança unitária média simulada para o ano de 2005.

\subsubsection{Cobrança sobre uso da água para geração de energia elétrica}

A geração de energia elétrica é um dos usos da água verificados no reservatório de Salto Grande. A empresa concessionária desse serviço é a CPFL - Geração de Energia S.A., proprietária da Usina Hidroelétrica de Americana com capacidade de geração de 30 MW (FIGURAS 6 e 7), localizada na Latitude Sul de 22 ${ }^{\circ}$ 42' e Longitude Oeste de $47^{\circ} 17^{\prime}$.

A usina de Americana funciona desde os anos 50. Um contrato de concessão para geração de energia elétrica regulamenta a outorga do direito de uso do potencial hidráulico do reservatório de Salto Grande - fornecida à concessionária supracitada. 


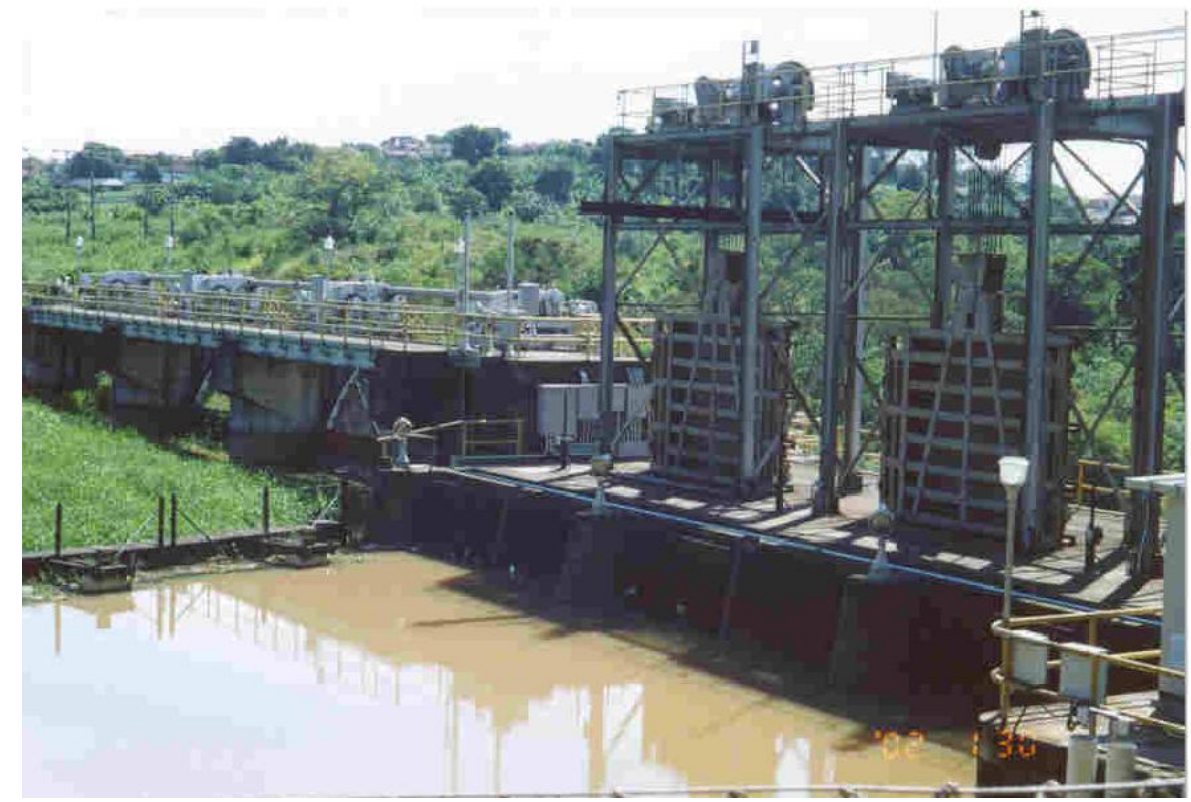

FIGURA 6 - Tomadas de água de Salto Grande para geração de energia (2001).

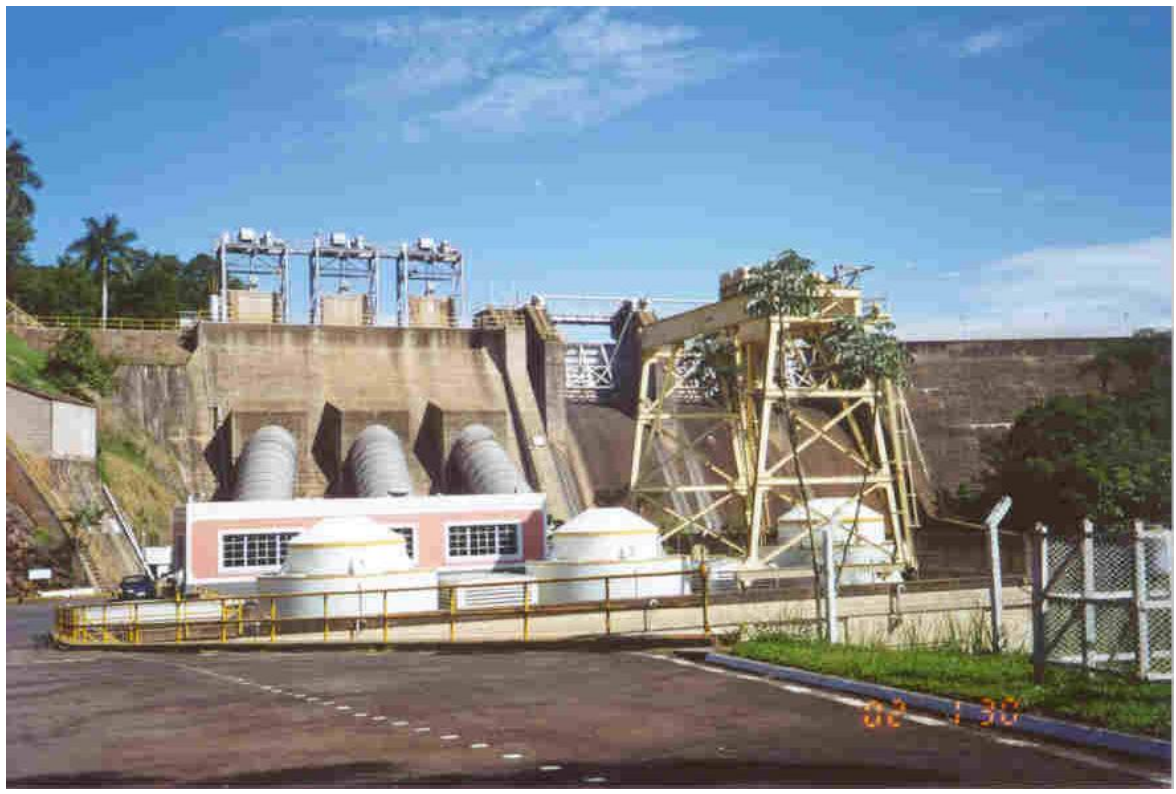

FIGURA 7 - Usina Hidroelétrica de Americana (2001). 
A concessão do direito de aproveitamento do potencial hidráulico é tarefa da Agência Nacional de Energia Elétrica (ANEEL), cabendo-lhe o papel de regular e fiscalizar a produção, transmissão, distribuição e comercialização de energia; e, no exercício de suas atribuições, promover a articulação com os Estados e o Distrito Federal, para aproveitamento energético dos cursos de água e compatibilização com a Política Nacional de Recursos Hídricos, de acordo com o disposto no art. $2^{\circ}$ da Lei Federal 9.427/96 que institui a ANEEL. Assim, cabe a essa Agência, entre outras atribuições: "promover as licitações destinadas à contratação de concessionárias de serviço público para produção, transmissão e distribuição de energia elétrica e para a outorga de concessão para aproveitamento de potenciais hidráulicos” (art. $3^{\circ}$, II).

Entretanto, para licitar a concessão ou autorizar o uso do potencial de energia hidráulica em corpo de água de domínio da União, a Agência Nacional de Energia Elétrica (ANEEL) promove, junto à Agência Nacional de Águas (ANA), a prévia obtenção de declaração de reserva de disponibilidade hídrica (Lei 9.984/00, art. $7^{\circ}$ ). Quando o potencial hidráulico se localiza em corpo de água de domínio dos Estados ou do Distrito Federal, a declaração de reserva de disponibilidade hídrica é obtida em articulação com a respectiva entidade gestora de recursos hídricos (art. $7^{\circ}, \S 1^{\circ}$ ).

Como o rio Atibaia pertence à bacia do rio Piracicaba, que é de domínio da União, ele fica sujeito ao disposto no caput do art. $7^{\circ}$ da Lei Federal 9.984/00, por meio da qual foi instituída a Agência Nacional de Águas (ANA). Como disposto no parágrafo segundo deste mesmo artigo: “a declaração de reserva de disponibilidade hídrica será transformada automaticamente, pelo respectivo poder outorgante, em outorga de direito de uso de recursos hídricos à instituição ou a empresa que receber da ANEEL a concessão ou a autorização de uso do potencial de energia hidráulica”.

A Lei 9.984/00 torna mais clara a maneira pela qual é possível obter outorga de direito de uso dos recursos hídricos para aproveitamento dos potenciais hidrelétricos, já prevista na Política Nacional de Recursos Hídricos (Lei 9.433/97, art. 12, IV). No entanto, em relação a aplicação da cobrança sobre este tipo de uso, a Lei 9.984/00 não faz referência alguma. Portanto, este tema carece de regulamentação na esfera federal, ou seja, existe lacuna no que se refere à cobrança sobre o uso da água para produção de energia elétrica. 
Atualmente, as hidrelétricas com capacidade de geração superior a $10.000 \mathrm{~kW}$ - exceto Pequenas Centrais Hidrelétricas (PCHs) - pagam compensação financeira aos Estados, Distrito Federal e Municípios pelo aproveitamento de recursos hídricos, para fins de geração de energia elétrica como disposto na Lei Federal 7.990/89. De acordo com o art. $17^{\circ}$ da Lei Federal 9.648/98, por meio do qual foi revogado o art. $2^{0}$ da Lei 7.990/89 e cuja redação foi mudada pelo art. $28^{\circ}$ da Lei Federal 9.984/00, a compensação financeira pela utilização de recursos hídricos é de 6,75\% sobre o valor da energia elétrica produzida. Essa compensação, para exploração de potencial hidráulico, é paga pelo titular da concessão ou autorização aos Estados, ao Distrito Federal e aos Municípios, em cujos territórios se localizarem instalações destinadas à produção de energia, ou que tenham áreas invadidas pelas águas dos respectivos reservatórios; e a órgãos da administração direta da União.

A compensação financeira é uma parcela de 6,75\% do produto entre: a energia gerada e a Tarifa Atualizada de Referência (TAR); a qual é fixada mensalmente pela ANEEL. Da parcela de 6,75\%, 6\% é destinado aos Estados, Municípios e órgãos da administração direta da União (Lei 9.984/00, art. 28 ${ }^{\circ}$, § $1^{\circ}$, I). A distribuição mensal desse montante é realizada da seguinte maneira: 45\% para os Estados; 45\% para os municípios; 4,4\% para o Ministério do Meio Ambiente; 3,6\% para o Ministério de Minas e Energia e 2\% para o ministério da Ciência e Tecnologia (Lei 9.984/00, art. $29^{\circ}$ ). A parcela restante de 0,75\% é destinada ao Ministério do Meio Ambiente.

Segundo MACHADO (2001), a exploração de recursos hídricos para fins de geração elétrica dá direito à participação nos resultados dessa exploração ou dá direito à compensação financeira por essa exploração, como previsto no art. $20^{\circ} \S 1^{\circ}$ da Constituição Federal. De acordo com artigo citado anteriormente, o autor enfatiza que as concessionárias devem pagar pela obtenção de resultados ou de lucros, e que essa obrigação não deve ser confundida com pagamento pelo simples uso da água.

Neste contexto, KELMAN (2000) argumenta que o setor elétrico é um usuário como outro qualquer e necessita pagar pela correspondente outorga de direito de uso da água. Para o referido autor, a compensação financeira visa tornar atraente, para os governos locais, a instalação de reservatórios e usinas hidrelétricas. Nesse caso o pagamento é realizado levando-se em conta o uso cessante da área ocupada pelo 
reservatório. Portanto, é preciso separar de maneira clara a cobrança sobre uso da água pelo setor elétrico da compensação financeira paga por esse setor.

Entretanto, cabe ressaltar que a necessidade de diferenciar os dois pagamentos não é seguida pela legislação federal. De acordo com a Lei Federal que instituiu a ANA (Lei 9.984/00, art. 28, § $1^{\circ}$, II), dos 6,75\% da energia produzida, referente à compensação financeira, uma parcela de 0,75\% é destinada ao Ministério do Meio Ambiente, para aplicação na implementação da Política Nacional de Recursos Hídricos e do Sistema Nacional de Gerenciamento de Recursos Hídricos, nos termos do art. $22^{\circ}$ da Lei 9.433/97, e do disposto na própria Lei 9.984/00. Além disso, o $§ 2^{\circ}$ estabelece que essa parcela constitui pagamento pelo uso de recursos hídricos a ser aplicada nos termos do art. $22^{\circ}$ da Lei 9.433/97.

Percebe-se, assim, que foi incorporada à compensação financeira uma parcela relativa à cobrança sobre uso da água, a qual incide sobre a quantidade de energia produzida e não à de água efetivamente usada na produção energética. Dessa forma, uma hidrelétrica que possui eficiência baixa pagaria menos por um volume maior de água utilizada, uma vez que seria necessária mais água para produzir uma mesma quantidade de energia.

A partir do pressuposto que os aproveitamentos dos potenciais hidrelétricos estão sujeitos à outorga de direito de uso dos recursos hídricos (Lei 9.433/97, art. 12, IV), e que a cobrança está diretamente vinculada a essa outorga (Lei 9.433/97, art. 20), faz-se necessária a formulação e aplicação de metodologia de cobrança na qual o setor elétrico seja incorporado como outro qualquer usuário - mesmo que neste caso o uso seja considerado como não consuntivo.

Nesse contexto, KELMAN (2000) descreve duas situações que ocorrem quando da consideração do setor elétrico em um processo de implantação da cobrança sobre os usos da água. Ao olhar para montante, vislumbram-se conflitos de interesses e a disputa pelo uso da água - mesmo que seja disponibilizada em quantidades maiores. Muitos desses conflitos são devidos ao interesse do produtor de energia em estocar as águas para uso futuro ou manter um nível mínimo de queda. Nessas situações, faz-se necessário um sistema bem definido de outorgas, por meio do qual sejam mescladas outorgas de uso consuntivo e uso não consuntivo, como a geração de energia elétrica. Ressalta-se, ainda, a necessidade de incorporar ao sistema a variabilidade climática. 
Olhando para jusante, o proprietário de uma usina hidrelétrica, ao mudar o regime fluvial por meio de um reservatório de regularização, passa a ser um usuário desse trecho de rio, tanto em termos quantitativos como qualitativos. Neste caso, nos meses em que a depleção fosse maior que a vazão natural do corpo de água, a operação da usina causaria uma externalidade positiva aos usuários de jusante, assim, seria razoável considerar o ressarcimento do setor elétrico pela maior disponibilidade de água a jusante. Em períodos de acumulação, a situação é oposta. Nesse caso, a usina disponibilizaria aos usuários de jusante menos água do que a vazão natural afluente ao reservatório. Para esses usuários a geração de energia seria considerada como uso consuntivo que geraria externalidades negativas e, portanto, passível de aplicação da cobrança. Cabe destacar que usinas hidrelétricas operadas a fio de água não alteram o regime fluvial; portanto, nesses casos a usina não seria um usuário dos trechos de jusante.

Além dos aspectos quantitativos envolvidos nas situações antes descritas, cabe ressaltar os relativos à questão qualitativa. Toma-se como exemplo o reservatório de Salto Grande, em processo de eutrofização, onde o acúmulo de água favorece a retenção e oxidação de diversas substâncias poluentes. De acordo com TEIXEIRA (2000), essa retenção para o parâmetro DBO chega a 51\% da carga afluente ao reservatório. Neste caso a usina seria usuário qualitativo do trecho de jusante, por vezes causando-lhe melhoria na qualidade da água, fato que poderia ser considerado externalidade positiva.

Os aspectos e situações descritos anteriormente são considerados na aplicação da metodologia de cobrança sobre uso da água do reservatório de Salto Grande para geração de energia elétrica. Como a usina não possui uma regra operativa definida, optou-se por utilizar o histórico de vazões efluentes, comparando-o com o histórico de vazões afluentes ao reservatório.

Esse procedimento permitiu observar aqueles meses em que ocorre depleção ou acúmulo de água - períodos em que a aplicação da cobrança é diferenciada. $\mathrm{Na}$ TABELA 40 e FIGURA 8 são apresentas as vazões médias mensais afluentes e efluentes ao reservatório de Salto Grande. Diferente do cenário de vazões usado nas simulações anteriores (1975 a 1996), na simulação da cobrança para o setor elétrico foi utilizada uma série de 1979 a 1996, por falta de dados entre 1975 e 1978. 
TABELA 40 - Vazões médias mensais afluentes e efluentes ao reservatório de Salto Grande.

\begin{tabular}{c|c|c}
\hline Mês & Vazão Afluente $\left(\mathrm{m}^{3} / \mathrm{s}\right)$ & Vazão Efluente $\left(\mathrm{m}^{3} / \mathrm{s}\right)$ \\
\hline Janeiro & 57,0 & 57,9 \\
Fevereiro & 52,5 & 56,3 \\
Março & 52,3 & 54,6 \\
Abril & 37,6 & 39,5 \\
Maio & 32,6 & 32,0 \\
Junho & 33,6 & 32,0 \\
Julho & 25,9 & 24,4 \\
Agosto & 21,9 & 21,5 \\
Setembro & 26,8 & 26,1 \\
Outubro & 31,1 & 30,2 \\
Novembro & 31,8 & 31,8 \\
Dezembro & 41,7 & 41,8 \\
\hline
\end{tabular}

Fonte: CPFL - Geração de Energia S.A.

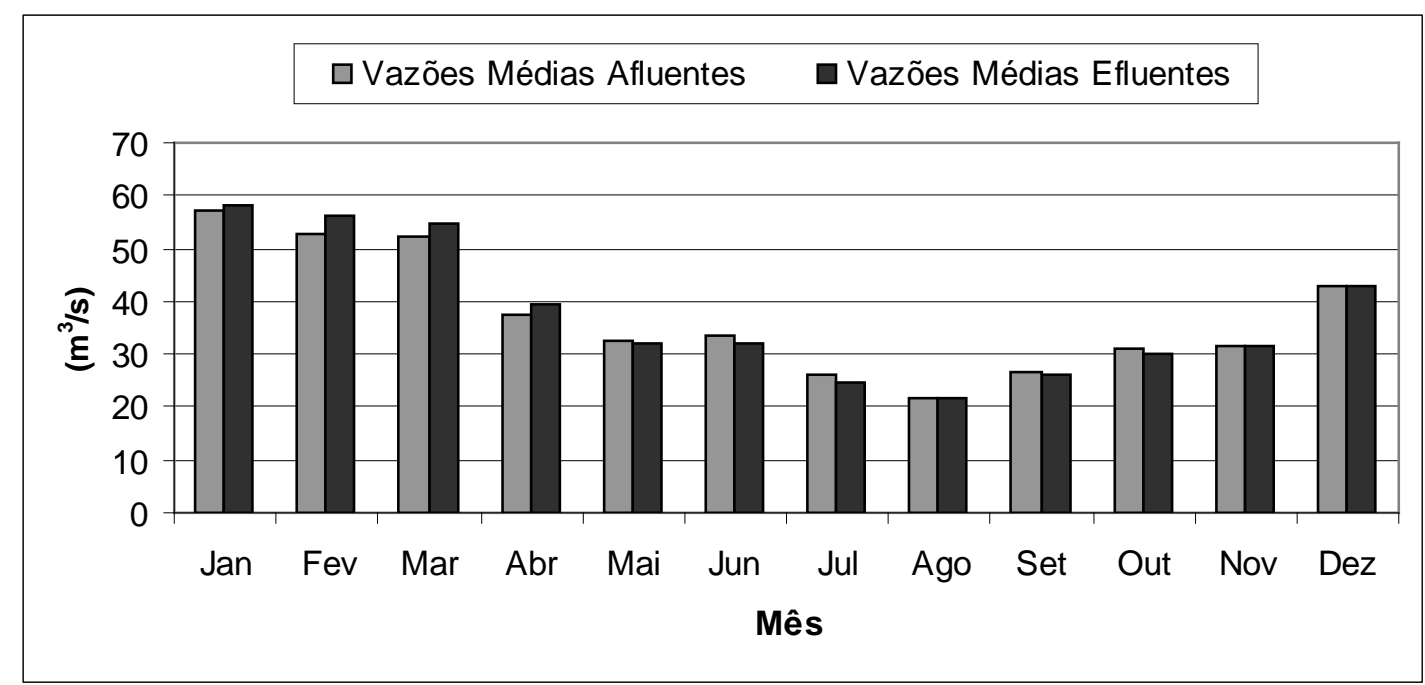

FIGURA 8 - Gráfico de vazões médias mensais afluentes e efluentes ao reservatório de Salto Grande.

De acordo com os dados de vazão, entre dezembro e abril ocorreria depleção e, entre maio e outubro, acumulação no reservatório. Em novembro a usina funcionaria a fio de água, portanto, o regime fluvial do rio Atibaia não mudaria nesse período. 
A aplicação da metodologia de cobrança sobre uso da água para geração de energia considera os três períodos distintos. De dezembro a abril a vazão turbinada é maior que a vazão natural do rio, portanto, nesses meses a usina utilizaria um volume excedente de água - acumulada durante o período de maio a outubro. Considerando ainda o mesmo período, a Usina descarregaria, para jusante, um excedente de vazão, com qualidade melhor que a vazão afluente. No caso do parâmetro poluidor utilizado (DBO), a redução na carga poluidora chega a 51\% em Salto Grande.

Entre dezembro e abril, a usina disponibilizaria, aos usuários de jusante, mais que a vazão natural do rio, portanto, causaria aumento da capacidade de oferta e depuração desse trecho. Nesse período, a usina causaria externalidade positiva para esses usuários, portanto, poderia ser ressarcida pelo benefício causado. Todavia, isso seria válido apenas se, o crescimento na oferta, fosse acompanhado pelo da demanda.

Assim, procura-se calcular a oferta excedente de vazão. Nesse período a Usina estabelece recarga de água no rio. Portanto, o único ajuste necessário à metodologia de cobrança usada é considerar, no período de depleção, valores negativos de vazão consumida (Qcon), pois nesse período a usina é oferecedora de água para usuários de jusante e não consumidora. Nesse caso, é como se os usuários de jusante pagassem à Usina a oferta do excedente de água - por isso valores negativos de cobrança $\left(\mathrm{T}_{\mathrm{c}}\right)$.

No período de maio a outubro ocorreria acumulo de água no reservatório. Para usuários de jusante, nesse período, a geração de energia tornar-se-ia uso consuntivo. Nesse caso o sistema de cobrança funcionaria como se fosse sobre captação comum. Portanto, o produtor deveria pagar pela reserva de água, pois causaria externalidade negativa a usuários de jusante ou ao ambiente - em contrapartida de um benefício privado (a geração de energia elétrica). Em outubro, como a usina trabalharia a fio de água, a cobrança seria nula, pois não haveria mudança no regime fluvial do rio.

Nas TABELAS 41, 42 e 43 são apresentados os resultados da cobrança sobre a geração de energia no reservatório de Salto Grande, simulada para os anos de 2000, 2005 e 2010, respectivamente. Nas tabelas estão descritas as considerações feitas na adaptação da metodologia de SOUZA (1995), para aplicação da cobrança sobre a geração de energia. A primeira mudança está no fato de a cobrança ser negativa em meses de depleção (receita), positiva em meses de acumulo de água (despesa) e nula no mês em que a usina trabalhe a fio de água. 
TABELA 41 - Cobrança sobre uso da água para geração de energia elétrica no reservatório de Salto Grande em 2000.

\begin{tabular}{|c|c|c|c|c|c|c|c|c|c|c|c|c|}
\hline Variáveis & Jan & Fev & Mar & Abr & Mai & Jun & Jul & Ago & Set & Out & Nov & Dez \\
\hline $\mathrm{Q}(\mathrm{L} / \mathrm{s})^{*}$ & 57.000 & 52.500 & 52.300 & 37.600 & 32.600 & 33.600 & 25.900 & 21.600 & 26.800 & 31.100 & 31.800 & 41.700 \\
\hline c (mg/L) & 5 & 5 & 5 & 5 & 5 & 5 & 5 & 5 & 5 & 5 & 5 & 5 \\
\hline Cs (mg/s) & 289.500 & 281.500 & 273.000 & 197.500 & 163.000 & 168.000 & 129.500 & 108.000 & 134.000 & 155.500 & 159.000 & 214.000 \\
\hline$\sum \mathrm{Ce}(\mathrm{mg} / \mathrm{s})^{* *}$ & 79.539 & 79.539 & 79.539 & 79.539 & 79.539 & 79.539 & 79.539 & 79.539 & 79.539 & 79.539 & 79.539 & 79.539 \\
\hline Qcon (L/s)*** & -900 & -3.800 & -2.300 & -1.900 & 600 & 1.600 & 1.500 & 400 & 700 & 900 & 0 & -100 \\
\hline ср (mg/L) & 60 & 60 & 60 & 60 & 60 & 60 & 60 & 60 & 60 & 60 & 60 & 60 \\
\hline$S$ & 1 & 1 & 1 & 1 & 1 & 1 & 1 & 1 & 1 & 1 & 1 & 1 \\
\hline $\mathrm{I}_{1}$ & 0,725 & 0,717 & 0,709 & 0,597 & 0,512 & 0,527 & 0,386 & 0,264 & 0,406 & 0,488 & 0,500 & 0,628 \\
\hline $\mathrm{K}_{1} * * * *$ & 210,37 & 214,48 & 219,06 & 273,89 & 312,69 & 306,23 & 366,48 & 415,39 & 357,94 & 323,02 & 318,09 & 259,14 \\
\hline $\mathrm{I}_{2}$ & 0,721 & 0,697 & 0,696 & 0,577 & 0,503 & 0,503 & 0,348 & 0,250 & 0,391 & 0,473 & 0,500 & 0,627 \\
\hline $\mathrm{K}_{2} * * * *$ & 212,65 & 225,07 & 225,66 & 283,37 & 316,72 & 316,72 & 381,88 & 420,78 & 364,54 & 329,63 & 318,09 & 259,56 \\
\hline$\left(\mathrm{K}_{2}-\mathrm{K}_{1}\right)^{* * * *}$ & 2,29 & 10,59 & 6,60 & 9,48 & 4,03 & 10,48 & 15,40 & 5,39 & 6,60 & 6,61 & 0,00 & 0,42 \\
\hline $\mathrm{T}_{\mathrm{c}}$ (US\$/mês) & $-3.030,88$ & $-14.045,25$ & $-8.752,96$ & $-12.562,57$ & $5.347,29$ & $13.899,38$ & $20.416,49$ & $7.148,18$ & $8.745,06$ & $8.765,01$ & 0,00 & $-577,56$ \\
\hline
\end{tabular}

* Vazões afluentes ao reservatório.

** Somatório das cargas poluidoras remanescentes a jusante da Usina Hidrelétrica de Americana (considerando que o reservatório retém 51\% da carga de DBO)

*** De dezembro a abril: vazão excedente turbinada (diferença entre a vazão efluente e a afluente); de maio a outubro: vazão acumulada (diferença entre a vazão afluente e a efluente); em novembro a usina trabalha a fio de água, portanto, não existe depleção nem acumulo **** (US\$/mês)/(L/s)

Os valores negativos de $T_{c}$ correspondem às receitas e os demais às despesas

\begin{tabular}{c}
\hline Arrecadação em 2000 \\
\hline (US\$/ano) \\
\hline $25.352,18$ \\
\hline
\end{tabular}


TABELA 42 - Cobrança sobre uso da água para geração de energia elétrica no reservatório de Salto Grande em 2005.

\begin{tabular}{|c|c|c|c|c|c|c|c|c|c|c|c|c|}
\hline Variáveis & Jan & Fev & Mar & Abr & Mai & Jun & Jul & Ago & Set & Out & Nov & Dez \\
\hline $\mathrm{Q}(\mathrm{L} / \mathrm{s})^{*}$ & 57.000 & 52.500 & 52.300 & 37.600 & 32.600 & 33.600 & 25.900 & 21.600 & 26.800 & 31.100 & 31.800 & 41.700 \\
\hline c (mg/L) & 5 & 5 & 5 & 5 & 5 & 5 & 5 & 5 & 5 & 5 & 5 & 5 \\
\hline Cs (mg/s) & 289.500 & 281.500 & 273.000 & 197.500 & 163.000 & 168.000 & 129.500 & 108.000 & 134.000 & 155.500 & 159.000 & 214.000 \\
\hline$\sum \mathrm{Ce}(\mathrm{mg} / \mathrm{s})^{* *}$ & 30.571 & 30.571 & 30.571 & 30.571 & 30.571 & 30.571 & 30.571 & 30.571 & 30.571 & 30.571 & 30.571 & 30.571 \\
\hline Qcon $(\mathrm{L} / \mathrm{s})^{* * *}$ & -900 & -3.800 & -2.300 & -1.900 & 600 & 1.600 & 1.500 & 400 & 700 & 900 & 0 & -100 \\
\hline ср (mg/L) & 60 & 60 & 60 & 60 & 60 & 60 & 60 & 60 & 60 & 60 & 60 & 60 \\
\hline S & 1 & 1 & 1 & 1 & 1 & 1 & 1 & 1 & 1 & 1 & 1 & 1 \\
\hline $\mathrm{I}_{1}$ & 0,894 & 0,891 & 0,888 & 0,845 & 0,812 & 0,818 & 0,764 & 0,717 & 0,772 & 0,803 & 0,808 & 0,857 \\
\hline $\mathrm{K}_{1} * * * *$ & 108,75 & 110,88 & 113,25 & 141,59 & 161,65 & 158,31 & 189,46 & 214,74 & 185,05 & 166,99 & 164,44 & 133,97 \\
\hline $\mathrm{I}_{2}$ & 0,893 & 0,884 & 0,883 & 0,837 & 0,809 & 0,809 & 0,749 & 0,712 & 0,766 & 0,798 & 0,808 & 0,857 \\
\hline $\mathrm{K}_{2} * * * *$ & 109,94 & 116,35 & 116,66 & 146,49 & 163,73 & 163,73 & 197,42 & 217,53 & 188,46 & 170,41 & 164,44 & 134,18 \\
\hline$\left(\mathrm{K}_{2}-\mathrm{K}_{1}\right)^{* * * *}$ & 1,18 & 5,48 & 3,41 & 4,90 & 2,09 & 5,42 & 7,96 & 2,79 & 3,41 & 3,42 & 0,00 & 0,22 \\
\hline $\mathrm{T}_{\mathrm{c}}$ (US\$/mês) & $-602,23$ & $-2.790,76$ & $-1.739,19$ & $-2.496,15$ & $1.062,49$ & $2.761,77$ & $4.056,71$ & $1.420,33$ & $1.737,62$ & $1.741,59$ & 0,00 & $-114,76$ \\
\hline
\end{tabular}

* Vazões afluentes ao reservatório.

** Somatório das cargas poluidoras remanescentes a jusante da Usina Hidrelétrica de Americana (considerando que o reservatório retém 51\% da carga de DBO)

*** De dezembro a abril: vazão excedente turbinada (diferença entre a vazão efluente e a afluente); de maio a outubro: vazão acumulada (diferença entre a vazão afluente e a efluente); em novembro a usina trabalha a fio de água, portanto, não existe depleção nem acumulo **** (US\$/mês)/(L/s)

Os valores negativos de $T_{c}$ correspondem às receitas e os demais às despesas

\begin{tabular}{c}
\hline Arrecadação em 2005 \\
\hline (US\$/ano) \\
\hline $5.037,42$ \\
\hline
\end{tabular}


TABELA 43 - Cobrança sobre uso da água para geração de energia elétrica no reservatório de Salto Grande em 2010.

\begin{tabular}{|c|c|c|c|c|c|c|c|c|c|c|c|c|}
\hline Variáveis & Jan & Fev & Mar & Abr & Mai & Jun & Jul & Ago & Set & Out & Nov & Dez \\
\hline $\mathrm{Q}(\mathrm{L} / \mathrm{s})^{*}$ & 57.000 & 52.500 & 52.300 & 37.600 & 32.600 & 33.600 & 25.900 & 21.600 & 26.800 & 31.100 & 31.800 & 41.700 \\
\hline с (mg/L) & 5 & 5 & 5 & 5 & 5 & 5 & 5 & 5 & 5 & 5 & 5 & 5 \\
\hline Cs (mg/s) & 289.500 & 281.500 & 273.000 & 197.500 & 163.000 & 168.000 & 129.500 & 108.000 & 134.000 & 155.500 & 159.000 & 214.000 \\
\hline$\sum \mathrm{Ce}(\mathrm{mg} / \mathrm{s})^{* *}$ & 29.600 & 29.600 & 29.600 & 29.600 & 29.600 & 29.600 & 29.600 & 29.600 & 29.600 & 29.600 & 29.600 & 29.600 \\
\hline Qcon $(\mathrm{L} / \mathrm{s})^{* * *}$ & -900 & -3.800 & -2.300 & -1.900 & 600 & 1.600 & 1.500 & 400 & 700 & 900 & 0 & -100 \\
\hline cp (mg/L) & 60 & 60 & 60 & 60 & 60 & 60 & 60 & 60 & 60 & 60 & 60 & 60 \\
\hline$S$ & 1 & 1 & 1 & 1 & 1 & 1 & 1 & 1 & 1 & 1 & 1 & 1 \\
\hline $\mathrm{I}_{1}$ & 0,898 & 0,895 & 0,892 & 0,850 & 0,818 & 0,824 & 0,771 & 0,726 & 0,779 & 0,810 & 0,814 & 0,862 \\
\hline $\mathrm{K}_{1} * * * *$ & 106,36 & 108,43 & 110,75 & 138,47 & 158,09 & 154,83 & 185,29 & 210,01 & 180,97 & 163,31 & 160,82 & 131,02 \\
\hline $\mathrm{I}_{2}$ & 0,896 & 0,887 & 0,887 & 0,843 & 0,815 & 0,815 & 0,757 & 0,721 & 0,773 & 0,804 & 0,814 & 0,861 \\
\hline $\mathrm{K}_{2} * * * *$ & 107,51 & 113,79 & 114,09 & 143,26 & 160,13 & 160,13 & 193,07 & 212,74 & 184,31 & 166,65 & 160,82 & 131,23 \\
\hline$\left(\mathrm{K}_{2}-\mathrm{K}_{1}\right)^{* * * *}$ & 1,16 & 5,36 & 3,34 & 4,79 & 2,04 & 5,30 & 7,79 & 2,73 & 3,34 & 3,34 & 0,00 & 0,21 \\
\hline $\mathrm{T}_{\mathrm{c}}$ (US\$/mês) & $-570,26$ & $-2.642,60$ & $-1.646,86$ & $-2.363,64$ & $1.006,09$ & $2.615,16$ & $3.841,35$ & $1.344,93$ & $1.645,38$ & $1.649,13$ & 0,00 & $-108,67$ \\
\hline
\end{tabular}

* Vazões afluentes ao reservatório.

** Somatório das cargas poluidoras remanescentes a jusante da Usina Hidrelétrica de Americana (considerando que o reservatório retém 51\% da carga de DBO)

*** De dezembro a abril: vazão excedente turbinada (diferença entre a vazão efluente e a afluente); de maio a outubro: vazão acumulada (diferença entre a vazão afluente e a efluente); em novembro a usina trabalha a fio de água, portanto, não existe depleção nem acumulo **** (US\$/mês)/(L/s)

Os valores negativos de $T_{c}$ correspondem às receitas e os demais às despesas

\begin{tabular}{c}
\hline Arrecadação em 2010 \\
\hline (US\$/ano) \\
\hline $4.770,00$ \\
\hline
\end{tabular}


Nas simulações da cobrança sobre uso da água para geração de energia, o valor a ser cobrado é resultado do balanço entre as receitas obtidas em períodos de depleção e as despesas em períodos de acúmulo de água no reservatório. No caso da depleção, ao favorecer usuários de jusante por meio de uma vazão regularizada maior que a vazão natural do corpo de água, a usina seria ressarcida em cerca de US\$ 38.969,22 em 2000. Nos meses em que ocorre acúmulo de água, a usina pagaria pela vazão acumulada nesse período o valor de US\$ 64.321,41. A diferença entre esses dois valores corresponde ao total que seria cobrado da usina em 2000 - cerca de US\$ 25.352,18.

O mesmo raciocínio é válido para outras simulações realizadas para os anos de 2005 e 2010. Vale ressaltar que a importância das simulações está relacionada à questão metodológica, e no quanto os diferentes graus de escassez relativa afetam no valor a ser cobrado. Os resultados apresentados são apenas um indicativo que serve à comparação entre cenários simulados.

Percebe-se que o valor cobrado em 2005 sofreria redução em cerca de $80 \%$ em relação ao do ano 2000. Como mencionado, essa redução é causada pelo decréscimo na carga poluente lançada no trecho, a qual sofre uma redução ainda maior pelo fato de o reservatório reter cerca de 51\% da carga orgânica afluente. Em 2010 a redução no valor cobrado seria de 81,2\% em relação ao cenário de 2000 . 


\section{Conclusões}

Na prática, os sistemas de cobrança sobre usos da água estudados procuram atender a uma gama de objetivos, entre os quais podem ser citados: recuperação de custos administrativos de gestão das águas; operação e manutenção da infra-estrutura hídrica; fonte de arrecadação para investimentos em infra-estrutura; e a mudança de comportamento dos usuários em relação à utilização da água. Cabe destacar que este último deveria ser objetivo precípuo da implementação dos instrumentos econômicos de gestão dos recursos hídricos.

Entretanto, em alguns casos analisados este objetivo é relegado a segundo plano, e invariavelmente o valor cobrado fica abaixo do custo marginal social de uso das águas, ou seja, não reflete as externalidades causadas pelo uso irracional ou inadequado desse indispensável recurso natural.

Portanto, há casos em que a aplicação dos instrumentos econômicos é dotada de caráter corretivo: serve como fonte de arrecadação para investimentos na melhoria do ambiente. Assim, o caráter de prevenção sobre causas da escassez ou da poluição - como incentivo ao uso adequado das águas - recebe pouca atenção. Ao final do processo, fica descaracterizada a aplicação dos instrumentos econômicos de gestão, porque a arrecadação se torna finalidade, quando deveria ser conseqüência inerente ao emprego do instrumento.

A cobrança deve atuar como mecanismo regulador da apropriação dos recursos hídricos. Para isso, é fundamental considerar o preceito da escassez relativa, ou seja, as especificidades locais. A menos disso, a cobrança pode tornar-se obrigação de respeito às regras de utilização das águas, pois, em muitas situações, o valor cobrado não retrata o real valor do recurso natural e, portanto, não induz ao comportamento racional dos usuários. Desta maneira, a cobrança, não é senão mais um instrumento de comando e controle. 
Nas simulações realizadas, os valores cobrados ao longo do tempo refletem as distintas situações de escassez relativa, seja ela devida à sazonalidade da oferta de água ou à variação das cargas poluidoras remanescentes no ecossistema de estudo. Assim, há grandes variações nos valores cobrados em um mesmo ano e entre os horizontes de um cenário. Percebe-se que a variação sazonal da cobrança pode, por exemplo, incentivar que maiores descargas sejam realizadas em períodos de grande oferta de vazão.

O uso de recurso hídrico para geração de energia elétrica deve ser considerado como qualquer outro na implementação da cobrança sobre usos da água. Apesar de esse uso ser considerado não consuntivo - fato que poderia justificar isenção da cobrança - na realidade ele causa, em vários momentos, externalidades negativas, principalmente, a usuários de jusante.

Cabe observar que, se aplicada como instrumento de gestão, a cobrança pode se constituir em eficiente mecanismo de indução de uso adequado da água e elemento importante na relação entre a política de uso do solo e a política de águas. Trata-se, portanto, de instrumento poderoso, pois trabalha com linguagem reconhecidamente eficiente aos agentes econômicos, isto é, o dinheiro, objeto maior das organizações mercantis. 


\section{Referências Bibliográficas}

ALMEIDA, L. T. (1998). Política ambiental: uma análise econômica. Campinas, Paribus/São Paulo, Fundação Editora da Unesp.

ALVARES DA SILVA, U. P.; BEZERRA, H. E. R. (2001). A descentralização da gestão dos recursos hídricos no Ceará: a experiência da gerência da bacia hidrográfica do Curu (CD ROM). In: SIMPÓSIO BRASILEIRO DE RECURSOS HÍDRICOS, 14 e SIMPÓSIO DE HIDRÁULICA E RECURSOS HÍDRICOS DOS PAÍSES DE LINGUA OFICIAL PORTUGUESA, 5., Aracaju, 2001. Anais. Porto Alegre, ABRH.

ARAÚJO, J. C. (1996). Estudos de tarifa d’água e hidrológicos. Fortaleza. Relatório técnico CNPq/COGERH.

ARAUUJO, J. C.; SOUZA, M. P. (1999). Avaliação do sistema tarifário de água bruta no Ceará (CD ROM). In: SIMPÓSIO BRASILEIRO DE RECURSOS HÍDRICOS, 13., Belo Horizonte, 1999. Anais. Porto Alegre, ABRH.

ASAD, M.; AZEVEDO, L. G. T.; KEMPER, K. E.; SIMPSON, L. D. (1999). Management of water resources: bulk water pricing in Brazil. World Bank Technical Paper 432. Washington, D.C., The World Bank.

AZEVEDO, L. G. T.; BALTAR, A. M.; FREITAS, P. (2000). A experiência internacional. In: THAME, A. C. M. et al. A cobrança pelo uso da água. São Paulo, IQUAL. p.19-27.

BARRAQUÉ, B. (dir) (1995). As políticas de água na Europa. Lisboa, Instituto Piaget. 
BARRAQUÉ, B. (1999a). Water intitutions and management in France. In: SEMANA INTERNACIONAL DE ESTUDOS SOBRE GESTÃO DE RECURSOS HÍDRICOS. Foz do Iguaçu, ABRH.

BARRAQUÉ, B. (1999b). Assessing the efficiency of economic instruments: the case of the french agences de l'eau. In: SEMANA INTERNACIONAL DE ESTUDOS SOBRE GESTÃO DE RECURSOS HÍDRICOS. Foz do Iguaçu, ABRH.

BARTH, F. T. (2000). A cobrança como suporte financeiro à política estadual de recursos hídricos. In: THAME, A. C. M. et al. A cobrança pelo uso da água. São Paulo, IQUAL. p.135-152.

BAUER, C. J. (1997). Bringing water markets down to earth: the political economy of water rights in Chile, 1976-95. World Development. v. 25, n. 05, p.639-656.

CAIRNCROSS, F. (1992). Meio ambiente: custos e benefícios. São Paulo, Nobel.

CÁNEPA, E. M.; PEREIRA, J. S.; LANNA, A. E. L. (1999). A política de recursos hídricos e o princípio usuário-pagador (PUP). Revista Brasileira de Recursos Hídricos. v. 04, n. 01, p. 103-117.

CEPAL (2000). Instrumentos económicos para el control de la contaminación del agua: condiciones y casos de aplicación. Versão Preliminar.

CETEC (2000). Relatório de situação dos recursos hídricos das bacias hidrográficas dos Rios Piracicaba, Capivari e Jundiaí - “Relatório Zero”. São Paulo.

CETESB (2001). Relatório de qualidade das águas interiores do Estado de São Paulo 2000. São Paulo.

COMITÊ COORDENADOR DO PLANO ESTADUAL DE RECUROS HÍDRICOS - CORHI (1997). Simulação da cobrança pelo uso da água. Versão preliminar de 31/07/97. São Paulo. 
CONEJO, J. G. L. (2000). O sistema paulista de gerenciamento de recursos hídricos e a cobrança pelo uso da água. In: THAME, A. C. M. et al. A cobrança pelo uso da água. São Paulo, IQUAL. p.127-134.

COPLAENGE - PROJETOS DE ENGENHARIA LTDA (2000). Plano de bacia hidrográfica 2000 - 2003/UGRHI - PCJ. Relatório Final. São Paulo. http://www.comitepcj.sp.gov.br

DEPARTMENT OF THE ENVIRONMENT, TRANSPORT AND THE REGIONS - DETR (1999). Economic instruments for water pollution discharges. United Kingdom. http://www.defra.gov.uk/environment/wpd/index.htm

DIRECCION GENERAL DE AGUAS (1999). Política Nacional de Recursos Hídricos. Chile. http://www.dga.cl

EASTER, K. W.; HEARNE, R. (1995). Water markets and decentralized water resources management: international problems and opportunities. Water Resources Bulletin, v.31, n.01, p.9-20, fev.

ECOTEC RESEARCH \& CONSULTING (2001). Study on the economic and environmental implications of the use of environmental taxes and charges in the European Union and its member States. Final Report, Cap.7. United Kingdom. http://europa.eu.int/comm/environment/enveco/taxation/environmental_taxes.htm

ENVIRONMENT AGENCY (2000). Abstraction charges 2000 - 2001. United Kingdom. /folder/

FEDERAL MINISTRY FOR THE ENVIRONMENT, NATURE CONSERVATION AND NUCLEAR SAFETY (1998). Environmental policy - water resources management in Germany. Bonn.

FERREIRA, C. M. L. (2000). Estudo de uma área alagada do Rio Atibaia visando a elaboração de proposta de manejo para melhoria da qualidade da água no reservatório de Salto Grande (Americana, SP). São Carlos. 145p. Tese (Doutorado) - Escola de Engenharia São Carlos, Universidade de São Paulo. 
GARRIDO, R. (2000). Considerações sobre a formação de preços para a cobrança pelo uso da água no Brasil. In: THAME, A. C. M. et al. A cobrança pelo uso da água. São Paulo, IQUAL. p.57-92.

GLEICK, P. H. (2000). The changing water paradigm - a look at twenty-first century water resources development. Water International, v.25, n.01, p.127-138, mar.

JAMES, D. (1997). Environmental incentives: australian experience with economic instruments for environmental Management. Canberra, Environment Australia.

KELMAN, J. (2000). Outorga e cobrança de recursos hídricos. In: THAME, A. C. M. et al. A cobrança pelo uso da água. São Paulo, IQUAL. p. 93-113

KEMPER, K. E. (2001). The role of institutional arrangements for more efficient water resources use and allocation. Water Science and Technology. v. 43, n.04, p. 111-117.

KRAEMER, R. A. (1999). Water management and policy in Germany. In: SEMANA INTERNACIONAL DE ESTUDOS SOBRE GESTÃO DE RECURSOS HÍDRICOS. Foz do Iguaçu, ABRH.

LANNA, A. E. L. (1991). Aspectos econômicos e financeiros da cobrança pelo uso e poluição da água. Revista Brasileira de Engenharia-Caderno de Recursos Hídricos. v.8, n.2.

LANNA, A. E. L. (1996). Instrumentos econômicos de gestão ambiental. Texto colhido da Internet. Porto Alegre, IPH-UFRGS.

LANNA, A. E. L. (1999). Hidroeconomia. In: Águas doces do Brasil: capital ecológico, uso e conservação. São Paulo, Escrituras. Cap.16, p.533-564.

LANNA, A. E. L. (2000). A inserção da gestão das águas na gestão ambiental. In: Interfaces da gestão de recursos hídricos: desafios da lei de águas de 1997. Brasília, SRH. p.75-109. 
LEITE, M. A. (1998). Variação espacial e temporal da taxa de sedimentação no reservatório de Salto Grande (Americana-SP) e sua influência sobre as características limnológicas do sistema. São Carlos. 167p. Dissertação (Mestrado) - Escola de Engenharia de São Carlos, Universidade de São Paulo.

LOUCKS, D. P. (2000). Sustainable water resources management. Water International, v.25, n.01, p.3-10, mar.

MACEDO H. P. (2000). A experiência do Estado do Ceará. In: THAME, A. C. M. et al. A cobrança pelo uso da água. São Paulo, IQUAL. p.29-32.

MACHADO P. A. L. (2001). Direito ambiental brasileiro. São Paulo, Malheiros.

MALANO, M. H.; BRYANT, M. J.; TURRAL, H. N. (1999). Management of water resources - Can Australian experiences be transferred to Vietnam? Water International, v. 24, n. 4, p. 307-315, dez.

MARTINEZ JUNIOR., F. (1997). Aplicação de instrumentos econômicos à gestão ambiental - introdução da cobrança pela utilização dos recursos hídricos no Estado de São Paulo. São Paulo. 253p. Tese (Doutorado) - Escola Politécnica, Universidade de São Paulo.

MENDES, F. E.; SEROA DA MOTTA, R. (1997). Instrumentos econômicos para o controle ambiental do ar e da água: uma resenha da experiência internacional. Texto para discussão $\mathrm{n}^{0}$ 479. Rio de Janeiro, IPEA.

MÉXICO. Leis, etc. (2002). Decreto por el que se Reforma, Adiciona y Deroga diversas disposiciones de la Ley Federal de Derechos de 31 de diciembre de 2001. México, DF.

MORAES, J. M.; GENOVEZ, A. M.; MORTATTI, J.; BALLESTER, M. V.; KRUSCH, A. V.; MARTINELLI, L. A.; VICTORIA, R. L. (1997). Análise de intervenção das séries temporais de vazão dos principais rios da bacia do rio Piracicaba. Revista Brasileira de Recursos Hídricos. v. 2, n. 2, p. 65-79. 
MOSTERT, E. (1999). Models for river basin management - experiences from the eurowater countries. In: SEMANA INTERNACIONAL DE ESTUDOS SOBRE GESTÃO DE RECURSOS HÍDRICOS. Foz do Iguaçu, ABRH.

NAGARAJ, N. (1999). Institutional management regimes for pricing of irrigation water: the French model - lessons for India. Agricultural Systems. v. 61, p. 191205.

PEARCE, D. W.; TURNER, R. K. (1990). Economics of natural resources and the environmental. Baltimore, Johns Hopkins University Press.

PIGRAM, J. J. (1992). Property rights and water markets in Austrália: an evolutionary process toward institutional reform. Water Resources Research, v. 29, n. 4, p.1313-1319, abr.

PIGRAM, J. J. (1998). Economic instruments in the management of Australia's water resources: a critical view. In: SIMPÓSIO INTERNACIONAL SOBRE GESTÃO DE RECURSOS HÍDRICOS. Gramado.

RIBEIRO, M. M. R.; LANNA, A. E. L. (1997). Bases para cobrança de água bruta: discussão de algumas experiências. In: SIMPÓSIO BRASILEIRO DE RECURSOS HÍDRICOS, 12., Vitória, 1997. Anais. Porto Alegre, ABRH.

RIGHETTO, G. M. (2001). Capacidade de pagamento e cobrança pelo uso e degradação dos recursos hídricos. São Carlos. 109p. Dissertação (Mestrado) Escola de Engenharia de São Carlos, Universidade de São Paulo.

RIOS, L. (1999). Distribuição espaço-temporal e balanço de massa do fósforo na represa de Salto Grande-Americana (SP). São Carlos. 159p. Tese (Doutorado) Escola de Engenharia de São Carlos, Universidade de São Paulo.

SACHS, I. (1986). Ecodesenvolvimento: crescer sem destruir. São Paulo, Vértice.

SACHS, I (1993). Estratégias de transição para o século XXI. Desenvolvimento e meio ambiente. São Paulo, Studio Nobel/Fundap. 
SÃO PAULO (1994). Estabelecimento de metas ambientais e reenquadramento dos corpos d'água: Bacia do Rio Piracicaba. São Paulo. Série de relatórios.

SERAGELDIN, I. (1994). Water supply, sanitation, and environmental sustainability: the financing challenge. Washington, World Bank.

SERAGELDIN, I. (1995). Toward sustainable management of water resources. Washington, World Bank.

SEROA DA MOTTA, R.; RUITENBEEK, J.; HUBER, R. (1996). Uso de instrumentos econômicos na gestão ambiental da América Latina e Caribe: lições e recomendações. Texto para discussão $n^{0}$ 440. Rio de Janeiro, IPEA.

SEROA DA MOTTA, R. (1998). Utilização de critérios econômicos para a valorização da água no Brasil. Texto para discussão $\mathrm{n}^{0}$ 556. Rio de Janeiro, IPEA.

SOUZA, M. P. (1995). A cobrança e a água como bem comum. Revista Brasileira de Engenharia-Caderno de Recursos Hídricos, v.13, n.1, p.25-55, Jun.

SOUZA, M. P. (2000). Instrumentos de gestão ambiental: fundamentos e prática. São Carlos, Riani Costa.

TEIXEIRA, D. (2000). Avaliação da qualidade da água e levantamento de custos de tratamento de efluentes visando a recuperação de um sistema eutrofizado (Represa de Salto Grande - Americana/SP). São Carlos. 182p. Tese (Doutorado) - Escola de Engenharia de São Carlos, Universidade de São Paulo.

TEXEIRA, F. J. C.; SOUZA FILHO, F. A.; GOUVEIA, S. X. (1999). Gerenciamento dos recursos hídricos no Ceará (CD ROM). In: SIMPÓSIO BRASILEIRO DE RECURSOS HÍDRICOS, 13., Belo Horizonte, 1999. Anais. Belo Horizonte, ABRH.

TISDELL, C. (1993). Environmental economics: policies for environmental management and sustainable development. England, Edward Elgar. 
TORTAJADA, C. (1999). Legal and regulatory regime for water management in Mexico and its possible use in other Latin American countries. Water International, v.24, n.04, p.316-322, dez.

ZABEL, T.; REES, Y.; ANDREWS, K. (1999). Economic and financial aspects of water policies in selected european coutries. In: SEMANA INTERNACIONAL DE ESTUDOS SOBRE GESTÃO DE RECURSOS HÍDRICOS. Foz do Iguaçu, ABRH.

ZABEL, T.; REES, Y. (1999). Institutional framework for water management in the United Kingdom. In: SEMANA INTERNACIONAL DE ESTUDOS SOBRE GESTÃO DE RECURSOS HÍDRICOS. Foz do Iguaçu, ABRH. 